\title{
ANÁLISE GENÉTICA, CITOLÓGICA E MOLECULAR DE MUTANTES QUE AFETAM A MORFOGÊNESE EM Aspergillus nidulans
}

\author{
RENATA CASTIGLIONI PASCON \\ Bióloga
}

Orientadora: Profa. Dra. ALINE APARECIDA PIZZIRANI-KLEINER

Tese apresentada à Escola Superior de Agricultura "Luiz de Queiroz", Universidade de São Paulo, para obtenção do título de Doutor em Agronomia, Área de Concentração: Genética e Melhoramento de Plantas.

$P \mid R A C I C A B A$

Estado de São Paulo - Brasil

Outubro - 1998 
Dados Internacionais de Catalogação na Publicação (CIP) DIVISĀO DE BIBLIOTECA E DOCUMENTAÇĀO - Campus "Luiz de QUeiroz"/USP

\author{
Pascon, Renata Castiglioni \\ Análise genética, citológica e molecular de mutantes que afetam a morfogênese \\ em Aspergillus nidulans / Renata Castiglioni Pascon. - - Piracicaba, 1998.
}

$132 \mathrm{p}$.

Tese (doutorado) - E Escola Superior de Agricultura Luiz de Queiroz, 1998. Bibliografia.

1. Aspergilo 2. Divisão celular 3. Genética do desenvolvimento 4. Mutação 5. Sequência de nucleotideo 6 . Transformação genética I. Título 
“... a única coisa requerida dos Filósofos e dos Cientistas, é a capacidade de contemplar a natureza ..." 


\section{À memória de meu pai Geraldo Pascon, À minha mãe Dayse Castiglioni Pascon e ao meu irmão Luciano Castiglioni Pascon}

Dedico

Ao meu marido Marcelo A. Vallim

Ofereço 
Agradeço especialmente ao Dr. Marcelo A. Vallim, pela sua contribuição, fundamental à execução deste trabalho. 


\section{Agradecimentos}

À minha orientadora Prof. Dra. Aline Aparecida Pizzirani-Kleiner, por sua orientação, apoio e amizade durante o meu curso de Pós-Graduação.

To my Major Professor, Dr. Bruce Miller, for his perfect advisement, for the enormous contribuiton given to my education, to this work, and specially for the oportunity to learn, that was given to me, by him. I also acknowledge his great friendship.

To the Research Assistante, Karen Y. Miller, for my trainning in Molecular Biology techniques, for the technical and scientific support given to the projects developed by me in Dr. Miller's laboratory, and also for her great friendship.

To the Post-Doctoral Fellows at Dr. Miller's laboratory Dr. James Dutton and Dr. Marcelo A. Vallim, for their contribuitions during the course of this work.

Ao José Antonio da Silva, pelo apoio técnico, por sua colaboração e amizade durante a minha estada no Laboratório de Genética de Microrganismos da ESALQ/USP.

Aos colegas do Laboratório de Genética de Microrganismos, Alexandre, João Pamphile, Adriana, Wellington, André, Rosemeire, Luciana Ribeiro, Luciana Regitano, Carlos, Chirlei, Margarete, Iara, Maria Isabel e Maria Helena Fungaro.

To Dr. Claudio Costa, who I will always acknowledge for showing me the doorway to Science. 
À Dra. Marisa Vieira de Queiróz pela sua colaboração, amizade e apoio incondicional em todos os momentos.

Ao Dr. Gustavo H. Goldman pela ajuda, sugestões, e amizade.

To Dr. Alan Caplan for his friendship, and also for introducing me to Dr. Bruce Miller.

À Léia, pelos serviços prestados na secretaria da Pós-Graduação, pela amizade e agradável convivência

À Bete e Silvana pelos serviços prestados na Biblioteca do Departamento de Genética da ESALQ/USP e pela amizade.

À Carmem M. S. F. Pilotto pelo auxílio e pelos bons momentos que passamos juntas.

Ao Corpo Docente do Departamento de Genética.

Aos colegas do Departamento de Genética.

Aos meus queridos amigos, inesquecíveis ... Adriana, Sônia, Peri, Mônica, Nirlei, Salete, Silvia, Gildinha, Andrézinho, Wellington, João, Marisa e Luizão.

Aos meus amigos Lindalva, Divino, Mandela e Naiara, pela alegria que sempre me trouxeram, fazendo com que estivessemos mais perto do Brasil durante estes dois anos e seis meses.

A Família Vallim pela acolhida. 
Ao CNPq e a CAPES pela bolsa de Doutorado no país.

To the NSF (National Science Foundation) for funding my trainning and the projects developed in this work.

To the Department of Microbiology, Molecular Biology and Biochemistry, University of Idaho.

À todos os que contribuíram direta ou indiretamente para a realização deste trabalho.

À Deus. 


\section{SUMÁRIO}

Página

LISTA DE FIGURAS ............................................... xiv

LISTA DE TABELAS ............................................... xvi

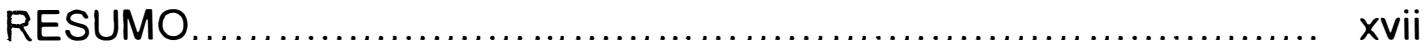

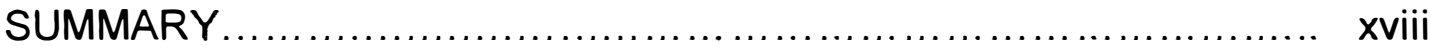

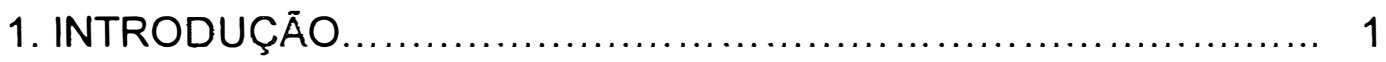

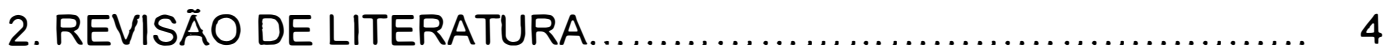

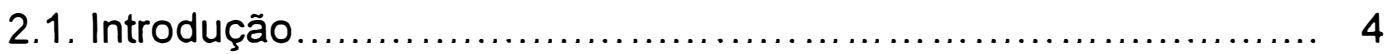

2.2. Características gerais do modelo biológico Aspergillus nidulans... 4

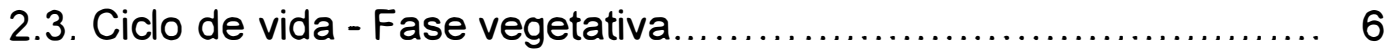

2.3.1. Germinação e polarização do crescimento da hifa............... 6

2.3.2. Septação e citocinese ....................................... 9

2.3.3. Mutantes para o ciclo celular............................... 11

2.4. Aquisição de competência para o desenvolvimento do conidióforo ..................................................... 23

2.5. Ciclo de vida - Reprodução assexual.......................... 25

2.5.1. Regulação gênica do desenvolvimento do conidióforo............ 27

2.5.2. Mutantes "Fluffy" .......................................... 33

2.6. Ciclo de vida - Reprodução Sexual.............................. 40

2.7. Objetivos................................................. 43

3. MATERIAIS E MÉTODOS .................................. 45

3.1. Linhagens de Escherichia coli................................ 45

3.2. Linhagens de A. nidulans.................................. 45

3.3. Meios de cultura ............................................... 46

3.3.1. Meio LB (Luria-Bertani) ..................................... 46

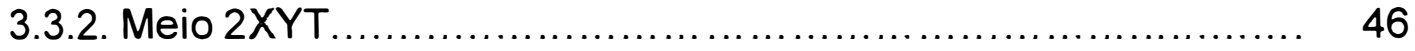

3.3.3. Meio TB.................................................. 46

3.3.4. Meio NCZYM.......................................... 46 


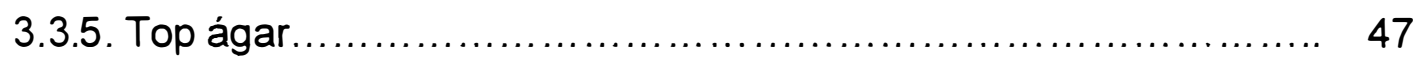

3.3.6. Meio Completo para A. nidulans (YG-MTV) ................... 47

3.3.7. Meio Minimo para A. nidulans (MM) ......................... 47

3.4. Soluções e Tampões......................................... 47

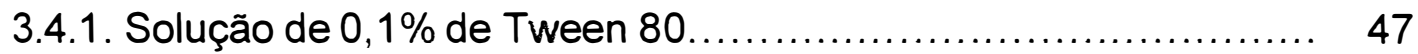

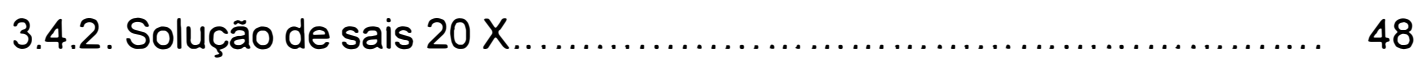

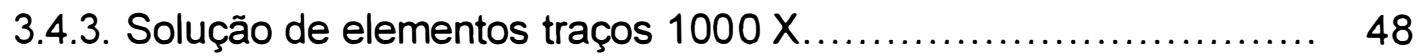

3.4.4. Solução de vitaminas (Käfer, 1977) .......................... 48

3.4.5. Soluções de requisitos nutricionais (Käfer, 1977)................ 49

3.4.6. Tampão TE ............................................... 50

3.4.7. Tampão de corrida TBE 10X .............................. 50

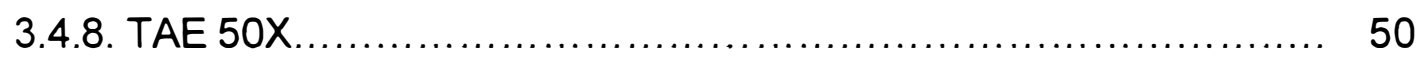

3.4.9. Tampão de amostra para eletroforese de DNA .................. 50

3.4.10. Solução de fenol estabilizada.................................. 51

3.4.11. Solução estoque de RNAse ................................. 51

3.4.12. Solução de TELS 20 X................................... 51

3.4.13. Solução X-Gal (5-bromo-4-chloro-3-indolyl- $\beta$-D-galactoside)..... 51

3.4.14. Solução de IPTG Sigma (Isopropil $\beta$-D-tiogalactopiranoside)..... 51

3.4.15. Solução de Brometo de Etídeo................................. 52

3.4.16. Tampão de extração de DNA total de fungos filamentos.......... 52

3.4.17. Tampão EB para extração de RNA ............................ 52

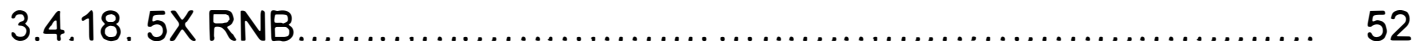

3.4.19. Solução I para extração de DNA plasmidial....................... 52

3.4.20. Solução II para extração de DNA plasmidial...................... 53

3.4.21. Solução Ill para extração de DNA plasmidial...................... 53

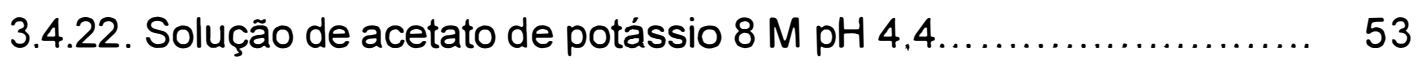

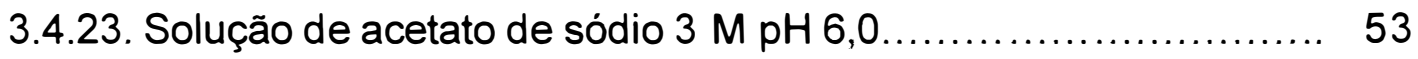

3.4.24. Tampão TM para eluição de bacteriófago $\lambda \ldots \ldots \ldots \ldots \ldots \ldots \ldots . . \ldots . \ldots 5$

3.4.25. Tampão de ativação para extração de DNA de bacteriófago $\lambda \ldots 53$ 


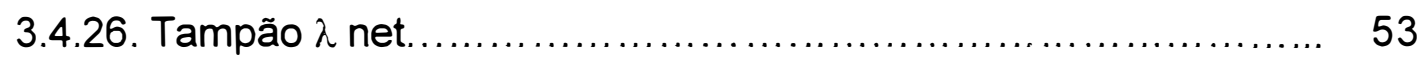

3.4.27. Solução de Denaturação..................................... 54

3.4.28. Solução de Neutralização...................................... 54

3.4.29. 20X SSC ................................................ 54

3.4.30. Tampão MOPS 10X para "Northern Blot"...................... 54

3.4.31. Tampão de amostra para RNA ............................ 54

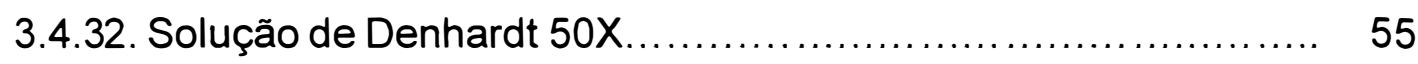

3.4.33. Solução de hibridização para membrana de Nylon................ 55

3.4.34. Solução de hibridização TNSD para membrana de nitrocelulose 55

3.4.35. Meio Osmótico.......................................... 55

3.4.36. Solução de equilíbrio dos protoplastos.......................... 55

3.4.37. Tampão STC ............................................. 56

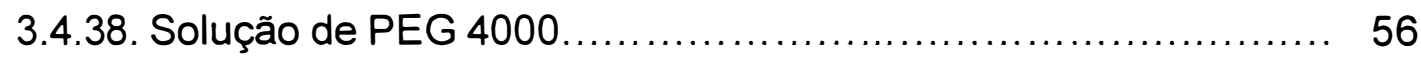

3.4.39. Meio YGS................................................... 56

3.4.40. Solução de fixação......................................... 56

3.4.41. Solução estoque de DAPI (4,6-diamino-2-phenilindol)............ 56

3.4.42. Solução estoque de Calcofluor............................... 57

3.4.43. Solução de montagem de lâminas............................ 57

3.4.44. Solução de Tiabendazol........................................ 57

3.4.45. Solução de Nocodazol......................................... 57

3.5. Extração de DNA cromossomal de fungo filamentoso................ 57

3.6. Extração de RNA de cultura vegetativa em diferentes tempos do desenvolvimento.................................................. 58

3.7. Técnica de "Southern Blot" (Sambrook et al., 1989)................. 59

3.8. Técnica de "Northern Blot" (Sambrook et al., 1989)................. 60

3.9. Extração em pequena escala de DNA Plasmidial de E.coli.......... 60

3.10. Extração de DNA plasmidial em larga escala de E. coli........... 61

3.11. Purificação de DNA plasmidial em gradiente de $\mathrm{CsCl}_{2}$ (Sambrook, et al, 1989........................................... 62 
3.12. Células competentes para transformação de E.coli.............. 63

3.13. Transformação de E. coli...................................... 63

3.14. Empacotamento de cosmídio................................. 64

3.15. Transfecção de células de E. coli por cosmídios empacotados... 64

3.16. Preparo de células de $E$. coli para transfecção e lise por bacteriófago $\lambda$ gt10 ............................................... 65

3.17. Transfecção e lise de células por bacteriófago $\lambda$ gt10............ 65

3.18. Imobilização de placas de lise em suporte sólido................. 65

3.19. Hibridização de placas de lise fixadas em membrana de nitrocelulose ........................................................ 66

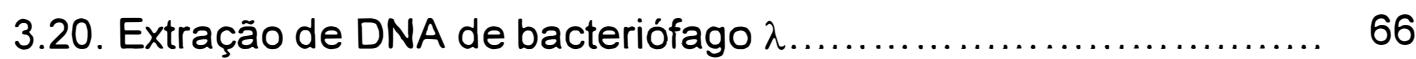

3.21. Marcação de sonda radioativa................................... 67

3.22. Síntese de cDNA para sonda radioativa........................ 67

3.23. Obtenção de protoplastos de A. nidulans........................ 68

3.24. Transformação de A. nidulans.................................. 69

3.25. Coloração de núcleos e de parece celular com corantes fluorescentes.................................................... 69

3.26. Análise de heterocários .................................... 70

3.27. Sequenciamento de nucleotídeos........................... 70

3.28. Técnica fotográfica e edição das micrografias.................... 70

4. RESULTADOS E DISCUSSÃO .................................. 71

4.1. Estudo do mutante binucleado, bncA1 ......................... 71

4.1.1. Análise da germinação e cinética de divisão nuclear............ 71

4.1.2. Análise dos elementos internos da hifa........................ 75

4.1.3. Estudo da sensibilidade à drogas antimicrotúbulos.............. 77

4.1.4. Análise dos efeitos da mutação bncA1 no conidióforo............ 79

4.1.5. Análise da frequência de heterocários e de diplóides da linhagem bncA1 ................................................ 81

4.1.6. O gene bncA e a progressão do ciclo celular................... 83 
4.2. Estudo do mutante aconidial aco586 ........................ 88

4.2.1. Clonagem e caracterização do gene aco586 .................. 88

4.2.2. Caracterização física do gene $a c 0586 \ldots \ldots \ldots \ldots \ldots \ldots \ldots \ldots . . \ldots 2$

4.2.3. A deleção do gene aconidial aco586 ......................... 96

4.2.4. Os efetios da inativação do gene aco586 na conidiogênese..... 99

4.2.5. Os efeitos da inativação gênica durante a germinação do conídio........................................................... 103

4.2.6. Os efeitos da inativação de aco586 na morfogênese da hifa vegetativa e do conidióforo......................................... 103

4.2.7. O gene aco586 e o seu papel na morfogênese de A. nidulans... 109 5. CONCLUSÕES ............................................. 113 ANEXO A .......................................................... 114

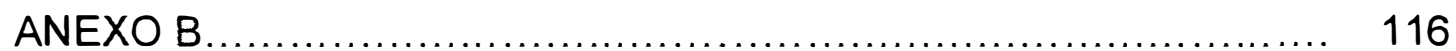

REFERÊNCIAS BIBLIOGRÁFICAS.............................. 118 APÊNDICE ...................................................... 131 


\section{LISTA DE FIGURAS}

Página

1. Linhagem selvagem UI 201 em diferentes tempos da germinação (A-D). Germinantes da linhagem mutante UI 203 (E-I). Os tempos estão indicados na margem direita. As setas apontam os septos, e as setas duplas os núcleos em mitose. Os aumentos são de 400X para $A, E, F, G, H$ e I. Para as micrografias $B, C, D$, o aumento é de 630X.. 73 2. Cinética de divisão nuclear para a UI 201 (selvagem) e UI 203 (bncA1). Cada ponto do gráfico representa o número médio de núcleos por germinantes para um dado tempo, em cada linhagem. Foram analisados cerca de 200 germinantes para cada tempo......... 74

3. A e B são compartimentos da hifa da linhagem mutante UI 203. A micrografia $C$ exemplifica elementos internos da da linhagem selvagem UI 201. Aumentos são de 400X para A e C e 630X para B. As setas apontam os septos $e$ as setas duplas os núcleos fragmentados

4. Micrografia A, conidióforo do mutante bncA1, linhagem UI 203. Coloração dupla com DAPI/Calcofluor. Micrografia B, DIC ("differential interference contrast"). As setas indicam os septos. Aumento de $630 \mathrm{X}$

5. (A) mapa de restrição do cosmídio cos586.3. (1) fragmentos genômicos que complementam a mutação termossensivel aco586. (2) fragmentos usados como sonda em análise de "Northern Blot". + e - significa presença ou ausência de complementação da mutação no painel (1), e presença ou ausência da banda de $\sim 6,0 \mathrm{~Kb}$ no painel (2). Análise da expressão do mRNA do gene aco586 (B) e $\operatorname{argB}(C)$ por "Northern Blot".

6. Identidade entre os resíduos de aminoácidos da região que define o domínio de transativação ("Bbox"), da família de fatores de 
transcrição E/CBP. A.n.:Aspergillus nidulans; R.c.: Rana castebeiana; H.s. Homo sapiens. Os números à esquerda representam a posição dos aminoácidos na seqüência.

7. Representação esquemática da inativação gênica do gene aco586. (A) fragmento genômico EcoRI de 6,7 Kb. (B) plasmídio pFSB contendo o cDNA interrompido por $\arg B$. (C) integração do plasmídio pFSB no genoma por simples crossing-over. (D) troca gênica por duplo crossing-over entre o plasmídio pFSB e o locus aco586. Os sítios de restrição EcoRI em negrito são artificiais

8. Gráfico mostrando a cinética de produção de conídios das linhagens FGSC26 e $\Delta a c 0586.17$. As amostras para contagem dos conídios foram coletadas com $0,24,48,72,96,120$ e 144 horas após a inoculação

9. Micrografias da linhagem $\Delta a c 0586.17$. (A) e (B), conídios de tamanhos variados, DIC, aumento de 800X. (C), (D) e (E), representação da hifa vegetativa, DIC, aumento de 400X. (F) a (M), exemplos representativos da morfologia dos conidióforos da linhagem inativada, DIC, DAPI/Calcofluor. Aumentos de 400, 630 e 800X. A seta chama a atenção para a assincronia de brotamento da métula

10. Micrografias da linhagem selvagem FGSC26. A, cadeia de conídios, DIC, aumento de $800 \mathrm{X}$. B, hifa vegetativa com septos indicados por setas, DIC, aumento de 630X. C, D, E, e F, vários estágios de desenvolvimento do conidióforo, DIC, aumento de 400X, $630 \mathrm{X}$ e $800 \mathrm{X}$. G, H, e I, principais estágios de desenvolvimento do conidióforo, coloração com DAPI/calcofluor, microscopia de fluorencência, aumentos de 400X e 630X. 


\section{LISTA DE TABELAS}

Página

1. Teste de resistência ao Tiabendazol (A) e Nocodazol (B), para as linhagens selvagens (UI 202, UI 204), mutantes bncA1 (UI 203, UI 205), e diploides, heterozigoto (UI 212) e homozigoto bncA1 (UI 211). As medidas representam diâmetro das colônias, dado em milimetros. (N/C, não cresce)

2. Número de colônias heterocarióticas e diplóides originárias do cruzamento entre uma linhagem selvagem, UI 206 e mutante bncA1, UI 203

3. Quantificação dos conídios produzidos pela linhagem FGSC26 e $\triangle a c 0586.17$ em meio de cultura completo (YG) e em meio minimo (MM)

4. Viabilidade dos conidios da linhagem portadora da inativação do gene aco586 e da linhagem selvagem FGSC26. 


\title{
ANÁLISE GENÉTICA, CITOLÓGICA E MOLECULAR DE MUTANTES QUE AFETAM A MORFOGÊNESE EM Aspergillus nidulans
}

\author{
Autora: Renata Castiglioni Pascon \\ Orientadora: Aline Aparecida Pizzirani-Kleiner
}

Resumo

A pesquisa na área da morfogênese e ciclo celular do fungo filamentoso Aspergillus nidulans, começou a 30 anos atrás, a partir do isolamento dos mutantes que afetam o desenvolvimento do conidióforo e a progressão do ciclo celular. A análise molecular dos mutantes para a diferenciação do aparato assexual possibilitou o estabelecimento de uma via regulória do desenvolvimento que controla a organização espacial e temporal da célular-pé, da hifa aérea, da vesícula, da métula e da fiálide. Neste trabalho foram estudados dois genes que afetam a morfogênese e o ciclo celular em $A$. nidulans. Os resultados mostraram que o mutante bncA1 tem fenótipo distinto em todas as fases de vida do fungo, sendo importante desde a germinação do conídio até a diferenciação das estruturas reprodutivas assexuais, causando a formação de métulas e fiálides alongadas e multinucleadas. Este gene também exerce funções relevantes para o ciclo celular, uma vez que a mutação causa elevado índice mitótico, desintegração nuclear, e sensibilidade aos compostos que desestabilizam os microtúbulos. A segunda parte deste trabalho, apresenta a clonagem e o sequenciamento do gene aco586. Este, codifica um possivel fator de transcrição, o qual tem homologia com a família de ativadores da transcrição "CAAT enhancer binding protein" (E/CBP), a qual é conhecida por controlar a diferenciação celular em vertebrados. Mutações no gene aco586, causam a diminuição do desenvolvimento assexual e sexual. Além disso, os conidióforos possuem morfologia anormal, desenvolvimento lento e assincrônico. 
GENETICAL, CYTOLOGICAL AND MOLECULAR ANALYSIS OF MUTANTS WHICH AFFECT MORPHOGENESIS IN Aspergillus nidulans

\author{
Author: Renata Castiglioni Pascon \\ Adviser: Aline Aparecida Pizzirani-Kleiner
}

Summary

The research in the field of morphogenesis and cell cycle in the filamentous fungus Aspergillus nidulans started 30 years ago, with the identification of mutants that affect development of the conidiophore and cell cycle progression. The molecular analysis of the developmental mutants have established the developmental regulatory pathway which controls spatial and temporal organization of foot cell, aerial hyphae, vesicle, metulae and phialide. In this paper two genes that affect morphogenesis of the conidiophore, as well as cell cycle regulation, were studied in $A$. nidulans. The results showed that bncA1 mutant have a distinct phenotype in all stages of the life cycle of this fungus, since germination of the conidia through out reproductive cells, which present elongated and multinucleated metulae and phialide. This gene is also important for cell cycle regulation, since the mutation causes high mitotic index, nuclear disintegration and hypersensitivity to anti-microtubule compounds. The second part of this work, presents the cloning and sequencing of aco586. This gene encodes a putative transcription factor, that shares homology to the CAAT enhancer binding protein family (E/CBP), which are known to control cellular differentiation in vertebrates. Mutations in aco586 gene decreases asexual and sexual development. Moreover, conidiophores have abnormal morphology and development is delayed and asynchronous. 


\section{INTRODUÇÃO}

O envelhecimento celular e a transformação de células normais em células cancerosas são dois problemas que afetam diretamente a espécie humana. A compreensão dos mecanismos que dirigem estes dois fenômenos esbarra em dois tópicos estudados em Biologia, a diferenciação celular e o mecanismo de progressão do ciclo celular. A ciência aborda estes problemas estudando a expressão diferencial de genes, isto é, identificando e manipulando produtos gênicos que somente estão presentes em determinadas células e são capazes de modificar o padrão de regulação do ciclo celular (Jacobs, 1992; Hartwell \& Kastan, 1994; Nasmyth, 1995; Follette \& O'Farrell, 1997b).

Devido à complexidade deste assunto o conhecimento que se tem sobre ele é proveniente da compilação das informações obtidas dos estudos com modelos biológicos, como é o caso de, Xenopus leividans (Hair et al., 1998), Droshophila melanogaster (Follette \& O'Farrell, 1997a), Arabdopsis thaliana (Meyerowitz, 1997), Neurospora crassa (Springer, 1993), Saccharomyces cerevisiae e Schizzosaccharomyces pombe (Forsburg \& Nurse, 1991; Kron \& Gow, 1995). Estas duas leveduras e Aspergilllus nidulans marcaram profundamente o estudo da morfogênese e ciclo celular. Este fungo filamentoso se tornou um modelo para estudo da morfogênese em 1945, quando um grupo de geneticistas liderados por Pontecorvo procuravam um microrganismo apropriado "para a abordagem genética de certos problemas da organização espacial da célula" (Clutterbuck, 1974). 
O ciclo de vida de $A$. nidulans é marcado por quatro eventos importantes: a germinação do conídio uninucleado, seguido de um periodo de crescimento vegetativo com a proliferação da hifa miltinucleada durante o qual, as células adquirem competência para o desenvolvimento da reprodução assexual e sexual. O cumprimento destas etapas requer a transição entre 0 padrão de crescimento polarizado da hifa vegetativa para o crescimento apolar. Este evento ocorre por meio da organização espacial e temporal de vários tipos celulares diferenciados, como a célula-pé, a hifa aérea, a vesícula, a métula, a fiálide, e os conídios, os quais compõe o conidióforo, que é o aparato reprodutivo assexual (Clutterbuck, 1974). Para realizar este programa polimórfico, no qual se observa a ocorrência de tipos celulares diferenciados como, a formação do broto (correspondente ao conídio), da pseudo-hifa (esterigmas primários e secundários) e da hifa verdadeira, este fungo precisa coordenar o seu programa de desenvolvimento ao padrão adequado de regulação do ciclo celular.

Os estudos sobre mutantes que afetam a morfogênese do conidióforo e a progressão da mitose revelaram uma via regulatória que controla a conidiogênese e ampliaram os conhecimentos sobre o mecanismo universal de controle do ciclo celular (Clutterbuck, 1969; Morris, 1976; Timberlake, 1990; Miller, 1993; Mirabito \& Osmani, 1994; Osmani \& Ye, 1996; Harris, 1997; Adams et al., 1998)

Este trabalho de pesquisa tem por objetivo estudar os genes bncA e aco586, os quais afetam a morfogênese do conidióforo e a progressão do ciclo celular em $A$. nidulans. Serão testadas duas hipóteses, a primeira delas é que o gene bncA está envolvido na progressão do ciclo celular sendo esta a razão pela qual a mutação neste gene afeta a organização do conidióforo, modificando o padrão morfogenético neste fungo filamentoso. A segunda hipótese a ser testada é de que o gene aco586 controla importantes passos durante a morfogenese das estruturas reprodutivas assexuais e sexuais. A clonagem deste gene e a dedução da seqüência de aminoácidos codificada por 
ele permitirá conhecer de qual forma este gene atua para modificar o desenvolvimento em $A$. nidulans.

Finalmente, espera-se contribuir para o conhecimento na área de desenvolvimento e diferenciação celular. 


\section{REVISÃO DE LITERATURA}

\subsection{Introdução}

Atualmente uma das questões mais intrigantes em Biologia, refere-se a forma pela qual as células fazem o reconhecimento do meio em que se encontram, captando informações que são transmitidas e traduzidas para 0 ambiente intracelular causando uma resposta. A informação decodificada na "linguagem celular" culmina dentro do núcleo, ativando genes regulatórios e estruturais os quais irão modificar processos básicos como ciclo celular, morfogênese, e vias metabólicas alternativas adequando o organismo à condição ambiental detectada. Este mecanismo é conhecido como transdução de sinal.

Este texto pretende compilar e analisar algumas das informações disponiveis sobre os genes e as proteínas envolvidas no desenvolvimento e diferenciação celular e na regulação do ciclo mitótico e seu aparato, utilizando fungos como modelos biológicos. A harmonia entre estes dois processos é crucial para o sucesso celular e a perpetuação da espécie. Por este motivo a coordenação entre eles deve ser muito bem feita.

\subsection{Características gerais do modelo biológico Aspergillus nidulans}

O fungo $A$. nidulans é um ascomiceto filamentoso que possui uma fase vegetativa na qual há proliferação da hifa. Esta é uma célula tubular que cresce 
por extensão apical, coloniza o meio e forma um tecido vegetativo denominado micélio. $O$ organismo em questão se reproduz via ciclo assexual e sexual, produzindo conídios e ascósporos, sendo portanto classificado como um fungo perfeito (Clutterbuck, 1974).

A. nidulans tornou-se relevante como modelo biológico quando começou a ser estudado do ponto de vista genético por Pontecorvo em 1953. Um dos motivos da sua escolha por Pontecorvo foi a facilidade de isolamento e caracterização de mutantes morfológicos e auxotróficos, uma vez que este fungo tem conídios uninucleados e é haplóide. Um grande número de mutantes foi gerado na linhagem proveniente de Glasgow (Yuill, 1939). A distribuição das mutações ao longo dos 8 cromossomos, a descoberta do ciclo parassexual, e a existência do ciclo sexual possibilitaram o mapeamento das novas marcas genéticas (Roper, 1952). Os trabalhos de genética clássica realizados em $A$. nidulans são de um valor inestimável, tendo grande extensão e complexidade. Por este motivo, não serão abordados nesta revisão, pois seria necessário tratar o assunto com extrema profundidade para fazer justiça a sua importância, o que seria impossivel dentro deste contexto. Porém a compilação dos dados com os quais os mapas de ligação foram construído podem ser acessados via:

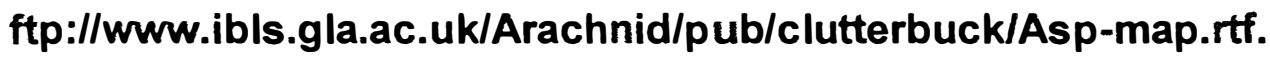

Atualmente o mapa genético de Aspergillus nidulans é bastante detalhado, sendo possivel mapear novos genes com boa precisão. Uma versão atualizada do mesmo pode ser diretamente acessada via http://www.kumc.edu/research/fgsc/asperg.html. Os oito grupos de ligação propostos inicialmente, foram confirmados por meio da separação de cromossomos (Brody \& Carbon, 1989). Existe também um mapa físico baseado em dois bancos de cosmídios ordenados (pWee e pLorist) (Xiong, 1996), os quais estão sendo seqüenciados em um projeto genoma. Em breve será possivel correlacionar o mapa genético ao mapa físico. Esta correlação será útil para a clonagem dos genes que não podem ser clonados pelo método 
tradicional de complementação de mutação, utilizando banco genômico. A correlação entre marcas genéticas e seqüências de DNA contidas nos cosmídios conhecidos tornará a técnica de "chromosome walking" viável para a clonagem dos genes que tem fenótipos sutis (Hamer, 1997).

Várias classes de mutantes foram isoladas no decorrer dos anos, dentre elas, mutantes auxotróficos (Roberts, 1959), para vias metabólicas (Arst \& MacDonald, 1973), para resistência à drogas (de Souza et al., 1998), e mutantes morfológicos. Esta última classe pode ser subdividida em mutantes para crescimento e ciclo celular (Morris, 1973), para aquisição de competência (Axelrod, 1972) e para morfogênese do conidióforo (Clutterbuck, 1969). No decorrer desta revisão será feita uma análise dos conhecimentos disponiveis sobre estes mutantes e sobre os processos biológicos onde os seus respectivos genes atuam. A divisão dos tópicos foi feita de tal forma, que a medida que se descreve os eventos que ocorrem nas diversas fases do ciclo de vida do fungo, há descrição também dos mutantes que afetam este determinado estágio do ciclo.

\subsection{Ciclo de vida - fase vegetativa}

\subsubsection{Germinação e polarização do crescimento da hifa}

O programa de desenvolvimento do fungo $A$. nidulans envolve a germinação do conídio, crescimento vegetativo, aquisição de competência, a passagem pelo ciclo assexual e finalmente quando este se completa, o fungo realiza o ciclo sexual (Axelrod et al., 1973; Clutterbuck, 1970; Clutterbuck, 1974; Clutterbuck, 1977; Timberlake, 1980; Timberlake, 1990; Miller, 1990; Money \& Yager, 1990; Champe \& Simon, 1992; Miller, 1993; Harris, 1997; Adams et al., 1998). 
A primeira parte deste programa inicia-se com o conídio, o qual é a estrutura reprodutiva assexual de $A$. nidulans, capaz de se manter dormente, porém viável por longos períodos de tempo. Quando em situação favorável de umidade, temperatura e nutrientes, este é capaz de germinar e reproduzir uma colônia com as mesmas propriedades daquela que the deu origem (Clutterbuck, 1974).

O primeiro passo em direção à germinação é a incorporação de água, fazendo com que haja expansão do conídio. Dentro de um período de aproximadamente 4 horas ocorre a primeira divisão mitótica, sendo este o tempo necessário para a quebra completa da dormência. Após 8 horas, o conteúdo citoplasmático aumenta em 10 vezes e o conteúdo de DNA aumenta em 8 vezes, ou seja, 3 divisões nucleares se completam sincronicamente (Fiddy \& Trinci, 1976). A partir da terceira divisão mitótica, há perda gradual da sincronização da divisão nuclear (Rosenberg \& Kessel, 1967).

Ocorrem também alterações morfogenéticas. $O$ conídio emite um tubo germinativo ao mesmo tempo em que a segunda divisão nuclear ocorre. Há o estabelecimento de um eixo de crescimento polarizado na ponta do tubo germinativo, fazendo com que a hifa cresça nesta direção pela deposição de parede celular (Gooday, 1983; Fiddy \& Trinci, 1976). Este processo é muito importante, se a parede celular não for corretamente formada há perda do crescimento polarizado (McGodrick et al.,1995). A remoção enzimática da parede leva a formação de protoplastos esféricos e perda do crescimento polarizado, porém se houver nova deposição de parede celular o eixo polarizado volta a se estabelecer (Doonan, 1992). Várias tentativas foram feitas para isolar mutantes que especificamente modificassem a polarização do crescimento da hifa. Mas a maioria destes mutantes afetam indiretamente a polarização, alterando a composição da parede celular e a estabilidade osmótica, ou por interferirem diretamente com o processo de divisão nuclear, como por exemplo é o caso do gene da calmodulina que afeta a divisão nuclear 
e consequentemente a polarização (Rasmussen et al., 1990). A interrupção do gene da $\beta$-tubulina ("gene disruption"), faz com que a hifa tenha crescimento lento e aberrante (Doshi et al., 1991).

Harris et al. (1994) utilizaram anticorpos monoclonais para identificar actina em $A$. nidulans. Esta proteina localiza-se na ponta da hifa em crescimento e também em pontos dispersos pelo citoplasma que são coincidentes com os pontos de deposição dos septos. Neste último caso a localização da actina é transitória, desaparecendo após a evidenciação do septo com calcofluor. Com este trabalho os referidos autores forneceram as primeiras evidências de um componente estrutural que direciona a polarização.

McGodrick et al. (1995) clonaram uma miosina de classe I, essencial em A. nidulans. Sob o controle de um promotor induzivel (alcA::myoA) este gene pode ter sua expressão manipulada. Niveis baixos de expressão causam o intumescimento do conídio, não sendo possivel realizar a extensão apical da hifa, e consequentemente a morte celular. A localização da proteina mostrou que esta é encontrada na região apical da hifa. Estes resultados indicam que a miosina I de $A$. nidulans estaria envolvida no processo de polarização do crescimento. Os autores levantam várias hipóteses para explicar a função de myoA, como por exemplo transporte de precursores da parede celular e da membrana, transporte de enzimas sintetizadas e/ou transporte de vesículas até a membrana plasmática.

Kruger \& Fisher (1998) descreveram a identificação de gene samB. A proteina codificada por este gene, aparentemente desempenha funções no processo de polarização. A deleção de samB em $A$. nidulans e também de seu homólogo em $S$. cerevisiae (mub1), provoca a ramificação prematura e excessiva da hifa, e a formação de múltiplos sítios de brotamento na levedura. Estes resultados indicam fortemente uma falha no controle espacial e temporal da seleção dos pólos de crescimento nestes organismos. 
Em S. pombe existem evidências sobre a polarização do crescimento. Mata \& Nurse (1997) detectaram que o produto do gene tea1 se localiza nas extremidades celulares desta levedura, a qual tem crescimento polarizado nas extremidades opostas do eixo maior. Estudos citológicos demonstraram que esta proteína co-localiza com a região por onde os microtúbulos crescem. Foi demonstrado neste trabalho que a depolimerização dos microtúbulos faz com que a proteina TEA1 passe a se localizar aleatoriamente. Não foi possivel relacionar a presença da actina com TEA1. O gene tea1 é considerado um importante marcador citoplasmático que sinaliza a direção em que o crescimento deve ocorrer.

\subsubsection{Septação e citocinese}

Vários autores, dentre eles mais recentemente Harris et al. (1994) e Wolkow et al. (1996), mostraram os eventos que ocorrem logo após a germinação do conídio uninucleado. Estes eventos refletem, em última análise, a coordenação existente entre mitose e citocinese.

De forma análoga, ao termo "ciclo celular" usado em células uninucleadas para descrever os eventos que compõe a divisão nuclear e celular, o termo "ciclo de duplicação" foi cunhado para descrever os mesmos eventos na hifa multinucleada (Fiddy \& Trinci, 1976). Segundo estes autores, as características de um "ciclo de duplicação" seriam os mesmas do ciclo celular, com a diferença que não há citocinese após cada divisão nuclear.

As primeiras observações microscópicas feitas em linhagens selvagens por Clutterbuck (1970) e Fiddy \& Trinci (1976), mostraram que somente depois que o tubo germinativo passa por três séries de divisões nucleares, e portanto possue oito núcleos distribuídos pela extensão de seu tubo germinativo, é que um septo é formado junto ao conídio, deixando pelo menos um núcleo dentro do mesmo. 
As experimentações de Harris et al. (1994) e Wolkow et al. (1996) com os vários mutantes termossensíveis para divisão nuclear, migração nuclear e septação (Morris, 1976), possibilitaram determinar que na realidade é necessário que um certo volume celular seja atingido para que a septação ocorra. Porém o volume celular crítico somente vai ser atingido se a célula sofrer pelo menos uma divisão mitótica. Em ambos os trabalhos os autores defendem a hipótese de que existe um inibidor da septação em altas concentrações no conídio, e que o aumento do volume celular dilui o mesmo até o ponto em que este não é mais capaz de inibir a septação e, consequentemente, a citocinese ocorre. Este momento coincide com a ocorrência da terceira divisão mitótica.

A medida que a hifa se expande na região apical os núcleos que ficam nos compartimentos distais entram em dormência, ou seja, não se dividem por mitose. Porém os núcleos presentes na ponta da hifa (cerca de 40) são mitoticamente ativos, continuando a se dividir de modo semi-sincrônico e a fazer parte de compartimentos septados (Rosenberg \& Kessel, 1967). Os núcleos presentes nos compartimentos distais, em número variável de dois a dez, eventualmente, podem voltar a se dividir para formar as ramificações laterais da hifa, mas primeiro é preciso que se estabeleça um polo de crescimento para que então os núcleos voltem a sofrer divisões mitóticas novamente. Nem todos os compartimentos serão ativados para se ramificarem, e não se sabe ao certo qual é o sinal que determina qual o compartimento selecionado (Timberlake, 1990).

A partir do momento em que o tubo germinativo se ramifica, a ponta da hifa deixa de ser o único sítio de crescimento polarizado e então o micélio passa a ter vários pontos de crescimento ativo, e a colônia vai adquirindo o seu aspecto circular quando crescida em placa de Petri.

O descomprometimento da divisão nuclear e da divisão celular, juntamente com o processo de crescimento polarizado, garantem que o tecido 
multicelular formado será composto de compartimentos filamentosos e multinucleados. Este padrão celular tem enorme valor adaptativo para o fungo, sendo que o micélio filamentoso tem grande poder invasivo o qual é capaz de explorar de maneira muito eficiente o meio em que se encontra (Harris, 1997).

\subsubsection{Mutantes para o ciclo celular}

Até os anos 70, as informações sobre cada uma das fases do ciclo de vida em $A$. nidulans foram basicamente de caráter observatório, e muito se aprendeu sobre a biologia do fungo. Porém, o grande avanço dos conhecimentos sobre a genética e a regulação do ciclo celular foi dado por Morris (1976). Este pesquisador isolou uma série de mutantes termossensiveis relacionados à diversos aspectos do ciclo celular deste fungo. Os mutantes foram classificados da seguinte forma: a) mutantes defeituosos no processo de citocinese, os quais foram designados mutantes para septação, ou "sep". b) mutantes denominados nud's ("nuclear distribution" ou distribuição nuclear), os quais impediam a distribuição nuclear dentro da hifa, sem contudo afetar a divisão nuclear. c) mutantes que afetavam a mitose em si, classe esta onde encontram-se os mutantes bim ("blocked in mitosis" ou bloqueados na mitose), e nim ("never in mitosis" ou nunca em mitose).

A análise do comportamento destes mutantes e a identificação dos respectivos genes contribuiu muito para o entendimento de processo básicos como a regulação da mitose, posicionamento nuclear na hifa e citocinese. Esta área tornou-se tão importante que hoje $A$. nidulans, juntamente com $S$. cerevisiae e $S$. pombe, são considerados os modelos biológicos que mais contribuíram para o entendimento do ciclo celular (Morris et al., 1989; Doonan, 1992; Morris \& Enos, 1992; Osmani \& Ye, 1996). 
a) Mutantes para septação

Morris (1976) inicialmente isolou 5 mutantes termossensiveis do tipo "sep". A análise do mutante termossensivel sepB3 (Morris, 1976) mostrou a incapacidade das células continuarem o crescimento além da terceira divisão nuclear, morrendo logo em seguida, justamente no momento da citocinese. Durante as divisões nucleares iniciais é possivel observar um atraso transitório da fase $M$ da mitose. $\dot{E}$ interessante notar que os núcleos assumem formato aberrante característico dos aneuplóides. Harris \& Hamer (1995), clonaram o gene sepB. O produto gênico tem homologia com a proteina CTF4 de $S$. cerevisiae, a qual está intimamente relacionada com metabolismo do DNA cromossômico. Os autores sugerem que o funcionamento incorreto de $\operatorname{sep} B$ poderia levar ao acúmulo de algum tipo especifico de dano cromossomal que não permitiria que as células completassem a citocinese.

A confirmação desta hipótese veio quando Harris \& Kraus (1998) provaram que várias outras perturbações do metabolismo do DNA cromossômico, como por exemplo tratamento com doses subletais de hidroxiuréia e diepoxioctano, levam ao mesmo tipo de bloqueio da septação causado pela mutação em sepB.

Harris et al. (1997) realizaram o estudo de outro mutante para septação, sepA. Este também apresenta incapacidade de formar septo e possui padrão anômalo de ramificação da hifa e do conidióforo durante o crescimento na temperatura restritiva $\left(42^{\circ} \mathrm{C}\right)$. Apresenta também aumento do diâmetro da hifa, tanto na temperatura restritiva quanto na temperatura permissiva. Estes autores demonstraram que quando o mutante cresce por um determinado tempo sob temperatura restritiva é incapaz de depor o septo, porém, quando a colônia é transferida para a temperatura permissiva os septos são rapidamente formados nas posições corretas. $\mathrm{Na}$ temperatura restritiva, o mutante é incapaz de formar 0 anel contrátil de actina na região onde o septo vai ser deposto. A 
clonagem e a caracterização do gene $\operatorname{sep} A$, demonstraram que a proteina codificada por ele pertence à família $\mathrm{FH} 1 / 2$, a qual possui membros conhecidos em S. cerevisiae (bni1), S. pombe (cdc12) e Drosophila diaphanous. Em todos os casos estas proteínas estão direta ou indiretamente envolvidas no processo de citocinese.

Recentemente Kaminskyj \& Hamer (1998), selecionaram 6 mutantes termossensiveis denominados hyp. Estes correspondem a 5 genes, não ligados, que apresentam defeitos para polarização do crescimento e septação, sem contudo, afetar divisão nuclear. A análise destes mutantes poderá esclarecer muitos aspectos sobre a citocinese.

b) Mutantes que afetam a distribuição nuclear na hifa (nud's)

A análise microscópica dos mutantes termossensiveis nud ("nuclear distribuition") feita por Morris (1976), demonstrou que os núcleos não migravam e assim não eram capazes de se distribuírem normalmente ao longo do tubo germinativo, contudo estas mutações não afetavam a mitose. Alguns destes mutantes e seus respectivos supressores foram estudados do ponto de vista genético e molecular.

Xiang et al. (1994), isolaram e caracterizaram o gene nudA. A mutação neste gene causa um bloqueio na distribuição dos núcleos ao longo do tubo germinativo, sendo que os mesmos ficam acumulados no conídio. Eventualmente, um núcleo quebra o bloqueio e migra, possibilitando o crescimento, no entanto, este é bastante lento. A dedução da sequência de aminoácidos mostrou que a proteína possui quatro sítios de ligação ao ATP, o que é diagnóstico da classe da cadeia pesada da dineína citoplasmática, a qual é uma proteina motora encontrada em todos os organismos, desde as levedura até os mamiferos. Esta proteína é composta de duas cadeias pesadas, três intermediárias e quatro cadeias leves, as quais formam um 
complexo capaz de se movimentar ao longo dos microtúbulos em direção à extremidade negativa. $O$ complexo formado pelas diversas cadeias da dineina tem papel no transporte de organelas membranosas (Hirokawa, 1998). A descoberta deste gene em $A$. nidulans caracterizou a dineina como principal motor celular encarregado da distribuição nuclear na hifa vegetativa.

Posteriormente, Xiang et al. (1994) deletaram o gene nudA e observaram o mesmo fenótipo apresentado pelo mutante termossensivel. Neste mesmo trabalho os autores utilizaram anticorpos monoclonais e localizaram a cadeia pesada da dineina na ponta do tubo germinativo. Os resultados sugerem que apesar da dineina ter papel central na migração nuclear em $A$. nidulans, ela não é a única forma que a célula possui de transportar núcleos uma vez que não causa letalidade. É possivel que haja uma proteina com função redundante que permita a quebra do bloqueio imposto pela ausência de nudA.

Efimov \& Morris (1998), isolaram uma série de mutantes letais sintéticos na tentativa de identificar a(s) proteina(s) que poderiam exercer funções semelhantes a cadeia pesada da dineina. Para tanto, construiram uma linhagem com uma única cópia de nudA, sob o controle do promotor da álcool desidrogenase e promoveram a irradiação da mesma. Selecionaram aqueles mutantes capazes de crescerem como se fossem selvagens sob condições de indução de nudA, mas que tivessem significante redução do crescimento sob repressão, exacerbando os efeitos da ausência da cadeia pesada da dineína. Usando este método detectou-se 19 mutações em nove genes diferentes. Dois destes, sldA e s/dB, apresentaram forte letalidade sintética com relação à nudA, e 6 deles, inclusive sldA e sldB, apresentaram o mesmo efeito com relação a quinesina mitótica (bimC). A clonagem e o seqüenciamento de s/dA e $s / d B$ mostraram que estes genes codificam proteinas quinases homólogas à BUB1 e BUB3 de S. cerevisiae. Estes dois produtos gênicos estão envolvidos na montagem das fibras do fuso mitótico. $O$ conhecimento destes homólogos 
em mamiferos possibilitou a localização de BUB1 e BUB3 no cinetocoro. As evidências indicam que bub1 e bub3 fazem o controle da ligação dos centrômeros com as fibras dos microtúbulos, e somente depois que todos os cromossomos estão devidamente atados é que estas duas proteínas sinalizam a continuidade do ciclo celular (Pennisi, 1998). O mecanismo pelo qual isso ocorre, assim como a interação entre estas proteinas e a cadeia pesada da dineína ainda não é conhecido.

Goldman \& Morris (1995), por outro lado, isolaram supressores extra gênicos de nudA. A seleção foi feita para os mutantes que contribuíssem para a melhora da distribuição nuclear na hifa vegetativa. Esta estratégia teve o objetivo de descobrir genes que interagem com a cadeia pesada da dineína. Esta análise mutacional identificou cinco genes que são capazes de restaurar o crescimento vegetativo na ausência de nudA.

Entre os mutantes para distribuição nuclear, estudados por Morris (1976), está nudC3, o qual apresenta incapacidade de distribuir seus núcleos. Há ocorrência de três divisões nucleares normais, porém os oito núcleos nunca chegam a serem distribuídos ao longo da hifa vegetativa (Morris, 1976). A clonagem e o mapeamento físico deste gene não veio a esclarecer qual seria o mecanismo pelo qual nudC age, uma vez que a sequência de aminácidos, possui homologia com proteinas que não tem função conhecida. Porém, a proteina parece bastante conservada, tendo homólogos em Drosophyla melanogaster, Caenorhabditis elegans e H. sapiens (Osmani et al., 1990).

A relação entre nudC e nudF foi estabelecida quando detectou-se que a ausência de nudC diminui a abundância da proteina nudF. Este resultado foi reproduzido até mesmo quando nudF se encontrava sob o controle do promotor da álcool desidrogenase (alcAp) em condições de indução. Esses dados sugerem que nudC regula nudF de forma pós-transcricional, elevando os niveis desta proteina. É possivel que estas duas proteinas façam parte de um 
complexo sendo que, quando NUDC não está presente, NUDF está sujeita a degradação (Xiang et al., 1995b).

Recentemente, Morris et al. (1997) iniciaram uma estratégia para identificar genes responsivos à indução por prolactina em cultura de células $T$ de rato. Nesta análise, os autores identificaram um clone denominado c15. 0 seqüenciamento do mesmo demonstrou identidade de $68 \%$ com nudC. Neste trabalho foi possivel provar que existe homologia funcional entre o clone c15 e nudC, sendo que c15 é capaz de complementar a mutação nudC3, e também de restaurar os niveis de nudF.

O gene nudC é essencial, porém, os efeitos de sua deleção podem ser remediado por meio do aumento da concentração osmótica no meio de cultura e também pela incubação à temperaturas bem mais baixas, como $18^{\circ} \mathrm{C}$ (Chiu et al., 1997) A análise de linhagens deletadas mostrou que os germinantes crescem de forma esférica, perdem o padrão de crescimento polarizado e sofrendo lise celular. No tipo selvagem a quitina se localiza predominantemente na ponta da hifa, e na linhagem $\Delta$ nudC esta substância tem ocorrência disseminada por toda a extensão da parede celular, sem um local de predominância. A utilização do anticorpo anti-actina evidenciou que a mesma fica localizada por toda a superfície celular na linhagem $\Delta n u d C$, ao contrário do selvagem onde a actina localiza-se na ponta da hifa e nas regiões de deposição do septo (Harris et al., 1994). Estes resultados sugerem que nudC afeta a composição da parede celular, mas não explicam precisamente como isso afeta a distribuição nuclear. Os autores sugerem que além da proteína NUDC ser necessária na composição da parede celular, ela também tem a função de localizar e estabelecer um sítio de ação para a dineina. A hipótese é que no mutante termossensivel apenas a função junto à dineína fica prejudicada por causa da mutação, sem contudo haver qualquer efeito sobre a composição da parede. 
Os mutantes nudF7 e nudF6 são alelos termossensiveis que afetam a movimentação nuclear. Foram inicialmente isolados por Morris (1976) e apresentaram as mesmas caracteristicas dos outros mutantes para distribuição nuclear. Posteriormente analisado do ponto de vista molecular por Xiang et al. (1995b), demonstrou ser homólogo ao gene humano Lis-1. Este gene é causador de uma sindrome designada "Miller-Dieker lissencephaly-1". A mutação em Lis-1 causa deficiência durante o desenvolvimento cerebral por falha na migração dos neurônios. Acredita-se que o direcionamento do neurônio inicia-se quando o núcleo se posiciona na direção em que o neurônio deve se locomover, portanto, sugerindo uma homologia funcional entre Lis-1 e nudF.

Um dos últimos mutantes para distribuição nuclear descritos foi nudG, comprovando-se que este gene codifica a cadeia leve da dineina (Beckwith et al., 1995).

O processo de migração nuclear requer três compentes básicos: um motor capaz de impulsionar o núcleo, um trilho onde o mesmo possa caminhar, e um componente "ligante" que possa fazer a conexão entre as partes deste aparato. $O$ estudo dos mutantes para migração nuclear em fungos ajudou no fornecimento de candidatos para desempenhar estes papéis. A dineína citoplasmática parece ser 0 motor celular. Os dados provenientes de $S$. cerevisiae indicam que os microtúbulos citoplasmáticos são fortes candidatos ao papel de trilho celular, e o complexo dinactínico serve os propósitos de agente ligante que mantém os diferentes componentes em contato (Xiang et al., 1995a). Muitos detalhes precisam ser adicionados a este modelo, porém o mesmo serve de espinha dorsal para este processo biológico. 
c) Mutantes para progressão do ciclo celular

Os eventos básicos que compõem o ciclo celular, isto é, a replicação do DNA cromossômico, a duplicação dos centríolos e a formação das fibras do fuso mitótico são conservados desde os fungos até os eucariotos superiores (Morris et al., 1989; Morris \& Enos, 1992; Doonan, 1992; Nasmyth, 1996; Lew \& Kornbluth, 1996; Osmani \& Ye, 1996). Partindo desta premissa, há duas décadas atrás, alguns cientistas previram que a análise genética e bioquímica de mutantes que afetassem a mitose em organismos simples, como por exemplo, os fungos, seriam de grande valia para a composição de um modelo universal para o funcionamento e a regulação do ciclo celular. Foi a partir desta idéia que Hartwell (1974), Nurse (1975) e Morris (1976) isolaram uma série de mutantes para a progressão do ciclo celular em $S$. cerevisiae, $S$. pombe e $A$. nidulans, respectivamente. Desta forma, um número grande de genes relacionados ao controle do ciclo celular foram descobertos em eucariotos superiores, graças ao conhecimento que se tem sobre a mitose em fungos (Hartwell \& Kastan, 1994).

Com relação ao conhecimento do ciclo celular em $A$. nidulans também teve grande valia o estudo realizado por Bergen \& Morris (1983). Neste trabalho os autores descreveram a cinética de divisão nuclear neste fungo. Ficou estabelecido que o ciclo celular, que ocorre durante a germinação do conídio, leva em torno de 75 a 120 minutos, dependendo das condições de crescimento. $\mathrm{Na}$ temperatura de $37^{\circ} \mathrm{C}$ a fase $\mathrm{M}$ (mitose) é muito rápida, em torno de 5 minutos. $\mathrm{G} 2$ leva cerca de 30 minutos, $S 25$ minutos e G1 em torno de 15 minutos.

Um dos primeiros eventos que ocorrem durante o ciclo de divisão nuclear é a duplicação da região organizadora do fuso mitótico (conhecida por SPB "spindle pole body"). Isso ocorre na intérfase, durante a fase $S$ do ciclo celular. Na metáfase os dois SPB migram para polos opostos tendo entre si um 
arranjo de microtúbulos. É nesta fase que o nucléolo torna-se menos distinto e desaparece. As imagens geradas por microscopia eletrônica sugerem que em fungos, apesar da membrana nuclear não desaparecer, ela se torna menos densa (Doonan, 1992).

A análise da regulação do ciclo celular utilizando $A$. nidulans foi iniciada por Morris (1976) a partir do isolamento dos mutantes termossensiveis, já anteriormente descritos de maneira resumida. A classificação dos mutantes em "nim" e "bim" foi feita com base no aspecto adquirido pelos núcleos quando corados por um corante com afinidade por ácido nucleico. Mutantes "nim" possuem núcleos que aparentam estar sempre em intérfase, isto é, a cromatina corada nas bordas e a região central descorada, correspondente ao nucléolo. Os mutantes "bim" foram assim classificados uma vez que seus núcleos apresentam, constantemente, um aspecto mitótico, ou seja, sempre condensado, como um pequeno ponto luminoso no interior da hifa (Morris, 1976).

A medida que a análise bioquímica sobre os mutantes "bim" e "nim" foi se aprofundando ficou cada vez mais claro que a regra da universalidade do mecanismo de regulação do ciclo celular pode ser confirmada para o fungo filamentoso $A$. nidulans. Os principais componentes regulatórios da mitose são conservados neste fungo. $A$ atenção tem sido voltada, principalmente para uma classe de proteinas denominadas "quinase-dependente-de-ciclina" (cdk). Estas proteinas são chaves para a replicação do DNA, iniciação da mitose, formação do complexo promotor da anáfase e citocinese (Lew \& Kornbluth, 1996; Nasmyth, 1996).

A clonagem de $\operatorname{nim} X^{p 34}$ caracterizou em $A$. nidulans uma das principais proteinas quinase que estabelece que o ciclo celular deve cruzar a fronteira entre G1/S e G2/M (Osmani et al., 1994). Esta proteina quinase, a qual tem a histona $\mathrm{H} 1$ como principal substrato de fosforilação, foi primeiramente descrita em S. cerevisiae, mas é ubíqua em eucariotos. nim $X^{p 34}$ faz parte de um 
complexo denominado "cdK" ("cyclin dependent kinase") que para ser ativado deve estar ligado a uma ciclina (nimE ${ }^{\text {coc13 }}$ ). Mesmo que o complexo cdk seja formado, somente será ativado causando a progressão do ciclo celular quando a Tirosina-15 da proteína p34 for defosforilada por ação de uma proteína fosfatase codificada pelo gene $n i m T^{\text {cdc25 }}$ (O'Connell et al., 1992). Em levedura de brotamento foi possivel estabelecer que a passagem de $\mathrm{G} 1$ para $\mathrm{S}$ depende da complexão de p34 com a ciclina-G1 e que a passagem de $G 2$ para $M$ depende da ligação de p34 com um outro tipo de ciclina, denominada ciclina-B (Jacobs, 1992; Hartwell \& Kastan, 1994; Kock \& Nasmyth, 1994; Lew \& Kornbluth, 1996). Em A. nidulans só uma ciclina é conhecida, nim $\mathrm{E}^{\text {ciclina-B }}$, mas é provável que p34 associe-se à outros parceiros para promover as transições entre G1/S e G2/M (O'Connell et al., 1992; Osmani \& Ye, 1996). Para que haja saída da mitose, isto é, para que a anáfase se complete, é necessário que haja quebra do complexo cdk, por meio da degradação da ciclina-B. Acredita-se que - complexo promotor da anáfase, ou ciclossomo, seja responsável pela ubiquitinação da ciclina-B, caracterizando esta proteína como alvo de proteólise (Osmani \& Ye, 1996).

NIMT não é a única fosfatase envolvida na progressão do ciclo celular em $A$. nidulans, o gene bim $G$ também codifica uma fosfatase especifica da mitose, a inativação da mesma impede que as células deixem os estágios mais tardios da mitose. A sequência de aminoácidos de BIMG mostrou homologia com uma proteina fosfatase (PP1) de mamiferos e de $S$. cerevisiae, as quais são essenciais para o sucesso da mitose (Doonan \& Morris, 1989; Doonan et al., 1991).

Uma das descobertas mais notáveis sobre o funcionamento do ciclo celular ocorreu em A. nidulans quando Osmani et al (1987) clonaram nimA, o qual é o fundador de uma família gênica encontrada desde levedura até mamiferos. Este gene codifica uma proteina quinase do tipo Serina/Treonina. A princípio, ficou estabelecido que nimA funciona especificamente na progressão 
entre as fases $\mathrm{G} 2$ e $\mathrm{M}$, sua atividade fosforilativa, bem como o acúmulo de seu mRNA, começam a elevar-se em $\mathrm{G} 1$, $S$ e tem seu pico em $\mathrm{G} 2$, ao contrário de p34 que possui niveis constantes tanto de seu mRNA quando da proteína durante todo o ciclo celular. Durante a mitose os niveis de nimA começam a decair, e para que haja citocinese ela tem que ser abolida. As análises citológicas de mutantes nimA, demonstraram que durante o crescimento na temperatura restritiva não há desorganização dos microtúbulos citoplasmáticos, não há condensação da cromatina, e também não há formação do fuso mitótico. Portanto, a atividade da proteína NIMA é requerida para iniciar todos os aspectos da divisão nuclear (Osmani et al., 1991; Pu \& Osmani, 1995).

A atividade fosforilativa da proteína NIMA não depende somente do acúmulo da mesma durante as diferentes fases do ciclo celular, mas também é dependente do seu próprio estado de fosforilação. A análise da sequência de aminoácidos comprovou que NIMA possui um domínio de auto-fosforilação típico das proteínas quinases dependentes de CAMP. A mutação sítio específica desta região aboliu completamente a capacidade de autofosforilação de NIMA (Ye et al., 1995).

Ye et al. (1995) estudaram as possiveis interações entre nim $\mathrm{X}^{\mathrm{p} 34}$ e nimA. Chegaram a conclusão que a abolição da atividade da proteina p34 pela inativação de nimT não é suficiente para evitar o acúmulo da proteína NIMA na sua forma ativa. Porém, a inativação direta de p34 não só bloqueia o ciclo celular em G1 e G2, como também previne o acúmulo de NIMA. Por outro lado, - bloqueio do ciclo celular em G2 pela perda da atividade de NIMA não previne o acúmulo de p34 na sua forma ativa, porém em nenhum dos casos há progressão do ciclo celular, indicando que tanto $\operatorname{nimA}$ quanto $\operatorname{nim} \mathrm{X}^{\mathrm{p} 34}$ são igualmente necessários para o sucesso completo da mitose. (Osmani \& Ye, 1996).

Um outro complexo protéico que regula a progressão do ciclo celular é designado APC/C (complexo promotor da anáfase/ciclossomo). É composto por 
pelo menos oito polipeptídeos e dentre as várias funções que este complexo pode exercer, duas são bem conhecidas em S. cerevisiae. A primeira é a proteólise da ciclina-B durante a telófase e consequente finalização da mitose. A segunda é em $\mathrm{G} 1$, quando a função deste complexo é impedir a iniciação precoce da sintese de DNA (Zacharia \& Nasmyth, 1996; Irniger \& Nasmyth, 1997). Em A. nidulans nenhuma destas funções puderam ainda ser provadas, porém dos oito polipeptídeos que supostamente compõem o complexo, dois são bem conhecidos, bimA e bimE (Engle et al., 1990; O'Donnell et al., 1991). bimA é homólogo a APC3 ou nuc2 de S. cerevisiae, o qual está envolvido com a citocinese e bimE é homólogo de APC 1 ou cut4, os quais estão envolvidos em garantir o vínculo entre mitose e citocinese. Tanto bimA quanto bimE apresentam bloqueio para terminação da fase $M$ do ciclo celular, permanecendo com os núcleos condensados indefinidamente quando em temperatura restritiva. A mutação bimA ${ }^{A P C 3}$ é capaz de superar parcialmente 0 bloqueio imposto pela mutação em nimA, sendo que o duplo mutante é capaz de realizar a condensação da cromatina e organizar as fibras do fuso. Estes resultados indicam que nimA e bimA agem em conjunto, direta ou indiretamente, controlando a passagem por $G 2$, o que é um resultado inesperado, uma vez que acreditava-se que o complexo APC/C tivesse função apenas a partir da metáfase, finalizando a mitose (Lies et al., 1998).

Até $\bigcirc$ momento foi feita a análise dos principais componentes regulatórios do ciclo celular. Cabe fazer referência aos componentes estruturais da mitose. A maior parte destes genes foram isolados a partir de mutantes, como é o caso de gene benA, o qual foi isolado a partir de um mutante resistente à droga anti-microtúbulo benomil (Dekker \& Davidse, 1975). Posteriormente, foi estabelecido que benA codifica os isotipos $\beta 1$ e $\beta 2$ da $\beta$ tubulina. Um terceiro isotipo foi identificado como $\beta 3$, o qual é codificado por outro gene tubC (May et al., 1985; May et al., 1987; May \& Morris, 1988). Existem dois genes para $\alpha$-tubulina, tubA e tubB. O primeiro é componente dos 
microtúbulos presentes durante 0 crescimento vegetativo e $\circ$ segundo desempenha funções durante a meiose (Doshi et al., 1991; Kirk \& Morris, 1991).

Mais uma descoberta notável em $A$. nidulans foi a identificação da $\gamma$ tubulina (Oakley \& Oakley, 1989), a qual foi descoberta em uma análise mutacional em busca de supressores de benA, sendo o mutante supressor designado mipA (Weil et al., 1986). A clonagem e a caracterização física de mipA possibilitaram localizar a $\gamma$-tubulina na região organizadora do centriolo, e portanto não é um componente dos microtúbulos. Porém a deleção de mipA impede a formação, tanto de microtúbulos citoplasmáticos quanto mitóticos, sugerindo que apesar da $\gamma$-tubulina não fazer parte da estrutura microtubular, ela é requerida para iniciar a polimerização dos microtúbulos (Oakley et al., 1990).

O mutante bimC foi isolado por Morris (1976). A análise do fenótipo do mutante mostrou que o centriolo ("spidle pole body") divide-se, mas não se separa, gerando uma estrutura unipolar que não é capaz de segregar os cromossomos. A clonagem e o mapeamento físico mostraram que a proteina BIMC tem homologia de sequência com as proteinas da familia das quinesinas, as quais estão envolvidas com $\circ$ transporte de vesículas membranosas. A homologia se restringe a $42 \%$ na região motora. Apesar da similaridade de sequência, a quinesina BIMC não exerce a mesma função, sendo requerida durante a mitose (Enos \& Morris, 1990; Enos et al., 1991).

2.4. Aquisição de competência para o desenvolvimento do conidióforo

Uma vez que se estabelece o crescimento polarizado da hifa e suas ramificações, esta começa a colonizar o substrato formando o tecido vegetativo conhecido como micélio. 
Em condições normais de crescimento à $37^{\circ} \mathrm{C}$, em meio rico em cultura submersa, uma linhagem selvagem é capaz de permanecer indefinidamente em estágio de cultura vegetativa. Porém, se o micélio for exposto à uma superfície aerada, o que é conhecido por indução, há diferenciação do tecido vegetativo e uma série de eventos morfogenéticos levam ao desenvolvimento do conidióforo (Timberlake, 1990).

Os eventos fisiológicos que tomam parte durante a aquisição de competência são muito pouco conhecidos. Clutterbuck (1977) detectou uma queda substancial nos niveis de 3',5'-AMP cíclico juntamente com o tempo de aquisição de competência, mas este tópico não foi mais estudado.

Axelrod et al. (1973), determinaram o tempo de competência necessário para que uma cultura vegetativa de $A$. nidulans seja capaz de se diferenciar em reprodutiva. Pelos dados destes autores, o tempo de aquisição de competência é de 25 horas. Mesmo que a indução seja feita antes deste período as células não possuem a capacidade de diferenciação. Sob o aspecto fisiológico, o processo de diferenciação requer grande consumo de energia pela célula, a qual necessita de grande quantidade de massa para desenvolver 0 aparato reprodutivo, portanto, o tempo de aquisição de competência serviria para que as células pudessem acumular todos os componentes estruturais necessários para desempenhar a função reprodutiva. Do ponto de vista genético, o tempo de competência seria necessário para a ativação temporal e espacial correta dos genes que controlam e participam deste processo.

Pastushok \& Axelrod, (1976) demonstraram que diferentes fontes de nitrogênio e concentrações variadas de glicose não afetam o tempo de aquisição de competência. Os experimentos realizados deixam claro que o programa de desenvolvimento das estruturas de reprodução assexual não depende da exaustão de nutrientes do meio de cultura. Esta constatação mostrou que o desenvolvimento é geneticamente programado como parte do ciclo de vida deste fungo. 
Butnick et al. (1984a, 1984b) isolaram uma série de mutantes termossensiveis, dentre os quais três apresentaram bloqueios específicos da fase de pré-competência. As análises de alternância de temperatura mostraram que os produtos destes genes são necessários durante 0 crescimento submerso, sendo que todos os três mutantes foram incapazes de desempenharem o ciclo assexual e sexual corretamente (Yager et al., 1982).

Os mecanismos genéticos que coordenam a aquisição de competência são muito pouco conhecidos. Este processo representa um tópico de grande relevância, uma vez que todas as células que se diferenciam dependem de tal mecanismo, sendo um evento indispensável para a adaptação e sobrevivência do organismo.

\subsection{Ciclo de vida - Reprodução assexual}

Uma vez em meio de cultura, em condições apropriadas e em abundância de nutrientes, o tecido vegetativo ou micélio continua crescendo indefinidamente. Porém, após o tempo necessário para aquisição de competência, e se houver indução por aeração, os compartimentos mais velhos da hifa tem condições de diferenciar e podem vir a formar o conidióforo, o qual é a estrutura que vai sustentar a produção dos conídios ou esporos assexuais. Os eventos que tomam parte durante a formação do conidióforo foram estudados por Clutterbuck (1977). Neste item será feita uma breve descrição destes eventos, os quais podem ser revistos em detalhes em: Timberlake (1980); Timberlake (1990); Miller (1990); Yager (1990); Champe \& Simon (1992); Miller (1993); Adams et al. (1998).

O primeiro sinal da diferenciação do conidióforo é a formação da célulapé, que é um compartimento da hifa que emite uma ramificação chamada haste do conidióforo ou hifa aérea. Esta estrutura, apesar de muito parecida com uma hifa vegetativa, diferencia-se desta por possuir crescimento delimitado de 
aproximadamente $100 \mu \mathrm{m}$. A haste contém múltiplos núcleos, porém não é compartimentalizada. Ao final deste estágio, a ponta da haste aumenta de volume, formando uma estrutura globular conhecida por vesícula. Este estágio é muito importante pois marca o final do ciclo de vida de $A$. nidulans como organismo multinucleado. Daí para frente, todos os tipos celulares serão uninucleados. Isto representa uma grande alteração nos padrões de regulação do ciclo celular do fungo.

Neste ponto, os núcleos presentes na vesícula vão se posicionar na periferia da mesma, justamente onde vão surgir os brotamentos que darão origem às métulas. Estas aparecem como uma expansão da parede da vesícula. Este novo tipo celular vai crescer aumentando de volume e adquirindo formato ovalado. O brotamento da métula lembra muito a formação do broto que ocorre durante a reprodução assexual da levedura S. cerevisiae.

A visualização dos microtúbulos citoplasmáticos utilizando imunofluorescência, possibilita a observação da migração do núcleo para dentro da métula. Os eventos que se seguem devem ser muito precisos, para que o programa de desenvolvimento tenha sucesso. Um único núcleo adentra a métula e este núcleo é programado para se dividir apenas duas vezes. A primeira divisão se dá quando a métula, já totalmente formada, brota pela primeira vez, formando os primórdios da fiálide. Um núcleo-filho migra para dentro da fiálide e o núcleo que permaneceu dentro da métula entra em mitose novamente, e então um segundo brotamento do ápice da métula, ao lado da primeira fiálide é formado, e mais uma vez o núcleo-filho entra na fiálide.

A próxima estrutura a ser formada é o conídio. Este aparece como um brotamento no ápice da fiálide. O núcleo migra para a extremidade superior e ai sofre mitose. O núcleo distal em relação ao conídio permanece na fiálide, e o outro entra em direção ao conídio imaturo. $O$ poro que permite a comunicação entre a fiálide e o conídio fecha-se, isolando as duas estruturas. Um novo brotamento surge da fiálide e então o núcleo da mesma entra novamente em 
mitose, e assim por diante, de modo que cada fiálide produz uma cadeia de conídios, sendo o apical o mais velho e o basal o mais jovem.

Neste ponto, mais uma vez há completa reprogramação do ciclo mitótico. Até no estágio de haste o padrão celular era multinucleado, onde várias divisões mitóticas eram permitidas sem a necessidade de ocorrer citocinese; no próximo estágio o padrão celular passa a uninucleado sendo que - ciclo celular foi reprogramado para que o núcleo da métula passasse por apenas duas divisões e entrasse em dormência. E na fiálide vai haver outra reprogramação, onde os núcleos vão passar a sofrer o que é conhecido por "mitose direta". Neste caso, o núcleo da fiálide passa a se dividir sucessivas vezes para doar núcleos para os conídios em formação. É interessante notar aqui, que o comprometimento entre divisão nuclear e citocinese se torna bastante pronunciado, sendo necessário haver divisão celular em seguida da mitose.

Como estrutura de resistência o conídio passa por um periodo de maturação, onde há deposição de várias camadas na parece celular que o tornam impermeável. Após esta fase, seu núcleo permanece estacionado na fase $\mathrm{G} 1$ do ciclo celular.

No momento que os esporos assexuais se encontram em condições adequadas de nutrientes, temperatura, aeração e umidade, a dormência é quebrada e o núcleo volta a dividir-se novamente. Este ponto é crítico no ciclo de vida do fungo, pois novamente há o estabelecimento do programa celular multinucleado, o qual dá oportunidade à colônia de crescer na forma de filamentos e assim explorar seu substrato de maneira eficiente.

2.5.1. Regulação gênica do desenvolvimento do conidióforo

Nas últimas três décadas foi realizado um significativo avanço no campo da morfogênese do conidióforo (Clutterbuck, 1969; Martinelli \& Clutterbuck, 
1971; Clutterbuck, 1977; Martinelli, 1979; Timberlake, 1980; Timberlake \& Marshall, 1988; Timberlake, 1990; Miller, 1990; Miller, 1993; Timberlake \& Clutterbuck, 1994; Adams et al., 1998).

O impulso inicial no sentido da caracterização genética da diferenciação assexual foi dado por Clutterbuck (1969), quando foi feita uma extensa análise mutacional em busca de mutantes que afetassem a formação do conidióforo. Este autor classificou os mutantes obtidos em quatro grupos: 1) mutantes para modificação do conídio (wet-white e dark); 2) mutantes modificadores do conidióforo (stunted e medusa); 3) mutantes aconidiais (Bristle e abacus) e 4) mutantes que afetam a pigmentação do conidióforo (ivory $A$ e $B$ ).

Dentre estas classes de loci morfogenéticos alguns despertaram interesse especial: Bristle (brlA), abacus (abaA), wet-white (wetA), stunted (stuA), medusa (medA) e "esterígma primário anucleado" (apsA). A razão do interesse é que os três primeiros genes apresentam bloqueio em três fases diferentes do desenvolvimento do conidióforo. Mutantes para o locus brlA geralmente tem crescimento indefinido da haste e nunca chegam a diferenciar a vesícula ou qualquer outra estrutura de reprodução. Abacus desenvolve haste, vesícula, e métulas. As fiálides se desenvolvem, mas nunca produzem conídios, ao invés, produzem outras fiálides, formando longas cadeias de células. O mutante wet-white forma conídios que sofrem autólise e dão à colônia um aspecto "molhado". A razão do interesse por stuA e medA, é que estes modificam a morfologia do conidióforo. O mutante stuA1 produz conidióforos pouco elaborados e de tamanho anão; mutantes medA6 produzem fiálides que se diferenciam novamente em conidióforos completos, chamados conidióforos secundários. Ambos, stuA e medA, tem envolvimento com o ciclo sexual, sendo incapazes de formarem várias estruturas requeridas para o desenvolvimento do aparato sexual. Já o mutante apsA é incapaz de se desenvolver além do estágio de vesícula. Aparentemente os núcleos são 
incapazes de migrarem para dentro da métula e dar continuidade à diferenciação do conidióforo (Clutterbuck, 1969).

Posteriormente estes genes foram caracterizados do ponto de vista molecular. A partir disto foi possivel traçar as inter-relações entre eles, estabelecendo duas vias de atuação diferentes, porém contribuindo para o mesmo processo, isto é, a elaboração do conidióforo (Mirabito et al., 1989; Miller, 1990).

a) Estudo dos mutantes aconidiais

A clonagem e o mapeamento físico do gene de desenvolvimento brlA demonstrou que o mesmo codifica um fator de transcrição do tipo "Zinc-finger" (Evans \& Hollenberg, 1988). brlA ativa de uma série de outros genes envolvidos no desenvolvimento do conidióforo, entre os quais estão abaA $e$ rodA (Johnstone et al., 1985; Boylan et al., 1987; Evans \& Hollenberg, 1988; Adams et al., 1990; Chang \& Timberlake, 1993). O estudo do padrão transcricional deste gene mostrou que ele não é transcrito na hifa vegetativa, porém dois mRNA's, (brla e brl $\beta$ ) diferencialmente regulados são observadas quando o desenvolvimento é induzido. brla é regulado de acordo com o desenvolvimento e br/ $\beta$ é constitutivamente transcrito, porém a tradução temporal correta do polipeptídeo $\beta$ é dependente de uma $\mu$ ORF presente na região 5' do gene (Han et al., 1993; Prade \& Timberlake, 1993). Quanto a função biológica de brlA, acredita-se que seja responsável pela alteração no padrão de crescimento vegetativo para reprodutivo, executando esta função por meio da ativação da transcrição de vários genes requeridos para a formação do conidióforo. Quando a expressão de brlA é induzida em culturas vegetativas, sob o controle do promotor da álcool desidrogenase (alcA) há imediata formação de conídios na ponta das hifas que assumem caracteristicas que se assemelham a conidióforos bastante rudimentares. Atualmente, brlA é 
considerado o elemento chave para a morfogênese do conidióforo (Adams et al., 1990; Mirabito et al., 1989; Han et al., 1993; Prade \& Timberlake, 1993).

A clonagem e o mapeamento físico do gene abaA demonstraram que este codifica um fator de transcrição. ABAA é uma proteina de ligação ao DNA que reconhece a sequência "CATTCY". Além disso, ABAA possui uma sequência que lembra um "Zíper de Leucina", o que é indicativo de um domínio da dimerização nesta região, processo que é freqüentemente requerido nos fatores de transcrição (Boylan et al., 1987). A análise de géis de retardo de mobilidade utilizando sequências de promotores dos genes br/A, wetA, yA, rodA e mesmo o próprio abaA mostrou que estes são alvos de ligação da proteina ABAA. A expressão ectópica de abaA diminui o crescimento vegetativo, porém não leva à diferenciação do conídio. (Adams \& Timberlake, 1990a e b; Andrianopoulos \& Timberlake, 1994).

O gene wetA foi clonado por Boylan et al. (1987). O seqüenciamento do mesmo, revelou que este codifica um fator de transcrição. A proteina produzida pelo gene wetA estaria envolvida na regulação de genes necessários para a maturação dos esporos assexuais. A expressão ectópica de wetA na hifa leva ao acúmulo de mRNAs que são específicos do conídio. Mutantes wetA e linhagens que tem este gene deletado, provocam a má formação de várias camadas da parede celular do conídio, bem como os pigmentos que dão coloração ao esporo assexual (Boylan et al., 1987).

A compilação destes dados sugere que estes três genes são regulados em cascata, isto é, a interação seqüencial de brlA, abaA e wetA, controla a diferenciação temporal e espacial do conidióforo em A. nidulans (Mirabito et al., 1989). Este modelo de interação pode ser resumido no esquema abaixo:

$$
\operatorname{brl} A \leftrightarrow a b a A \rightarrow \text { wet } A
$$

O mutante apsA1 também é considerado um mutante aconidial, uma vez que o mesmo bloqueia a entrada dos núcleos para dentro da métula e impede desta forma que o desenvolvimento prossiga normalmente (Clutterbuck, 1969). 
A análise do comportamento dos núcleos na hifa vegetativa, demonstrou que os efeitos da mutação podem ser vistos também nesta fase. Clutterbuck (1994) acompanhou o crescimento de uma linhagem apsA1 desde a germinação e observou que os núcleos não se distribuem igualmente ao longo da hifa, permanecendo em grupos e deixando longos espaços vazios na hifa. A clonagem e a caracterização da sequência de aminoácidos codificada pelo gene apsA foi feita por Fisher \& Timberlake (1995). Este trabalho mostrou que apsA codifica uma proteina do tipo "coiled-coil", isto é, possui domínios espiralizados. A comparação da sequência desta proteina com outras proteinas depositadas no banco de dados mostrou a existência de homologia com o polipeptídeo NUM1 de S. cerevisiae. Esta proteina está envolvida com o posicionamento nuclear durante o brotamento nesta levedura. Não foi provado ainda uma possivel interação de APSA, ou mesmo NUM1 com os microtúbulos, - que seria de se esperar já que estes genes, nitidamente, desempenham funções na movimentação nuclear. Por este motivo Clutterbuck (1994) e Fisher \& Timberlake (1995) sugerem que a função do gene apsA seria a de posicionar os núcleos nos locais corretos para que pudessem então serem movimentados pelos microtúbulos.

b) Estudo dos mutantes modificadores do conidióforo

As análises dos genes stuA e medA também veio a esclarecer vários detalhes sobre o padrão de formação celular do conidióforo (Miller, 1990; Miller et al., 1991; Miller et al., 1992; Busby et al., 1996; Wu \& Miller, 1997; Dutton et al., 1997). A combinação das informações sobre a funcionalidade dos genes aconidiais e os modificadores do conidióforo possibilitaram traçar um modelo pelo qual estes genes interagem culminando na estrutura complexa que é o conidióforo (Busby et al., 1996). 
Martinelli (1979) construiu uma série de mutantes duplos envolvendo alelos brlA e medA. Os fenótipos apresentados pelas linhagens mutantes indicaram uma interação bastante complexa entre estes dois genes. Esta autora conclui que a expressão de brlA tem início anteriormente à expressão de Medusa, porém a atividade destes dois genes se sobrepõe temporalmente ao longo do desenvolvimento. Busby et al., (1996) estabeleceram que a expressão temporal correta de brlA e de abaA requer a presença de medA, e que a introdução de uma cópia extra do gene brlA é capaz de suprimir o fenótipo mutante medA26 e restabelecer os niveis corretos do transcrito abaA.

O mutante stuA1 possui conidióforos bastante reduzidos em tamanhoos quais apresentam baixo nivel de complexidade, diferenciando poucos conídios na superfície da vesícula. $O$ gene stuA possui uma estrutura complexa como a apresentada pelo gene brlA. Possui duas unidades transcricionais, stu $\alpha$ e stu $\beta$, sob o controle de $3 \mu$ ORFs. O gene stuA não é expresso na hifa vegetativa, mas logo após a aquisição de competência a transcrição aumenta em cerca de 50 vezes permanecendo alto durante todo o processo de desenvolvimento e volta a cair à níveis não detectáveis no conídio maduro (Miller et al., 1991; Miller et al., 1992).

A proteina codificada pelo gene stuA pertencente à família de fatores de transcrição bHLH ("basic-Helix-Loop-Helix"), os quais são bastante conhecidos em Eucariotos. O domínio de ligação ao DNA de stuA foi designado como sendo do tipo "APSES". As proteínas que possuem este tipo de domínio de ligação ao DNA regulam importantes processos biológicos, como morfogênese e ciclo celular em S. cerevisiae, Sok2p e Phd1p (Gimeno \& Fink, 1994), em Candida albicans, Efg1p (Stold et al., 1997), e Asm1p em Neurospora crassa (Aramayo et al., 1996).

Em $A$. nidulans foram detectados diversos elementos responsivos à stuAp ( ${ }^{A / T} C_{C G G}{ }^{T / A} N^{A V C}$ ). Estes elementos situam-se na região promotora dos genes abaA, brlA, nim $\mathrm{O}^{\mathrm{Dbf} 4 \mathrm{p}}, \operatorname{nim} \mathrm{E}^{\mathrm{cyclinB}}$, os quais desempenham funções 
durante a morfogênese do conidióforo e na progressão do ciclo celular (Dutton et al., 1997).

Dutton et al. (1997), caracterizaram stuAp como um repressor da transcrição. Observaram que os transcritos brlA, abaA awh1 tornam-se temporal e espacialmente desregulados na ausência de stuA. Os autores propõem um modelo de regulação gênica do desenvolvimento assexual, em que o modificador da complexidade do conidióforo, stuA, atua por meio da modulação da transcrição de genes que dirigem a diferenciação terminal do conidióforo, como brlA e abaA. As evidências apontam para stuA como responsável pela "sintonia fina" da expressão dos genes responsáveis pela diferenciação terminal. Isso explica porque a indução de brlA em altos niveis na hifa vegetativa, causa a formação de conidióforos rudimentares com baixo nivel de complexidade, exatamente como aqueles formados pelas linhagens que possuem o gene stuA deletado. Isto reafirma a hipótese de que stuA e brIA precisam ser paralelamente expressos para que o conidióforo possa adquirir a complexidade e a funcionalidade necessárias para a produção de conídios.

Além disso, os genes Phd1 e Efg1, os quais são homólogos à stuA, estão envolvidos na formação de pseudo-hifa em levedura de brotamento $S$. cerevisiae e em C. albicans, respectivamente (Gimeno \& Fink, 1994; Stold et al., 1997; Magee, 1997). Além da homologia de sequência existente entre estas proteinas é possivel traçar uma homologia funcional, uma vez que stuAp é indispensável para diferenciação dos esterígmas (métulas e fiálides) as quais são estruturas consideradas morfologicamente análogas à pseudo-hifa (Miller et al., 1992).

\subsubsection{Mutantes "Fluffy"}

Dorn (1970), nomeou esta classe de mutantes espontâneos em $A$. nidulans, os quais possuem diferenciação anormal e caráter invasivo. 
Caracterizam-se pela formação de grandes quantidades de hifas aéreas que nunca chegam a diferenciar conidióforos e a incapacidade de respeitar os limites de crescimento de uma colônia vizinha que tem desenvolvimento normal, crescendo sobre a mesma.

Tamame et al. (1983), isolaram outro mutante para desenvolvimento do tipo "fluffy", o qual foi induzido por meio de tratamento com o análogo da citosina, 5-azacetidina. Este agente mutagênico é incorporado no lugar da citosina e inibe a ação da enzima metiltransferase, causando assim hipometilação, e ativação imprecisa de genes silenciados por meio da metilação de bases. Vários mutantes "fluffy" foram isolados por esta metodologia, e o mapeamento genético dos mesmos mostrou que eles são todos alelos de um único gene localizado no cromossomo VIII. O mutante "fluffy" isolado por este grupo de pesquisadores não tem a caracteristica invasiva como a descrita por Dorn (1970), porém parece claro que tal mutante não consegue responder a sinalização que desencadeia a diferenciação do conidióforo. Apesar do tratamento utilizado para obtenção deste mutante, envolvendo processo de metilação, os experimentos feitos não foram capazes de detectar nenhum padrão diferencial de metilação entre o mutante, o selvagem, e linhagens tratadas com 5-azacetidina. Os dados provam que 0 fenômeno da metilação é desprezivel, tanto em A. nidulans como em A. niger, e portanto a ocorrência em alta frequência deste mutante "fluffy" deve ser 0 resultado de um outro tipo de evento mutacional que não a hipometilação.

Yager et al., (1982), descreveram um dos mais interessantes mutantes "fluffy", acoD684. Este mutante chamou a atenção dos geneticistas de $A$. nidulans por dois motivos: 1) Bloqueia $\circ$ desenvolvimento em uma fase bastante precoce, logo após a aquisição da competência, abrindo a possibilidade de que $a c o D$ possa estar envolvido na ativação direta ou indireta de brlA e 2) A mutação neste gene, leva a perda do controle genético do desenvolvimento assexual, e neste caso as linhagens portadoras desta 
mutação não mais cumprem o programa de desenvolvimento, mas passam a responder às limitações nutricionais do ambiente para que realizem a conidiogênese.

Adams et al., (1992) analisaram o acúmulo do transcrito brlA na ausência do gene acoD, (posteriormente renomeado, passou a ser fluG) e concluíram que $a c o D$ é necessário para a ativação de brlA, porém na ausência do mesmo, brlA pode ser ativado por uma via paralela que não requer $a c o D$, portanto, responde a outros sinais os quais envolvem inanição da colônia. Apesar de acoD ter uma função evidente no desenvolvimento, as análises de "Northern blot" mostraram que a transcrição do gene não ocorre conforme o desenvolvimento, mas sim de maneira constante. Os autores sugerem uma possivel regulação traducional.

Lee \& Adams (1994a) observaram que quando uma colônia $a c o D^{-}$e uma $\mathrm{acoD}^{+}$crescem lado a lado, a extremidade da colônia mutante torna-se capaz de realizar a conidiogênese. Esta capacidade de complementação é dada mesmo quando as colônias são separadas por uma membrana de diálise, sugerindo que $\mathrm{o}$ gene acoD codifica um produto extracelular difusivel. A localização desta proteína por meio de anticorpos monoclonais mostrou que ela é detectada no citoplasma. O seqüenciamento demonstrou que o terminal carboxila da proteina tem homologia com uma glutamina sintetase I procariótica. Porém a linhagem mutante não apresenta auxotrofia para glutamina. A expressão ectópica de fluG na hifa vegetativa, em condições de cultura líquida, é capaz de superar o bloqueio imposto ao desenvolvimento pela condição de cultura submersa.

Como o trabalho inicial com os mutantes "fluffy" mostrou-se tão interessante, Wieser et al. (1994), fizeram uma análise em busca de mutantes com fenótipo "fluffy" que afetassem o padrão de expressão do gene brlA. Uma vez que o mesmo rege o desencadeamento do desenvolvimento assexual, o isolamento de reguladores precoces deste gene levaria ao melhor 
entendimento da via que sinaliza a esporulação. Desta análise mutacional, surgiram várias classes de mutantes, como por exemplo: flbA, B, C, D, E ("fluffy Low BrlA expression").

Lee \& Adams (1994b), iniciaram a caracterização genética e molecular dos mutantes "fluffy" que afetam a expressão de brlA analisando o gene flbA. A mutação neste gene, além de impedir o desenvolvimento assexual formando apenas um emaranhado de hifas aéreas, leva à autólise do tecido vegetativo quando a colônia atinge a maturidade, sendo por isso denominado "fluffy autolítico". O mapeamento físico e a análise da sequência prevista de aminoácidos, demonstrou que flbA codifica uma proteina do tipo RGS ("regulator of $G$ protein signaling"), isto é, tem funções na regulação da proteina heterotrimérica $G$, a qual está envolvida na sinalização intracelular (De Vries et al., 1995). flbA é homólogo ao gene Sst2 de S. cerevisiae, o qual regula negativamente a resposta celular sexual, desencadeada por ferormônio. Portanto, mutantes Sst2 são super sensiveis à ferormônio e não conseguem reverter a resposta ao mesmo (Dietzel \& Kurjan, 1987; Hasson et al., 1994; Dohlman et al., 1995). Estas observações levaram a hipótese de que a proteina FLBA desempenha um papel no controle da sinalização intracelular que determina a proliferação vegetativa versus desenvolvimento assexual em $A$. nidulans. Além disso, ficou demonstrado que a ausência de flbA reprime completamente a expressão de brlA, e a super expressão na hifa, leva também a ativação precoce de brlA e a diferenciação terminal. Isto sugere que ambos os genes fazem parte da mesma via de sinalização do desenvolvimento (Lee \& Adams, 1994b).

Esta hipótese começou a se concretizar a partir da caracterização de outro mutante "fluffy" autolitico, fadA ("fluffy Autolytic Dominant"). Yu et al (1996) demonstraram que este gene codifica a subunidade $\alpha$ da proteina heterotrimérica $G$ e que a mutação dominante neste gene, $\left(f a d A^{G 42 R}\right)$, se dá por ganho de função. Este residuo de glicina é requerido para a atividade da 
GTPase, portanto a proteina $G_{\alpha}$ fica constantemente sendo ativada pela sua ligação ao GTP, e continuamente sinaliza a proliferação vegetativa. A construção de um outro mutante dominante, o qual inativa a sinalização que causa o crescimento vegetativo ( $f a d A^{G 203 R}$ ) causa a esporulação precoce. Além disso, uma linhagem $\mathrm{flbA} / \mathrm{fad} \mathrm{A}^{\mathrm{G} 203 \mathrm{R}}$ suprime a deficiência do gene flbA.

Estes resultados estabeleceram as relaçōes existentes entre estes dois genes e as duas vias diferentes de sinalização que eles participam. Segundo o modelo proposto por Adams et al. (1998), existe uma via regulatória, na qual a proteina $\mathrm{G}_{\alpha}$ (fadA) quando associada a GTP manteria o sinal que comanda a proliferação vegetativa. $O$ fator codificado por fluG ou acoD seria responsável pela ativação de flbA, a proteína regulatória RGS que seria responsável pela inativação da proteina $\mathrm{G} \alpha$. O silenciamento da via que controla o crescimento vegetativo daria oportunidade para que a via que controla o desenvolvimento assexual entrasse em ação, ativando assim o gene brlA e por conseguinte, os demais componentes da diferenciação do conidióforo.

Outros mutantes do tipo "fluffy" foram isolados e estudados. Wieser \& Adams (1995), caracterizaram flbD, o qual produz grandes massas de hifa aérea e tem conidiogênese restrita ao centro da colônia e retardada em cerca de 24 horas, assim como flbB, C, E. A clonagem e caracterização da sequência de flbD mostrou que este gene tem homologia com a família fatores de transcrição $M y b$, bastante conhecida em mamiferos, da qual faz parte o protooncegene c-Myb (Majello et al., 1986; Lüscher \& Eisenman, 1990). A expressão ectópica deste gene em cultura submersa durante o estágio de hifa leva a ativação imprópria de brlA e causa a formação de conidióforos complexos com todos os tipos celulares existentes no selvagem e conídios viáveis.

A caracterização dos mutantes, fluG flbA, flbB, flbC, flbD, flbE demonstrou serem todos estes essenciais para a iniciação do desenvolvimento. Ainda em busca de reguladores precoces de brlA, Marhoul \& Adams (1996) utilizaram uma outra estratégia para atingir tal objetivo, neste caso, seqüências 
de DNA sob o controle de um promotor induzivel foram expressas ectopicamente em $A$. nidulans e aquelas que conseguiam ativar a transcrição de brlA sob esta condição foram estudadas. Este fenótipo foi designado fabA-P ("Forced expression Activation of Bristle"). Além da ativação de brlA algumas destas sequências eram capazes de inibir o crescimento e estimular a formação de conídios na ponta da hifa.

O primeiro destes genes a ser estudado do ponto de vista molecular foi fabM (Marhoul \& Adams 1996). O seqüenciamento deste gene demonstrou que ele codifica uma proteina de ligação ao RNA, mais especificamente à cauda poli Adenilada. A deleção deste gene demonstrou que o mesmo é essencial, e é transcrito em níveis constantes ao longo do ciclo de vida do fungo. $O$ papel que a proteina codificada por fabM desempenha no desenvolvimento por meio do acúmulo de brlA não ficou claro ainda. Porém os autores acreditam que a super expressão de FabM, poderia estabilizar os mRNAs de brlA e favorecer a tradução do mesmo. Ou então, poderia interferir com a tradução da $\mu$ ORF que regula a expressão do transcrito $\operatorname{brl} A \beta$, assim causar 0 acúmulo precoce de brlA. Atualmente estão sendo feitos esforços no sentido de testar se FABM realmente é uma proteína de ligação ao mRNA como já foi determinado para os seus homólogos.

Um aspecto interessante do estudo dos mutantes "fluffy", foi a descoberta de que os reguladores precoces do desenvolvimento também afetam o controle do metabolismo secundário em $A$. nidulans. Várias observações sugerem que os metabólitos secundários freqüentemente são produzidos durante a fase de crescimento estacionário e também durante a conidiogênese. Hicks et al. (1997) observaram que a sintese do metabólito secundário esterigmatocistina, requer a inativação da via que controla a proliferação vegetativa por meio da inibição da proteina codificada por fadA. Estes autores observaram que a expressão ectópica de flbA também aciona a sintese deste precursor da aflatoxina, e a ligação constitutiva da proteina $G \alpha$ 
ao GTP bloqueia a esporulação assexual, bem como a biossintese de esterigmatocistina.

Todos os trabalhos descritos neste item desta revisão contribuíram, significativamente, para traçar um esboço de como o desenvolvimento assexual se processa em $A$. nidulans. Porém muitas lacunas ainda estão por ser preenchidas no que se refere aos componentes desta via de transdução de sinal que capta, amplifica e transfere impulsos bioquimicos que culminam na formação do conidióforo (Adams et al., 1998).

Ficam por serem estabelecidas também as inter-relações existentes entre o controle do ciclo celular e o desenvolvimento assexual. Este campo ainda não explorado é bastante intrigante e vai revelar particularidades da sintonia fina do ciclo celular. É nítido que existem diferenças no comportamento do ciclo celular de acordo com o tipo celular, como pode ser visto no tecido vegetativo e no reprodutivo. Não se sabe porém, se o controle da mitose é feito com a participação dos mesmos elementos da hifa, somente regulados diferencialmente, ou se existem, ainda, genes que codificam proteínas regulatórias específicas do ciclo celular durante o desenvolvimento (Mirabito \& Osmani, 1994). Esta última hipótese baseia-se na existência de genes que codificam tubulinas com funções específicas para certas fases do ciclo de vida do fungo, como é o caso de tubB e tubC os quais são especificamente requeridos durante a ascosporogênese e a conidiogênese, respectivamente (Kirk \& Morris, 1991; May \& Morris, 1988).

Um exemplo interessante sobre a interação entre ciclo celular e morfogênese em diferentes tipos celulares é o mutante bncA1. O mesmo foi inicialmente isolado como um mutante produtor de conídios binucleados e trinucleados em porcentagens fixas (Pizzirani-Kleiner \& Azevedo, 1986). A análise da morfologia do conidióforo demonstrou que a mutação não só afeta o número de núcleos, como também a morfogênese das métulas e das fiálides (Pascon, 1994). Estas são freqüentemente multinucleadas e assumem uma 
morfologia tubular que lembra mais um fragmento de hifa possuindo septos que dividem a fiálide em compartimentos, do que o tipo de pseudo-hifa encontrado nas métulas e fiálides das linhagens selvagens (Pascon, 1994). A observação mais detalhada da morfologia dos núcleos e a cinética de divisão nuclear neste mutante deverá proporcionar mais informações sobre a função biológica deste gene no ciclo de vida de $A$. nidulans.

\subsection{Ciclo de vida - Reprodução Sexual}

A maioria das espécies do gênero Aspergillus são imperfeitas, isto é, não apresentam ciclo sexual. Porém algumas espécies, como é o caso de $A$. nidulans, apresentam também o ciclo sexual (Clutterbuck, 1974).

Este fungo é considerado homotálico, o que significa que uma colônia formada a partir de um único conídio ou ascósporo pode realizar o ciclo sexual, em condições de isolamento, sem a presença de um parceiro sexual, isto é, pode sofrer autofecundação (Clutterbuck, 1974). Porém a alternativa de cruzamento entre linhagens diferentes é valiosa para fins de mapeamento, sendo possivel compor mapas detalhados cruzando-se linhagens com marcadores contrastantes. Justamente a existência do ciclo sexual, e posteriormente, a descoberta do ciclo parassexual, tornaram $A$. nidulans um organismo atraente para análise genética (Roper, 1952; Pontecorvo, et al., 1954).

A sucessão de eventos que completam os dois ciclos de vida em $A$. nidulans pode ser estudada quando se inocula uma grande quantidade de esporos em meio de cultura rico à $37^{\circ} \mathrm{C}$. Rapidamente as hifas colonizam o meio de cultura e após 25 horas o micélio já está apto ao desenvolvimento. Com 40 horas o processo assexual da conidiogênese já começa a estacionar. É neste ponto que os primeiros indícios do desenvolvimento sexual aparecem. Com 90 horas observa-se ascósporos maduros (Champe \& Simon, 1992). 
O cleistotécio é a estrutura que contém os produtos da meiose, ou seja, os ascósporos. Dificilmente este pode ser visualizado nos primeiros estágios de desenvolvimento. O primeiro sinal de que o ciclo sexual está ocorrendo é o aparecimento de células Hülle. Estas são células globulares conectadas ao micélio vegetativo por meio de hifas. Tem por característica, grande quantidade da enzima lacase II ( $\rho$-difenol oxidase) a qual está envolvida com a pigmentação do conídio e do cleistotécio. Não se conhece ao certo a função das células Hülle, mas acredita-se que elas forneçam lacase II para o primórdio do cleistotécio e também sirvam para proteger o mesmo na sua fase inicial de formação (Champe et al., 1994).

A observação do cleistotécio sob microscópio óptico foi feita por Benjamin (1955). Posteriormente, Champe \& Simon (1992) descreveram que esta estrutura é formada por três camadas de hifas ramificadas. A microscopia de transmissão revelou que o cleistotécio é recoberto por uma matriz, denominada cleistina, a qual se infiltra por entre as hifas que o recobrem. É provavel que a cleistina seja sintetizada pelas próprias hifas, porém não se conhece sua natureza, nem seus componentes.

O cleistotécio possue uma coloração avermelhada, bastante característica, a qual é atribuída à ação da lacase II. O pigmento que causa esta coloração foi identificado como sendo uma poli-hidroxiantroquinona, posteriormente denominado, aspertecin (Champe \& Simon, 1992)

O papel do cleistotécio é conter os ascósporos. Por este motivo é considerado uma estrutura de resistência, uma vez que tem que garantir a viabilidade dos esporos sexuais. A morfogênese dos ascósporos não foi ainda bem estudada em $A$. nidulans, mas acredita-se que tipos celulares funcionalmente homólogos ao anterídeo e ao ascogônio venham a se formar e fundir-se formando a hifa dicariótica, a qual prolifera e os núcleos passam a se dividir sincronicamente. Eventualmente, dois núcleos se fundem formando um diplóide o qual sofre meiose originando quatro células haplóides que ocupam o 
mesmo citoplasma. Em seguida estes núcleos sofrem uma divisão mitótica e os oito núcleos são encapsulados separadamente sendo envolvidos por uma membrana dupla, chamada cápsula perisporal. Após a separação dos oito produtos individualmente, cada núcleo sofre uma segunda divisão mitótica, assim ao contrário do conídio o produto do ciclo sexual e binucleado (Champe et al., 1994).

As linhagens de laboratório originárias de Glasgow, apresentam uma mutação designada velvet (veA1) (Käfer, 1965). Esta mutação permite que a colônia realize o ciclo assexual na ausência de luz, sendo acleistotecial a $42^{\circ} \mathrm{C}$. As linhagens selvagens para veA são hipercleistoteciais, isto é desenvolvem o ciclo sexual predominantemente. Isto sugere que veA seja um fator importante no balanceamento entre o ciclos assexual e sexual (Money \& Yager, 1990). Não há dúvidas que o gene veA desempenha um papel importante no ciclo de vida do fungo $A$. nidulans, porém, não se tem, na literatura, muitas informações de como este gene atua.

Sabe-se muito pouco sobre a genética da diferenciação sexual em $A$. nidulans. O motivo disto é a própria complexidade apresentada por este evento. $O$ ciclo sexual envolve a formação de diversos tipos celulares que são menos acessiveis para análise, quando comparados aos tipos celulares desenvolvidos durante o ciclo assexual. Já na levedura $S$. cerevisiae o aparato para o desenvolvimento sexual é mais simples, portanto, mais fácil de ser manipulado. Mesmo assim, é possivel observar um crescente interesse neste assunto.

O primeiro grande passo na caracterização molecular de genes essenciais no ciclo sexual de $A$. nidulans foi 0 isolamento de um gene homólogo ao fator de transcrição ste12, o qual é considerado chave no desencadeamento da resposta sexual em S. cerevisiae (M. A. Vallim, K. Miller e B. L. Miller, em preparação). A perda da funcionalidade deste gene causa esterilidade em $A$. nidulans. No presente momento está em progresso também 
a análise de um elemento responsivo a ferormônio em $A$. nidulans ( $M$. $A$. Vallim, B. L. Miller, comunicação pessoal). Este trabalho pode vir a questionar muitos conceitos sobre o homotalismo neste fungo, bem como poderá abrir novas e surpreendentes descobertas sobre fatores de transcrição que controlam a resposta sexual.

\subsection{Objetivos}

O desenvolvimento de múltiplos tipos celulares em eucariotos depende da integração de uma série de processos biológicos. Dentre estes processos, 0 de interesse para este trabalho, são aqueles de natureza genética. A organização espacial e temporal de cada célula é dependente da expressão correta de genes específicos para cada tipo celular. Freqüentemente a regulação do ciclo celular também tem que ser coordenada com o padrão morfogenético. Isso significa que durante um processo de diferenciação celular muitas vezes há necessidade de reprogramação das diversas fases do ciclo celular.

Este quadro é absolutamente claro durante o ciclo de vida de $A$. nidulans, por isso a sua escolha como modelo biológico para estudos de morfogênese. Cada evento morfogenético descrito no texto precedente é acompanhado de uma alteração no ciclo celular. Para que estes eventos ocorram é necessário a ação de vários genes. Para o entendimento deste processo é necessário saber: onde, quando e como cada gene age. Como pode ser observado no decorrer deste texto sabe-se quem são muitos destes genes, mas ainda existem muitos espaços vazios. Muitos componentes desta engrenagem ainda estão faltando.

Por este motivo a análise de mutantes continua sendo a estratégia de escolha do geneticista preocupado com a questão do desenvolvimento e da 
diferenciação. Cada mutante corresponde a um gene que pode ser componente da engrenagem, e por este motivo, precisa ser pesquisado.

Para a execução deste trabalho de pesquisa, dois mutantes foram escolhidos para investigação. Ambos causam nucleação e morfogênese anormal de pelo menos um tipo celular. O primeiro a ser analisado do ponto de vista genético e citológico, é o mutante "binucleado", (bncA1), isolado pela primeira vez por Pizzirani-Kleiner \& Azevedo, (1986). Em seguida será feita análise genética, citológica e molecular do mutante "aconidial", aco586. Inicialmente estudado por Yager et al. (1982) quando estes autores buscavam marcadores genéticos para a fase de aquisição de competência para 0 desenvolvimento.

Com esta investigação espera-se poder determinar em qual aspecto da diferenciação estes genes tomam parte. Será testada a hipótese de que o gene bncA, faz parte da via de regulação do ciclo celular, e interage direta ou indiretamente com os componentes regulatório da mitose. $E$ para $\circ$ gene aconidial, aco586, será testada a hipótese de que ele é necessário para a correta organização espaço temporal do conidióforo. 


\section{MATERIAIS E MÉTODOS}

3.1. Linhagens de Escherichia coli:

As linhagens de bactéria utilizadas neste trabalho foram crescidas à $37^{\circ} \mathrm{C}$, com agitação constante de 200 rpms, durante um período mínimo de 12 horas, o qual é suficiente para atingir a saturação. Qualquer alteração nestas condições de crescimento serão indicadas nos respectivos experimentos.

\begin{tabular}{|c|c|}
\hline Linhagens & Genótipos \\
\hline $\mathrm{DH} 5 \alpha$ & $\begin{array}{l}\text { \$80dlacZAM15; recA1; endA1; gyrA96; thi-1; hsdR17 }\left(r_{k}^{-}, m_{k}^{+}\right) \text {; } \\
\text { supE44; relA1; deoR; } \Delta(\text { lacZYA-argF) U169 }\end{array}$ \\
\hline $\mathrm{C} 600$ & supE44; hsdR; thi-1; thr-1, leuB6;lacY1, tonA21 \\
\hline
\end{tabular}

3.2. Linhagens de A. nidulans:

\begin{tabular}{ll}
\hline Linhagens & Genótipo \\
\hline USPB2 & wA3; argB2, nicB6, bncA1 \\
UI 201 & wA3 \\
UI 203 & wA3; bncA1 \\
UI 204 & WA3; pabaA1; nimT23 \\
UI 205 & wA3, nicB6; pabaA1, nimT23 \\
UI 206 & yA2, biA1, trpC801; hisA10 \\
UI 211 & Diplóide homozigoto (UI 205 $\times$ USPB2) \\
UI 212 & Diplóide heterozigoto (UI 205 x Ul 206) \\
UI 129 & yA2; argB1; aco586 \\
Saco586.17 & biA1; aaco586 \\
MO73 & pabaA1; nimT23 \\
FGSC26 & biA1 \\
FGSC89 & biA1; argB2 \\
\hline
\end{tabular}


3.3. Meios de Cultura:

3.3.1. LB (Luria-Bertani)

\section{Triptona}

Extrato de Levedura

$\mathrm{NaCl}$
$10 \mathrm{~g}$

$5 \mathrm{~g}$

$10 \mathrm{~g}$

Para meio sólido adicionou-se, $1.5 \%$ de agar. O volume foi completado para $1000 \mathrm{ml}$ com água destilada, e o meio autoclavado.

\subsubsection{Meio $2 X-Y T$}

$\mathrm{NaCl}$

$5 \mathrm{~g}$

Extrato de levedura

$10 \mathrm{~g}$

Triptona

$16 \mathrm{~g}$

Para meio sólido adicionou-se $1,5 \%$ de ágar Difco. $O$ volume foi completado para $1000 \mathrm{ml}$ com água destilada, e o meio autoclavado.

\subsubsection{Meio TB}

Triptona

$\mathrm{NaCl}$

O volume foi completado para $1000 \mathrm{ml}$ com água destilada, e o meio autoclavado.

\subsubsection{NCZYM}

$\mathrm{NZ}$ amina (hidrolisado enzimático de caseína) $10 \mathrm{~g}$ $\mathrm{NaCl}$

$5 \mathrm{~g}$

Extrato de levedura

$5 \mathrm{~g}$

Casaminoácidos

$1 \mathrm{~g}$

$\mathrm{MgSO} 4.7 \mathrm{H} 2 \mathrm{O}$

$2 \mathrm{~g}$

$\mathrm{O} \mathrm{pH}$ foi ajustado para $7,0 \mathrm{com} 5 \mathrm{~N}$ de $\mathrm{NaOH}$. O volume foi completado para $1000 \mathrm{ml}$ água destilada e o meio foi autoclavado. 


\subsubsection{Top ágar}

LB

$10 \mathrm{mM}$ de $\mathrm{MgSO} 4.7 \mathrm{H} 2 \mathrm{O}$

$0,7 \%$ de ágar.

3.3.6. Meio Completo para A. nidulans (YG-MTV)

$\begin{array}{ll}\text { Extrato de Levedura } & 5 \mathrm{~g}(0,5 \%) \\ \text { Glicose } & 20 \mathrm{~g} \mathrm{(2 \% )} \\ \mathrm{MgSO}_{4} 0,5 \mathrm{M} & 10 \mathrm{ml} \\ \text { Solução de elementos traços } 1000 \mathrm{X} & 1 \mathrm{ml} \\ \text { Solução de vitaminas } & 5 \mathrm{ml}\end{array}$

Para meio sólido adicionou-se $1,5 \%$ de ágar Difco. $O$ volume foi completado para $1000 \mathrm{ml}$ com água destilada e o meio foi autoclavado.

3.3.7. Meio Mínimo para A. nidulans (MM)

Glicose

$10 \mathrm{~g}(1 \%)$

Solução de sais $20 \mathrm{X}$ $50 \mathrm{ml}$

Solução de elementos traços $1000 \mathrm{X}$

$1 \mathrm{ml}$

Para meio sólido adicionou-se $1,5 \%$ de ágar Difco. $\mathrm{O}$ pH do meio foi ajustado para $6,5 \mathrm{com}$ solução de $\mathrm{NaOH} 10 \mathrm{~N}$. O volume foi completado para $1000 \mathrm{ml} c \mathrm{~m}$ água destilada.

3.4. Soluções e Tampões

3.4.1. Solução de $0,1 \%$ de Tween 80 10\% de Solução estoque de Tween $80 \quad 10 \mathrm{ml}$ Água destilada $\quad 990 \mathrm{ml}$ 
3.4.2. Solução de sais $20 \mathrm{X}$ :

$\mathrm{NaNO}_{3}$

$\mathrm{KCl}$

$\mathrm{MgSO}_{4} \cdot 7 \mathrm{H}_{2} \mathrm{O}$

$\mathrm{KH}_{2} \mathrm{PO}_{4}$
$120 \mathrm{~g}$

$10,4 \mathrm{~g}$

$10,4 \mathrm{~g}$

$30,4 \mathrm{~g}$

O volume foi completado para $1000 \mathrm{ml}$ com água destilada, e a solução foi autoclavada.

3.4.3. Solução de elementos traços $1000 \mathrm{X}$

$\begin{array}{ll}\mathrm{ZnSO}_{4} \cdot 7 \mathrm{H}_{2} \mathrm{O} & 2,20 \mathrm{~g} \\ \mathrm{H}_{3} \mathrm{BO}_{3} & 1,10 \mathrm{~g} \\ \mathrm{MnCl}_{2} \cdot 4 \mathrm{H}_{2} \mathrm{O} & 0,50 \mathrm{~g} \\ \mathrm{FeSO}_{4} \cdot 7 \mathrm{H}_{2} \mathrm{O} & 0,50 \mathrm{~g} \\ \mathrm{CoCl}_{2} \cdot 6 \mathrm{H}_{2} \mathrm{O} & 0,17 \mathrm{~g} \\ \mathrm{CuSO}_{4} \cdot 5 \mathrm{H}_{2} \mathrm{O} & 0,16 \mathrm{~g} \\ \mathrm{NH}_{4} \mathrm{MoO}_{4} \cdot 2 \mathrm{H}_{2} \mathrm{O} & 0,15 \mathrm{~g} \\ \mathrm{Na}_{2} \mathrm{EDTA} & 5,00 \mathrm{~g}\end{array}$

Foi adicionado um volume de $80 \mathrm{ml}$ de água destilada e a solução foi aquecida para dissolução do $\mathrm{Na}_{2}$ EDTA.

3.4.4. Solução de vitaminas (Käfer, 1977)

Tiamina

Biotina

Colina

Ácido nicotínico

Ácido $\rho$-aminobenzóico

Pantotenato

Putrescine- $\mathrm{HCl}$

Pirodoxina- $\mathrm{HCl}$

Riboflavina
$0,0125 \mathrm{~g}$

$0,0025 \mathrm{~g}$

$2,0500 \mathrm{~g}$

$0,2500 \mathrm{~g}$

$0,0850 \mathrm{~g}$

$10,000 \mathrm{~g}$

$0,3150 \mathrm{~g}$

$0,0050 \mathrm{~g}$

$0,2500 \mathrm{~g}$ 
Adicionou-se $500 \mathrm{ml}$ de água destilada. A solução foi mantida sob refrigeração a $4^{\circ} \mathrm{C}$, e adicionada ao meio de cultura no momento do seu preparo, sendo este autoclavado em seguida

3.4.5. Soluções de requisitos nutricionais (Käfer, 1977)

\begin{tabular}{|c|c|c|}
\hline Vitaminas & Solução estoque $\left(\mathrm{g} / 100 \mathrm{mI} \mathrm{H} \mathrm{H}_{2} \mathrm{O}\right.$ & Concentração/1000 ml de meio \\
\hline 100X Tiamina & $0,25 \mathrm{~g}$ & $50 \mu \mathrm{l}$ \\
\hline 50X Biotina & $0,03 \mathrm{~g}$ & $100 \mu l$ \\
\hline 10X Colina & $4,1 \mathrm{~g}$ & $0,5 \mathrm{ml}$ \\
\hline $10 \times$ Ácido nicotínico & $0,5 \mathrm{~g}$ & $0,5 \mathrm{ml}$ \\
\hline 10X Ác. p-aminobenzóico & $0,17 \mathrm{~g}$ & $0,5 \mathrm{ml}$ \\
\hline 10X Pantotenato & $20,0 \mathrm{~g}$ & $0,5 \mathrm{ml}$ \\
\hline $10 X$ Putrescine- $\mathrm{HCl}$ & $0,63 \mathrm{~g}$ & $0,5 \mathrm{ml}$ \\
\hline 100X Piridoxina- $\mathrm{HCl}$ & $0,1 \mathrm{~g}$ & $50 \mu l$ \\
\hline 1X Riboflavina & $0,05 \mathrm{~g}$ & $5,0 \mathrm{ml}$ \\
\hline 1X Tiossulfato de sódio & $2,0 \mathrm{~g}$ & $5,0 \mathrm{ml}$ \\
\hline Aminoácidos & Solução estoque $\left(\mathrm{g} / 100 \mathrm{ml} \mathrm{H} \mathrm{H}_{2} \mathrm{O}\right)$ & Concentração/ $1000 \mathrm{ml}$ de meio \\
\hline $2 X$ L-Arginina & $8,4 \mathrm{~g}$ & $2,5 \mathrm{ml}$ \\
\hline 1X L-Cisteína & $0,4 \mathrm{~g}$ & $5,0 \mathrm{ml}$ \\
\hline 100mM L-Citrulina & $1,75 \mathrm{~g}$ & $10,0 \mathrm{ml}$ \\
\hline L-Histidina & $0,31 \mathrm{~g}$ & $5,0 \mathrm{ml}$ \\
\hline $0,5 X$ Isoleucina & $0,6 \mathrm{~g}$ & $10,0 \mathrm{ml}$ \\
\hline 1X Leucina & $0,6 \mathrm{~g}$ & $5,0 \mathrm{ml}$ \\
\hline $0,5 \times$ L-lisina- $\mathrm{HCl}$ & $3,7 \mathrm{~g}$ & $10,0 \mathrm{ml}$ \\
\hline 5X L-metionina & $2,5 \mathrm{~g}$ & $1,0 \mathrm{ml}$ \\
\hline 5X D-metionina & $2,5 \mathrm{~g}$ & $1,0 \mathrm{ml}$ \\
\hline $1 \mathrm{X}$ Ornitina- $\mathrm{HCl}$ & $3,4 \mathrm{~g}$ & $5,0 \mathrm{ml}$ \\
\hline 1X Fenilalanina & $1,0 \mathrm{~g}$ & $5,0 \mathrm{ml}$ \\
\hline
\end{tabular}




\begin{tabular}{lll} 
1X L-prolina & $1,0 \mathrm{~g}$ & $5,0 \mathrm{ml}$ \\
$40 \mathrm{mM}$ triptofano* & $0,82 \mathrm{~g}$ & $100,0 \mathrm{ml}$ \\
\hline Purinas & Soluçāo estoque $\left(\mathbf{g} / 100 \mathrm{ml} \mathrm{H}_{2} \mathrm{O}\right)$ & Concentração/1000 ml de meio \\
\hline 0,5X Adenina- $\mathrm{HCl}$ & $0,86 \mathrm{~g}$ & $10,0 \mathrm{ml}$ \\
$0,25 X$ Hipoxantina & $0,5 \mathrm{~g}$ & $20,0 \mathrm{ml}$ \\
\hline Pirimidinas & Solução estoque $\left(\mathbf{g} / 100 \mathrm{ml} \mathrm{H}_{2} \mathrm{O}\right)$ & Concentração/1000 ml de meio \\
\hline $5 \mathrm{mM}$ Uridina & - & $1,22 \mathrm{~g}$ \\
$10 \mathrm{mM}$ Uracila & - & $1,12 \mathrm{~g}$ \\
\hline${ }^{\star} \mathrm{A}$ solução de triptofano deve ser esterelizada por filtração e adicionada ao meio \\
após a autoclavagem do mesmo.
\end{tabular}

\subsubsection{Tampão TE}

Tris- $\mathrm{HCl} \quad 10 \mathrm{mM}$

NaEDTA $1 \mathrm{mM}$

3.4.7. Tampão de corrida TBE $10 X$

Tris base $108 \mathrm{~g}$

Ácido Bórico

$55 \mathrm{~g}$

NaEDTA

$7,44 \mathrm{~g}$

O volume foi completado para $1000 \mathrm{ml}$ com água destilada.

\subsubsection{TAE 50X}

Tris-base

Ácido acético glacial

NaEDTA
$242 \mathrm{~g}$

$57,1 \mathrm{ml}$

$50 \mathrm{mM}$

O volume foi completado para $1000 \mathrm{ml}$ com água destilada.

3.4.9. Tampão de amostra para eletroforese de DNA Azul de Bromofenol $0,25 \%$ 
Xileno Cianol FF

Ficoll Tipo 400
$0,25 \%$

$30 \%$

3.4.10. Solução de fenol estabilizada

O fenol líquido estocado a $-20^{\circ} \mathrm{C}$ foi descongelado a temperatura ambiente e então aquecido a $68^{\circ} \mathrm{C}$. Adicionou-se hidroxiquinolina na concentração final de $0,1 \%$. Volume igual de Tris- $\mathrm{HCl} 0,1 \mathrm{M} \mathrm{pH} 8.0$ foi adicionado. Agitou-se com auxilio de um agitador magnético durante 15 minutos.

\subsubsection{Solução estoque de RNAse.}

Uma solução estoque de $10 \mathrm{mg} / \mathrm{ml}$ foi preparada adicionando-se RNAse A (livre de DNAse) Sigma, em uma solução de Tris- $\mathrm{HCl}$ pH 7,5 e $15 \mathrm{mM} \mathrm{NaCl}$. Eventual contaminação com DNAse foi eliminada por fervura por 15 minutos. Estocou-se a $-20^{\circ} \mathrm{C}$.

3.4.12. Solução de TELS $20 \mathrm{X}$

Tris- $\mathrm{HCl} \mathrm{pH} \mathrm{7,5}$

SDS

NaEDTA
$200 \mathrm{mM}$

$4 \%$

$2 \mathrm{mM}$

\subsubsection{Solução X-Gal (5-bromo-4-chloro-3-indolyl- $\beta$-D-galactoside)}

Dissolveu-se $2 \mathrm{~g}$ de $\mathrm{X}$-Gal em $100 \mathrm{ml}$ de dimethylformamide. A estocagem foi feita à $-20^{\circ} \mathrm{C}$.

\subsubsection{Solução de IPTG Sigma (Isopropil $\beta$-D-tiogalactopiranoside)}

Dissolveu-se o equivalente a $200 \mathrm{mM}$ de IPTG em água destilada esterilizada. Esta solução foi mantida a $-20^{\circ} \mathrm{C}$ e descongelada no momento do uso. 


\subsubsection{Solução de Brometo de Etídeo}

Diluíu-se $25 \mu$ de uma solução estoque de $10 \mathrm{mg} / \mathrm{ml}$ de Brometo de Etídeo, em $500 \mathrm{ml}$ de água. A solução foi mantida sob proteção da luz à temperatura ambiente.

3.4.16. Tampão de extração de DNA total de fungos filamentos NaEDTA pH 8,5 $50 \mathrm{mM}$

SDS $0,2 \%(p / v)$

3.4.17. Tampão EB para extração de RNA

PAS Sigma (ácido $\rho$-aminosalicílico)

TNS Kodac (ácido tri-iso-propilnaftalenosulfônico) $5 \times$ RNB
$2,4 \mathrm{~g} / 20 \mathrm{ml}$ de água

$0,4 \mathrm{~g} / 20 \mathrm{ml}$ água $10 \mathrm{ml}$

A solução de PAS foi adicionada à solução de TNS, sob agitação, e posteriormente $5 X$ RNB.

\subsubsection{8. $5 \times$ RNB}

Tris- $\mathrm{HCl}$

$\mathrm{NaCl}$

$1,25 \mathrm{M}$

EGTA

$0,25 \mathrm{M}$

$\mathrm{O} \mathrm{pH}$ da solução foi ajustado para $8,5 \mathrm{com} \mathrm{NaOH}$.

3.4.19. Solução I para extração de DNA plasmidial

Tris- $\mathrm{HCl} \quad \mathrm{pH} 8.0$ $50 \mathrm{mM}$

NaEDTA $10 \mathrm{mM}$

Sacarose $25 \%$ 
3.4.20. Solução II para extração de DNA plasmidial

Dissolveu-se $12 \mathrm{mg} / \mathrm{ml}$ de lisozima. em água destilada esterilizada. Esta solução foi mantida a $-20^{\circ} \mathrm{C}$ até o momento do uso.

3.4.21. Solução III para extração de DNA plasmidial Tris- $\mathrm{HCl} \mathrm{pH} \mathrm{8,0}$ $70 \mathrm{mM}$ NaEDTA $70 \mathrm{mM}$

Triton $\mathrm{X}-100$ $0,2 \%$

3.4.22. Solução de acetato de potássio $8 \mathrm{M} \mathrm{pH} \mathrm{4,4}$ $\mathrm{CH}_{3} \mathrm{CO}_{2} \mathrm{~K}$

$8 \mathrm{M}$

Ácido acético glacial suficiente para atingir pH 4,4.

3.4.23. Solução de acetato de sódio $3 \mathrm{M} \mathrm{pH} \mathrm{6,0}$ $\mathrm{C}_{2} \mathrm{H}_{3} \mathrm{O}_{2} \mathrm{Na}$ $3 \mathrm{M}$

Ácido acético glacial suficiente para atingir $\mathrm{pH} 6,0$.

3.4.24. Tampão TM para eluição de bacteriófago $\lambda$ Tris- $\mathrm{HCl} \mathrm{pH} \mathrm{7,5}$ $10 \mathrm{mM}$ $\mathrm{MgCl}_{2}$ $10 \mathrm{mM}$

3.4.25. Tampão de ativação para extração de DNA de bacteriófago $\lambda$ Tris- $\mathrm{HCl} \mathrm{pH7,5}$ $10 \mathrm{mM}$ $\mathrm{MgCl}_{2}$ $5 \mathrm{mM}$

BSA $1 \mathrm{mg} / \mathrm{ml}$

3.4.26. Tampão $\lambda$ net Tris-HCl pH 8,0 $10 \mathrm{mM}$ 
$\mathrm{NaCl}$

NaEDTA

3.4.27. Solução de Denaturação

$\mathrm{NaOH}$

$\mathrm{NaCl}$

3.4.28. Solução de Neutralização

Tris- $\mathrm{HCl} \mathrm{pH} \mathrm{7,5}$

$0,5 \mathrm{M}$

$\mathrm{NaCl}$

3.4.29. $20 \times$ SSC

$\mathrm{NaCl}$

Citrato de Sódio

$\mathrm{O} \mathrm{pH}$ foi ajustado para 7,0 .
$100 \mathrm{mM}$

$5 \mathrm{mM}$
$0,4 \mathrm{~N}$

$0,8 \mathrm{M}$

3.4.30. Tampão MOPS 10X para "Northern Blot" MOPS $20 \mathrm{mM}$

Acetato de Sódio $5 \mathrm{mM}$

EDTA $1 \mathrm{mM}$

Formaldeído $2,2 M$

Ajustou-se o $\mathrm{pH}$ para $7 \mathrm{com}$ ácido acético depois de dissolver o MOPS e Acetato de Sódio e antes de adicionar EDTA e formaldeído.

3.4.31. Tampão de amostra para RNA

Glicerol

Tampão MOPS

Azul de bromofenol
$50 \%$

$1 \mathrm{X}$

$0,1 \mathrm{mg} / \mathrm{ml}$ 
3.4.32. Solução de Denhardt 50X

Ficol

$1 \%(\mathrm{p} / \mathrm{v})$

Polivinilpirrolidona 40

$1 \%(\mathrm{p} / \mathrm{v})$

BSA nuclease-free

$1 \%(p / v)$

Estocou-se à $-20^{\circ} \mathrm{C}$.

3.4.33. Solução de hibridização para membrana de Nylon

SSC

$6 \mathrm{X}$

Solução de Denhardt

$5 X$

SDS

$1 \%(\mathrm{p} / \mathrm{v})$

DNA esperma de salmão

$200 \mu \mathrm{g} / \mathrm{ml}$

3.4.34. Solução de hibridização TNSD para membrana de nitrocelulose

Tris- $\mathrm{HCl} \mathrm{pH} \mathrm{7,6}$ $50 \mathrm{mM}$

NaEDTA

$10 \mathrm{mM}$

$\mathrm{NaCl}$

$0,1 \mathrm{M}$

SDS

$0,1 \%$

BSA

$0,2 \%$

Polivinilpirrolidona (PVP 40)

$0,2 \%$

Ficoll

$0,2 \%$

3.4.35. Meio Osmótico

$\mathrm{MgSO}_{4}$

$1,2 \mathrm{M}$

$\mathrm{NaPi}$

$10 \mathrm{mM}$

$\mathrm{O} \mathrm{pH}$ foi ajustado para 5,8 com $1 \mathrm{M}$ de $\mathrm{Na}_{2} \mathrm{HPO}_{4}$. Esta solução foi esterilizada por filtração e estocada sob refrigeração à $4^{\circ} \mathrm{C}$.

3.4.36. Solução de equilíbrio dos protoplastos

Sorbitol

$0,6 \mathrm{M}$ 
Tris- $\mathrm{HCl} p \mathrm{pH} 7,0$

$100 \mathrm{mM}$

A solução foi autoclavada e estocada em refrigerador.

3.4.37. Tampão STC

Sorbitol

$1,2 \mathrm{M}$

Tris-HCl pH 7,5

$10 \mathrm{mM}$

$\mathrm{CaCl}_{2}$

$10 \mathrm{mM}$

A solução foi autoclavada e estocada em refrigerador.

3.4.38. Solução de PEG 4000

PEG 4000

$60 \%$

Tris- $\mathrm{HCl} \mathrm{pH} \mathrm{7,5}$

$10 \mathrm{mM}$

$\mathrm{CaCl}_{2}$

$10 \mathrm{mM}$

A solução foi autoclavada e estocada à temperatura ambiente.

\subsubsection{Meio YGS}

Extrato de levedura

$0,5 \%$

Glicose

$2 \%$

Sorbitol

$1,2 \mathrm{M}$

A solução foi autoclavada e estocada à temperatura ambiente.

3.4.40. Solução de fixação

Formaldeido

$$
3,7 \%
$$

$\mathrm{K}_{2} \mathrm{PO}_{4} \mathrm{pH} 7,0$

$50 \mathrm{mM}$

Tween 80

$0,2 \%$

3.4.41. Solução estoque de DAPI (4,6-diamino-2-phenilindol)

DAPI (Hoechst 33258) $100 \mu \mathrm{g} / \mathrm{ml}$

Esta solução foi mantida fora do alcance da luz à $4^{\circ} \mathrm{C}$. 


\subsubsection{Solução estoque de Calcofluor}

Dissolveu-se o equivalente a $100 \mu \mathrm{g} / \mathrm{ml}$ de Calcofluor (Blankophor $\mathrm{BBH}$, Standard SV-2460, Miles Organic Products Division), em uma gota de $\mathrm{KOH} 1 \mathrm{~N} \mathrm{e}$ adicionou-se o volume adequado de água destilada. A solução foi mantida em frasco escuro, fora do alcance da luz, à $4^{\circ} \mathrm{C}$.

\subsubsection{Solução de montagem de lâminas}

$\mathrm{K}_{2} \mathrm{PO}_{4} \mathrm{pH} 7,0$

Glicerol

n-propil galato
$50 \mathrm{mM}$ $50 \%$ $0,1 \%$

3.4.44. Solução de Tiabendazol (2-[4-thiabendazolyl]benzimidazole), Sigma:dissolveu-se $1 \mathrm{mg}$ de Tiabendazol em $1 \mathrm{ml}$ de água.

3.4.45. Solução de Nocodazol (methil-(5-[2-thienilcarbamil]1H-bezimidazole2YL)carbamate), Sigma: dissolveu-se 0,42 mg de Nocodazol em $1 \mathrm{ml}$ de DMSO (dimetilsulfoxide).

\subsection{Extração de DNA cromossomal de fungo filamentoso}

A extração de DNA cromossomal foi realizada com uma variação do método de Raeder \& Broda (1985). O micélio de A. nidulans foi crescido durante a noite em $50 \mathrm{ml}$ de meio mínimo líquido e, então, filtrado à vácuo e transferido para um almofariz. Com a adição de nitrogênio líquido, este micélio foi pulverizado e transferido para Tubos Falcon de $15 \mathrm{ml}$. Adicionou-se $4 \mathrm{ml}$ de solução de extração de DNA total de fungos filamentosos, e agitou-se gentilmente por inversão. Acrescentou-se $3 \mathrm{ml}$ de fenol e 1,2 $\mathrm{ml}$ de clorofórmio/álcool isoamílico $(24: 1 \mathrm{v} / \mathrm{v})$. Agitou-se por inversão e incubou-se em gelo por 10 minutos. Centrifugou-se a $8000 \mathrm{rpm}$ por 50 minutos a $4^{\circ} \mathrm{C}$ em centrifuga refrigerada Sorvall RC5B Du Pont Instruments. A fase aquosa foi recuperada e nova extração com 
fenol/clorofórmio/álcool isoamílico foi realizada. Centrifugou-se a $8000 \mathrm{rpm}$ por 10 minutos. Recuperou-se a fase aquosa e, então, acrescentou-se $50 \mu \mathrm{l}$ de RNAse e incubou-se por 15 minutos a $37^{\circ} \mathrm{C}$. Fez-se 2 extrações com clorofórmio/alcool isoamílico $(24: 1 \mathrm{v} / \mathrm{v})$. O DNA cromossomal foi precipitado pela adição de 0.54 volume de isopropanol gelado à fase aquosa, a precipitação foi feita à $-20^{\circ} \mathrm{C}$. Agitou-se por inversão, lentamente. Centrifugou-se imediatamente por 15 minutos a $6000 \mathrm{rpm}$. O "pellet" foi lavado com etanol $70 \%$ e seco a vácuo (Speed Vac Concentrator, Savant Inc.) por 5 minutos. O DNA precipitado foi ressuspendido em TE.

3.6. Extração de RNA de cultura vegetativa em diferentes tempos do desenvolvimento

O micélio da linhagem desejada foi crescido em $50 \mathrm{ml}$ de meio mínimo ou completo YGMTV líquido, durante a noite. No dia seguinte o mesmo foi fitrado em papel de filtro e a amostra de tecido referente ao estágio de hifa vegetativa, foi imediatamente congelado em nitrogênio líquido. As demais amostras, referentes aos vários estágios de desenvolvimento, foram filtradas e transferidas para placas Petri contendo meio mínimo ou meio completo YGMTV sólido. As placas foram incubadas à $37^{\circ} \mathrm{C}$, sem as tampas, para fornecer a maior aeração possivel às colônias. As placas foram retiradas da incubadora, nos tempos desejados e 0 material foi congelado em Nitrogênio líquido e mantido à $-80^{\circ} \mathrm{C}$. As amostras foram transferidas para almofariz contendo Nitrogênio líquido e foram pulverizadas. $O$ material foi rapidamente transferido para tubos Corex de $30 \mathrm{ml}$ contendo $7,5 \mathrm{ml}$ de Tampão EB e 3,75 ml de fenol, agitou-se em "vortex" durante 1 minuto por 3 vezes. Adicionou-se $3,75 \mathrm{ml}$ de clorofórmio, agitou-se em "vortex". As fases foram separadas por centrifugação em cetrífuga refrigerada Sorvall RC5B, rotor SS34, durante 20 minutos à $7000 \mathrm{rpm}$. A fase aquosa foi extraída, colocada em um tubo limpo, e reservada em banho de gelo. Ao restante do fenol que ficou no tubo, 
adicionou-se 2,5 ml de tampão EB, agitou-se em "vortex", e aqueceu-se em banhomaria à $60^{\circ} \mathrm{C}$. Após este período, deixou-se o material na bancada até que 0 mesmo atingisse temperatura ambiente, agitou-se em "vortex" e foi feita a separação das fases em centrifuga refrigerada como anteriormente. Extraiu-se a fase aquosa a qual foi adicionada ao tubo reservado previamente, em banho de gelo, contendo a fase aquosa da primeira centrifugação. Fez-se duas extrações com 7,5 ml de fenol/clorofórmio, e uma extração com 7,5 ml de clorofórmio. $O$ volume da fase aquosa foi medido, e à ele foi adicionado $10 \mathrm{M}$ de $\mathrm{LiCl}$, em quantidade suficiente para obter uma concentração final de $2 \mathrm{M}$. Foi feita precipitação durante a noite à $4^{\circ} \mathrm{C}$. No dia seguinte, o material foi centrifugado por 20 minutos a $12000 \mathrm{rpm}$ em centrifuga Sorvall, rotor SS34. O sobrenadante foi descartado e o "pellet" foi ressuspendido em TELS aquecido à $60^{\circ} \mathrm{C}$. A concentração foi determinada em espectrofotômetro, com comprimento de onda igual a $260 \mathrm{~nm}$. Os RNA's foram mantidos à $-80^{\circ} \mathrm{C}$, e descongelados somente no momento do uso. $O$ enriquecimento da preparação para RNA poliAdenilado, foi realizado utilizando colunas de matriz celulósica contendo Oligo(dT) tipo 7 , Pharmacia.

3.7. Técnica de "Southern Blot" (Sambrook et al., 1989)

As amostras foram carregadas em gel de agarose (1\%). Uma corrente de $4 \mathrm{~V} / \mathrm{cm}$, foi aplicada até que o marcador de corrida, (Azul de Bromo-fenol), alcançasse a distância desejada. O gel foi corado em uma solução de Brometo de Etídeo e observado sob luz ultra-violeta (UV). A depurinação do DNA foi feita pela exposicão do gel à luz UV por 5 minutos, ou por imersão do mesmo em uma solução de $0,25 \mathrm{~N}$ de $\mathrm{HCl}$ por 20 minutos. Os processos de denaturação e netralização, foram feitos com as respectivas soluções desnaturante $e$ neutralizante, durante 30 minutos, sob fraca agitação, à temperatura ambiente. $A$ transferência foi feita para membrana de Nylon (Hybond-N, Armesham Life 
Science) em $25 \mathrm{mM}$ de $\mathrm{Na}_{2} \mathrm{PO}_{4} \mathrm{pH}$ 6,5, por um período mínimo de 12 horas. $\mathrm{O}$ DNA foi fixado à membrana, utilizando luz ultra-violeta (UV Stratalinker 1800, Stratagene). As membranas foram mantidas em sacos de plástico, fora do alcance da luz, à temperatura ambiente, até o momento do uso.

3.8. Técnica de "Northern blot" (Sambrook et al., 1989)

O gel para eletroforese de RNA foi preparado na concentração de 1,2\% de agarose e 2,2 M de formaldeído, ambos diluídos em tampão MOPS $1 \mathrm{X}$. O tampão de corrida utilizado foi MOPS $1 \mathrm{X}$. As amostras foram preparadas em 2,2, M de formaldeído, $50 \%$ de formamida, 1 X MOPS, $10 \mu \mathrm{g}$ de RNA total ou $3 \mu \mathrm{g}$ de RNA PoliAdenilado. $O$ volume de cada amostra foi completado para $20 \mu \mathrm{l}$ com TELS. Adicionou-se $2 \mu$ l de tampão da amostra de RNA no momento da corrida para monitoramento da mesma. Previamente ao carregamento no gel, as amostras foram aquecidas à $60^{\circ} \mathrm{C}$ por 15 minutos. Após a eletroforese para separação dos RNA's, os mesmos foram transferidos para membrana de Nylon (Hybond-N, Armesham Life Science), em 20X SSC, durante um período mínimo de 12 horas. A metodologia de fixação dos RNAs à membrana foi a mesma descrita para DNA no item anterior.

\subsection{Extração em pequena escala de DNA Plasmidial de E.coli}

Inoculou-se uma colônia isolada de bactéria em $2 \mathrm{ml}$ de meio de cultura LB líquido contendo o antibiótico adequado. O material foi crescido nas condições padronizadas. As células foram transferidas para tubo eppendorf $(1,5 \mathrm{ml})$ e coletadas por centrifugação em microcentrifuga (velocidade máxima, 1 minuto), descartando-se o sobrenadante. Adicionou-se $400 \mu \mathrm{l}$ da solução I (3.4.19) ressuspendeu-se em vortex e adicionou-se $50 \mu$ da solução II (3.4.20). Manteve-se em banho de gelo por 5 minutos. Adicionou-se $300 \mu$ da solução III 
(3.4.21). Após este passo, a lise das células completou-se. Manteve-se em banho de gelo por mais 5 minutos, e então transferiu-se para banho à $70^{\circ} \mathrm{C}$ por 10 minutos. Coletou-se o sobrenadante após centrifugação por 10 minutos. Ao lisado adicionou-se $2 \mu$ de DEPc (Dietilpirocarbonato) e transferiu-se para banho a $70^{\circ} \mathrm{C}$ por 10 minutos. Resfriou-se em banho de gelo e procedeu-se a centrifugação por 5 minutos. O sobrenadante foi coletado e fez-se a precipitação do DNA plasmidial, com etanol $100 \%$, em volume suficiente para completar 0 tubo eppendorf. Centrifugou-se novamente por 10 minutos e descartou-se o sobrenadante. O DNA que ficou no fundo do tubo foi seco sob vácuo e ressuspendido em TE adiconado de $1 \mu \mathrm{l}$ de RNAseA. O volume de TE usado variou de $20 \mu$ para plasmídio de baixo número de cópias e cosmídio, a $50 \mu \mathrm{l}$ para plasmídio de alto número de cópias. Este tipo de preparação rendeu DNA plasmidial ou cosmidial em quantidade e qualidade suficiente para ser utilizado em subsequentes digestões, ligações e construções em geral, bem como para reações de seqüenciamento.

\subsection{Extração de DNA plasmidial em larga escala de E. coli}

Inoculou-se $500 \mathrm{ml}$ de meio $2 \mathrm{X}-\mathrm{YT}$ acrescido do antibiótico adequado, com um pré-inóculo de $5 \mathrm{ml}$ crescido durante a noite, proveniente de uma colônia isolada da bactéria de interesse. As células foram coletadas por centrifugação na velocidade de 5000 rpms, por 10 minutos, em centrifuga Sorvall RC5B, rotor tipo GSA. Adicionou-se $9 \mathrm{ml}$ da solução l, e ressuspendeuse muito bem o material. Acrescentou-se $1 \mathrm{ml}$ da solução Il e manteve-se em banho de gelo por 10 minutos. Preparou-se $20 \mathrm{ml}$ da solução de lise composta de $1 \%$ de SDS e $0,4 \mathrm{~N}$ de $\mathrm{NaOH}$, a qual foi vagarosamente adicionada à suspensão de células, sendo que no final foi feita vigorosa agitação. Neste passo obteve-se completo clareamento da solução. Em seguida adicionou-se $10 \mathrm{ml}$ de solução de acetato de potássio, procedeu-se novamente agitação 
vigorosa, e manteve-se em banho de gelo por no mínimo 30 minutos. Centrifugou-se esta suspensão à 8000 rpms por 15 minutos (rotor SS34 ou HB4). Coletou-se o sobrenadante cuidadosamente para evitar a camada de proteinas. Fez-se uma extração com $10 \mathrm{ml}$ de fenol/clorofórmio, recuperou-se a fase aquosa, e foi feita a precipitação dos ácidos nucleicos com 0,1 volume de acetato de sódio e 1,1 volumes de isopropanol gelado. A precipitação feita para obtenção de plasmídios de baixo número de cópias e cosmídios foi feita por no mínimo 16 horas, à $-20^{\circ} \mathrm{C}$. Para obtenção de plasmídios de alto número de cópias, a precipitação foi feita por 1 hora à $-20^{\circ} \mathrm{C}$. A recuperação do material foi feita por centrifugação à 8000 rpms por 15 minutos (rotor SS34 ou HB4). Descartou-se o sobrenadante, os tubos foram secos sob vácuo, e os ácidos nucleicos ressuspendidos em 2,5 $\mathrm{ml}$ de TE. Foi feita digestão com $1 \mu \mathrm{l}$ de RNAse por 1 hora.

3.11. Purificação de DNA plasmidial em gradiente de $\mathrm{CsCl}_{2}$ (Sambrook, et al, 1989)

O DNA dissolvido em TE obtido no item anterior, foi pesado de modo a se obter exatamente $4,02 \mathrm{~g}$, sendo necessário adicionar mais TE para atingir o peso exato. A ele foi adicionado 4,2 g de Cloreto de Césio, tendo-se o cuidado de dissolver muito bem os cristais do sal. Em seguida adicionou-se $270 \mu \mathrm{l}$ de Brometo de Etídeo (10 mg/ml). Esta solução foi então carregada dentro de um tubo de ultracentrifuga. "Quickseal" Beckman $13 \times 51 \mathrm{~mm}$ A boca do tubo foi selada e procedeu-se a ultracentrifugação de $47000 \mathrm{rpms}$, à temperatura ambiente, sob vácuo, durante um período mínimo de 6 horas. $O$ equipamento utilizado foi ultracentrifuga Beckman L8-70M, rotor tipo Vti65.2. A formação das bandas no gradiente em Cloreto de Césio puderam ser observadas sob luz ultravioleta, sendo coletada a banda correspondente ao DNA plasmidial com auxílio de seringa e agulha. A extração do Brometo de Etídio foi feita com 
álcool isoamílico. O DNA plasmidial foi então dialisado, com objetivo de eliminar a alta concentração de Cloreto de Césio. A diálise procedeu-se em $500 \mathrm{ml}$ de TNE 1X, sendo feitas 3 trocas de tampão. Cada troca sendo de no mínimo 3 horas.

3.12. Células competentes para transformação de E.coli

Uma colônia de bactéria da linhagem $\mathrm{DH} 5 \alpha$ foi inoculada em $1 \mathrm{ml}$ de meio líquido LB sem qualquer antibiótico. Após a saturação este pré-inóculo foi usado para inocular $100 \mathrm{ml}$ de meio líquido LB. Deixou-se que as células crescessem até $O D=0,6$. As mesmas foram então resfriadas em banho de gelo e transferidas para tubo de centrífuga também resfriados. A centrifugação foi feita a 5000 rpms por 5 minutos em centrifuga refrigerada. $O$ sobrenadante foi descartado e as células foram gentilmente ressuspendidas em $50 \mathrm{ml}$ de $\mathrm{CaCl}_{2} 50 \mathrm{mM}$, gelado. As células foram deixadas em banho de gelo por 2 horas. Novamente foi feita centrifugação nas condições anteriores, e as células ressuspendidas em $10 \mathrm{ml}$ da mesma solução. Para estocar as células competentes, ressuspendeu-se em $8 \mathrm{ml}$ de $\mathrm{CaCl}_{2} 50 \mathrm{mM}$ adionou-se $2 \mathrm{ml}$ de $80 \%$ de Glicerol, aliquotou-se em eppendorfs, os quais foram mantidos à $-80^{\circ} \mathrm{C}$.

\subsection{Transformação de E. coli}

As células competentes preparadas de acordo com o item anterior, foram descongeladas e mantidas o tempo todo em banho de gelo. Adicionou-se o DNA plasmidial ao tubo contendo $100 \mu$ de células competentes, agitou-se gentilmente e manteve-se em banho de gelo por 20 minutos. Em seguida, os tubos foram transferidos para banho à $37^{\circ} \mathrm{C}$ por 5 minutos. Imediatamente após este tempo adicionou-se $1 \mathrm{ml}$ de meio LB sem antibiótico e fez-se incubação de 1 hora, à $37^{\circ} \mathrm{C}, 200$ rpms. Após este periodo as células foram 
coletadas por centrifugação e plaqueadas em meio LB com antibiótico adequado.

3.14. Empacotamento de cosmídio e bacteriófago $\lambda g t 10$

Para a amplificação do banco de DNA genômico em cosmídio, para o resgate dos cosmidios do genoma de linhagens transformadas de A. nidulans, e para empacotamento de bacteriófago $\lambda$ foi usado o kit de empacotamento "Gigapack Plus", Promega. O banco de cDNA usado neste trabalho foi gentilmente cedido pelo Dr. Steve Osmani.

3.15. Transfecção de células de E. colipor cosmídios empacotados

As células usadas para transfecção, utilizando cosmídios empacotados, foram E.coli $\mathrm{DH} 5 \alpha$, crescidas em $100 \mathrm{ml}$ de meio TB suplementado com $10 \mathrm{mM}$ de $\mathrm{MgSO}_{4}$ e $0,2 \%$ de maltose. A incubação foi feita à $30^{\circ} \mathrm{C}, 200 \mathrm{rpms}$, durante a noite. No dia seguinte, as células foram coletadas em centrifuga Sorvall, a 2000 rpms (rotor HB4 ou SS34), ressuspendidas em $40 \mathrm{ml}$ de $10 \mathrm{mM}$ de $\mathrm{MgSO}_{4}$, diluídas até $\mathrm{OD}=0,5$ e mantidas em banho de gelo até o momento do uso. A transfecção foi feita utilizando-se $50 \mu \mathrm{l}$ de da reação de empacotamento e $200 \mu \mathrm{l}$ de células competentes. Este sistema foi mantido à $37^{\circ} \mathrm{C}$ por 20 minutos, quando então foi adicionado $1 \mathrm{ml}$ de meio LB e incubado sob agitação de $200 \mathrm{rpms}$, à $37^{\circ} \mathrm{C}$, durante 1 hora. Após este periodo o material foi coletado por centrifugação e plaqueado em meio LB com o antibiótico adequado. Foi feito também controle negativo, isto é, apenas as células competentes sem a reação de empacotamento. 
3.16. Preparo de células de E. coli para transfecção e lise por bacteriófago $\lambda \mathrm{gt} 10$

Cresceu-se uma cultura de células de E.coli, linhagem C600 em $100 \mathrm{ml}$ de meio NZCYM acrescido de $0,2 \%$ de maltose, à uma temperatura de $30^{\circ} \mathrm{C}$ durante um período de 16 horas, rotação de 200 rpms. As células foram coletadas por centrifugação em Sorvall RC5B, 5000 rpms, em rotor HB4/SS34, por 5 minutos. O sobrenadante foi descartado e as células ressuspendidas em $40 \mathrm{ml}$ de $\mathrm{MgSO}_{4}$. Fez-se diluição, até a obtenção de OD=0,5.

3.17. Transfecção e lise de células por bacteriófago $\lambda$ gt10

Em tubos de vidro esterilizados adicionou-se $100 \mu \mathrm{l}$ de células competentes para transfecção (3.16) e $100 \mu l$ da diluição desejada do bacteriófago $\lambda$ gt 10; manteve-se este sistema em banho à $37^{\circ} \mathrm{C}$ por 20 minutos sem agitação. Aqueceu-se o Top ágar à $42^{\circ} \mathrm{C}$ e adicionou-se $3 \mathrm{ml}$ do mesmo à mistura de células e $\lambda$ gt10; agitou-se rapidamente e verteu-se em placa de Petri, previamente aquecida à $37^{\circ} \mathrm{C}$, contendo meio LB sólido. Após a solidificação do top ágar, as placas de Petri foram incubadas à $37^{\circ} \mathrm{C}$ até a formação das placas de lise (entre 6 e 16 horas geralmente as placas se tornam visiveis).

3.18. Imobilização de placas de lise em suporte sólido

Após a formação das placas de lise descritas no ítem anterior, as placas de Petri foram deixadas na geladeira até seu resfriamento completo. Sobre cada placa foi colocada uma membrana de nitrocelulose (Protram, BA85, $0,45 \mu \mathrm{m}, 132 \mathrm{~mm}$ ), por 2 minutos para que este suporte sólido absorvesse os bacteriófagos. Foi feita a desnaturação e a neutralização (solução 
desnaturante e netralizante respectivamente) por 20 segundos; em seguida as membranas foram colocadas em 3 X SSC por 15 minutos. Após este passo, as membranas foram secas ao ar e colocadas finalmente em forno à vácuo à $70^{\circ}$ C por 2 horas. Estas membranas foram estocadas em geladeira dentro de sacos plásticos para posterior uso em experimentos de hibridização.

3.19. Hibridização de placas de lise fixadas em membrana de nitrocelulose

As membranas preparadas segundo 0 item anterior foram colocadas para pré-hibridizar durante 2 horas à temperatura de $65^{\circ} \mathrm{C} \mathrm{em} 20 \mathrm{ml}$ de tampão TNSD adicionado de $1 \mathrm{ml}$ de DNA de esperma de Salmão (DNA $\mathrm{S}^{3}$ ). A hibridização foi feita na mesma solução, pela adição de cerca de $10 \mu \mathrm{Ci}$ da sonda apropriada, à mesma temperatura. A hibridização ocorreu durante toda a noite. No dia seguinte as membranas foram lavadas 4 vezes da seguinte maneira: 2 lavagens em 2 X SSC acrescido de $0,1 \%$ de SDS, durante 20 minutos, à $65^{\circ} \mathrm{C}$ sob agitação; e mais 2 lavagens em $0,2 \mathrm{X}$ SSC acrescido de $0,1 \%$ de SDS, por 20 minutos à mesma temperatura. As membranas foram secas ao ar, e finalmente expostas contra filme de raio $X$, com tela intensificadora à $-80^{\circ} \mathrm{C}$. Este mesmo protocolo pode ser usado para transferência e hibridização de ácidos nucleicos provenientes de colônias de bactérias, fixados em membrana de nitrocelulose.

\subsection{Extração de DNA de bacteriófago $\lambda$}

Adicionou-se $10 \mathrm{ml}$ de de tampão TM à placa de Petri contendo placas de lise confluentes. Este material foi deixado durante uma noite na geladeira. No dia seguinte coletou-se o lisado com auxilio de uma pipeta; a este adicionou-se $25 \mu \mathrm{l}$ de tampão de ativação contendo $1 \mathrm{mg} / \mathrm{ml}$ de DNAse 1 . Fez- 
se uma incubação de 30 minutos à $37^{\circ} \mathrm{C}$. Em seguida fez-se uma centrifugação de 5000 rpms por 5 minutos. Foi coletado o sobrenadante, e as células que se acumularam no fundo do tubo foram descartadas. Adicionou-se $0,6 \mathrm{~g}$ de $\mathrm{NaCl}$ e 0,7 g de PEG 8000 ao sobrenadante, dissolveu-se muito bem, e deixou-se na geladeira durante à noite. No dia seguinte centrifugou-se à 8000 rpms, em rotor HB4/SS34 por 20 minutos. O sobrenadante foi descartado e $\circ$ pellet ressuspendido em $0,6 \mathrm{ml}$ do tampão $\lambda$ net em tubo eppendorf. Foi feita centrifugação em microcentrifuga usando $14000 \mathrm{~g}$, por 5 minutos. O pellet foi descartado e no sobrenadante foram feitas duas extrações com fenol/clorofórmio. Foi feita precipitação com 1,1 volumes de isopropanol à $80^{\circ} \mathrm{C}$ por 30 minutos. Fez-se nova centrifugação, e o pellet foi lavado duas vezes com $50 \%$ de isopropanol e $0,14 \mathrm{M}$ de acetato de sódio. O DNA foi seco sob vácuo e ressuspendido em $50 \mu \mathrm{l}$ de TE adicionado de $10 \mu \mathrm{g} / \mathrm{ml}$ de RNAseA.

\subsection{Marcação de sonda radioativa}

As sondas marcadas com $\left[\alpha^{32} \mathrm{P}\right]$ dCTP foram feitas por "Random Prime" utilizando o kit "RadPrime Labeling System", Gibco BRL, de acordo com o protocolo fornecido pelo fabricante. Os nucleotideos não incorporados foram separados com o uso da matriz Biogel P60, 130 $\pm 40 \mu \mathrm{m}$, BioRad. As sondas foram fervidas durante 5 minutos e rapidamente resfriadas em banho de gelo, previamente ao seu uso.

\subsection{Sintese de cDNA para sonda radioativa}

Utilizou-se o Kit "cDNA SuperScript Pre-amplification System" da GibcoBRL. Os cDNAs construidos para servirem como sonda radioativa, foram sintetizados a partir de RNA PoliAdenilado extraído da hifa vegetativa da 
linhagem FGSC26, somente até a primeira fita com o auxílio do Kit de sintese de CDNA, sendo a segunda fita sintetizada com o Kit "Radprime DNA labeling system" da Gibco-BRL, usando como nucleotídeo radioativo $\left[\alpha^{32} P\right]$ dCTP. A sonda foi fervida durante 5 minutos e rapidamente resfriada em banho de gelo, antes do seu uso.

\subsection{Obtenção de protoplastos de A. nidulans}

Inoculou-se aproximadamente $1 \times 10^{6}$ conídios de A. nidulans em $250 \mathrm{ml}$ de meio mínimo acrescido dos requisitos nutricionais da linhagem. Esta cultura foi crescida durante a noite (máximo de 16 horas) à $37^{\circ} \mathrm{C}, 200 \mathrm{rpms}$. No dia seguinte o micélio foi coletado por filtração, o excesso de umidade foi retirado com papel toalha, e o material ressuspendido em $10 \mathrm{ml}$ de meio osmótico, contendo $40 \mathrm{mg}$ de Novozim 234 dissolvida em meio osmótico, $12 \mathrm{mg}$ de BSA Sigma, também dissolvido em meio osmótico, e 0,4 ml de helicase (Sigma G2887). Este sistema lítico foi incubado à $30^{\circ} \mathrm{C}$, sob agitação de $50 \mathrm{rpm}$. A protoplastização foi feita em um prazo máximo de 2 horas, sendo que a cada 30 minutos foi feita uma lâmina para acompanhamento microscópico. Após este periodo os protoplastos foram colocados em tubos Corex de $30 \mathrm{ml}$ e sobre eles verteu-se, delicadamente, $10 \mathrm{ml}$ de solução de equilibrio dos protoplastos. Foi feita a centrifugação em gradiente utilizando rotor HB4, 5000 rpms, durante 15 minutos, em centrifuga refrigerada Sorvall RC5B. Os protoplastos foram coletados da interface com pipeta Pasteur. Foram então lavados com $10 \mathrm{ml}$ de tampão STC por duas vezes, à 7000 rpms por 5 minutos. Após a última lavagem foram ressuspendidos em STC, e contados em câmara de Neubauer. 


\subsection{Transformação de A. nidulans}

Adicionou-se $10 \mu \mathrm{g}$ de DNA à um tubo de microcentrifuga ou em tubo de $12 \mathrm{ml}$ LPE e $100 \mu \mathrm{l}$ de STC contendo $1 \times 10^{8}$ de protoplastos. Incubou-se à temperatura ambiente por 25 minutos; em seguida adicionou-se $1,2 \mathrm{ml}$ de solução de PEG 4000; agitou-se gentilmente e incubou-se por mais 20 minutos. Centrifugou-se em rotor HB4/SS34 à $7000 \mathrm{rpms}$, por 10 minutos, $4^{\circ} \mathrm{C}$, em centrifuga refrigerada Sorvall. Escorreu-se o PEG deixando os tubos invertidos até que toda a solução tivesse sido drenada. Adicionou-se $2,5 \mathrm{ml}$ de meio YGS, os protoplastos foram ressuspendidos gentilmente. $E$ foram incubados à $37^{\circ} \mathrm{C}$, sob agitação de 200 rpms, por 2 horas. Após este período, fez-se centrifugação, 7000 rpms, por 5 minutos. O sobrenadante foi descartado e os protoplastos ressuspendidos em $100 \mu \mathrm{l}$ de STC, os quais foram plaqueados em meio mínimo, devidamente suplementado com o estabilizador osmótico $(1,2 \mathrm{M}$ de sorbitol) e os requisitos nutricionais, menos a marca auxotrófica de seleção dos transformantes.

3.25. Coloração de núcleos e de parece celular com corantes fluorescentes

Para observação da germinação de conídios, tubo germinativo e compartimentos das hifas, os conídios foram incubados sobre lamínulas colocadas no fundo de placas de Petri contendo meio YGMTV. As amostras foram tiradas nos tempos determinados para cada experimento, fixadas em solução fomaldeido (item) por 30 minutos. Em seguida as lamínulas foram lavadas por 2 vezes em água destilada, e então procedeu-se a coloração utilizando-se $0,2 \mu \mathrm{g} / \mathrm{ml}$ de Calcofluor e $0,1 \mu \mathrm{g} / \mathrm{ml}$ de DAPI por 5 minutos. As lamínulas foram lavadas em água destilada, e montadas em lâminas contendo 
1 gota de tampão de montagem de lâminas. As observações foram feitas em microscópio de fluorescência Zeiss Axioplan sob luz ultra-violeta.

\subsection{Análise de heterocários}

Os heterocários foram obtidos segundo a metodologia descrita por Pontecorvo et al. (1953). Após 7 dias o material foi coletado da placa com 0,1\% de Tween 80 , lavado e filtrado por 3 vezes em seringa contendo lã de vidro esterilizada. Os conídios foram ressuspendidos em água destilada estéril e observados em microscópio óptico, para ter certeza de que o inóculo se apresentava livre de fragmentos de hifa.

\subsection{Seqüenciamento de nucleotídeos}

As reações de seqüenciamento foram feitas utilizando o kit "PRISM" Ready Reaction Dyedeoxy Terminator Cycle Sequencing" Perkin-Helmer. O seqüenciador automático utilizado foi $A B I 373 \mathrm{XL}$, do Laboratório de Biotecnologia e Bioanálise da Washington State University, Pullman, WA, E.U.A. Utilizou-se o programa PCGENE e Seq Vu 1.01 para montagem das regiões contínuas.

\subsection{Técnica fotográfica e edição das micrografias}

As micrografias apresentadas foram feitas a partir de fotografias feitas com filme branco e preto da marca Kodak Technical Pan 2415. A revelação foi feita de acordo com a recomendação do fabricante. As imagens foram digitalizadas no Departamento Fotográfico da Universidade de Idaho, Moscow, ID, E.U.A. Os painéis foram montados com auxilio dos processadores de imagens "Photoshop 3.0", e "FreeHand 5.0". 


\section{RESULTADOS E DISCUSSÃO}

\subsection{Estudo do mutante $\underline{b} \underline{i n u} \underline{u} l e a d o, b n c A 1$}

\subsubsection{Análise da germinação e cinética de divisão nuclear}

Os efeitos da mutação bncA1 foram anteriormente caracterizados no conídio e no conídióforo (Pizzirani-Kleiner \& Azevedo, 1986; Pascon, 1994). Dando continuidade a esta caracterização, o próximo passo foi observar 0 padrão de germinação nas primeiras 6 horas e determinar a cinética de divisão nuclear para a linhagem selvagem UI 201 e mutante UI 203. Este experimento foi conduzido utilizando meio completo líquido YGMTV. As amostras foram coletadas nos tempos zero, 2, 4, 5 e 6 horas. Os germinantes foram fixados e corados segundo a técnica de DAPI/Calcofluor, os quais coram núcleo, parede celular e septo. Finalmente, as lâminas foram montadas e observadas em microscópio de fluorescência sob luz ultravioleta.

Os resultados da germinação da linhagem selvagem UI 201 e mutante UI 203 estão apresentados na Figura 1A - 1D e 1E - 1I, respectivamente. A maioria dos germinantes da linhagem UI201 executaram a primeira divisão mitótica por volta de 4 horas de crescimento. As duas divisões mitóticas subseqüêntes ocorreram dentro das próximas 2 horas, como esperado (Wolkow et al.,1996). Nos experimentos de Harris et al. (1994), a primeira 
divisão do selvagem ocorre com 5 horas de incubação, isto é, 1 hora depois do observado neste trabalho. Este tipo de variação é comumente encontrada, devido a flutuações na temperatura e principalmente na composição do meio de cultura. Geralmente o uso de meio mínimo com $1 \%$ de glicose causa retardo na germinação.

Para a linhagem UI 203, foi feita a contagem dos núcleos dos conidios para confirmação da porcentagem de $25 \%$ e $1 \%$ de conídios bi e trinucleados no tempo zero. Após 4 horas de incubação, pode-se observar que a maioria dos germinantes da linhagem UI 203 possui 4 núcleos, porém poucos germinantes possuem tubos germinativos (Figura $1 F$ ), o que é característico dos germinantes selvagens que possuem 4 núcleos (Figura $1 \mathrm{C}$ ). $\mathrm{Na}$ amostra de 5 horas, é possivel ver vários tipos de germinantes, os que possuem 8 ou mais núcleos e estão em processo de formação do tubo germinativo e os que tem 8 núcleos dentro do conídio, o qual se expandiu isometricamente, sem contudo, diferenciar o tubo germinativo (Figura 1G). No tempo de 6 horas, predominam os germinantes com 16 núcleos, embora a maioria deles não possua tubo germinativo com extensão suficiente para acomodar todos estes núcleos, os quais não se distribuem regularmente na extensão do mesmo, sobrepondo-se uns aos outros. É interessante notar que cerca de $30 \%$ dos germinantes depositam um septo junto ao tubo germinativo mais curto, o que não é observado no selvagem.

A análise dos germinantes serviu também para o cálculo do indice mitótico. No mutante bncA1 este número é de $9 \%$ e na linhagem selvagem é $3 \%$. Este índice está de acordo com aquele obtido por Morris (1976), para linhagens selvagens. Na Figura1I, a seta dupla indica um núcleo em mitose.

O gráfico da Figura 2 mostra que o mutante deixa o bloqueio imposto pela dormência cerca 1 hora antes do selvagem. 


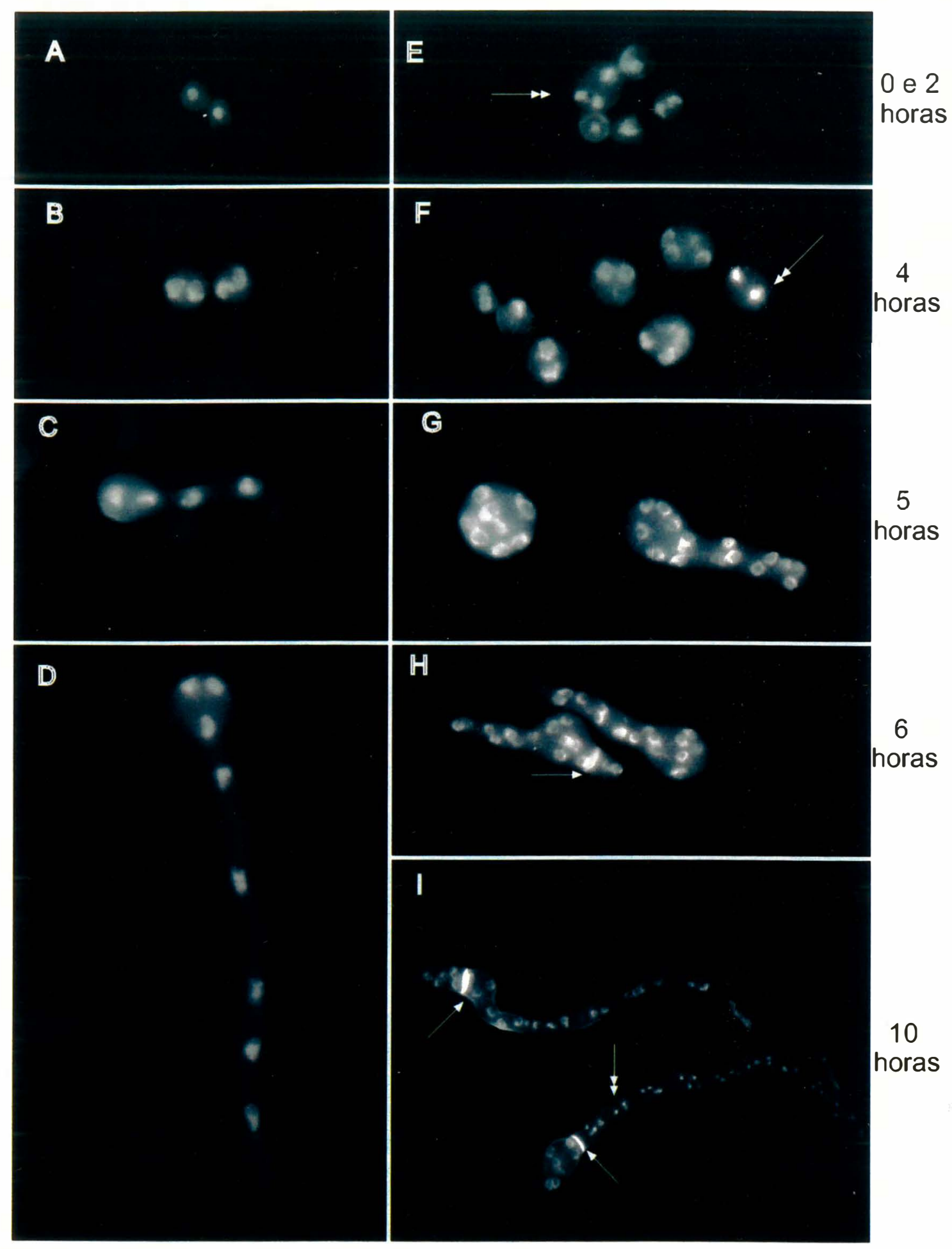

Figura 1: Linhagem selvagem UI 201 em diferentes tempos da germinação (A - D). Germinantes da linhagem mutante UI $203(E-I)$. Os tempos estão indicados na margem direita. As setas apontam os septos, e as setas duplas os núcleos em mitose. Os aumentos são de 400X para as micrografias $A$, E, F, G, H e I. Para as micrografias B, C, D, o aumento e de 630X. 


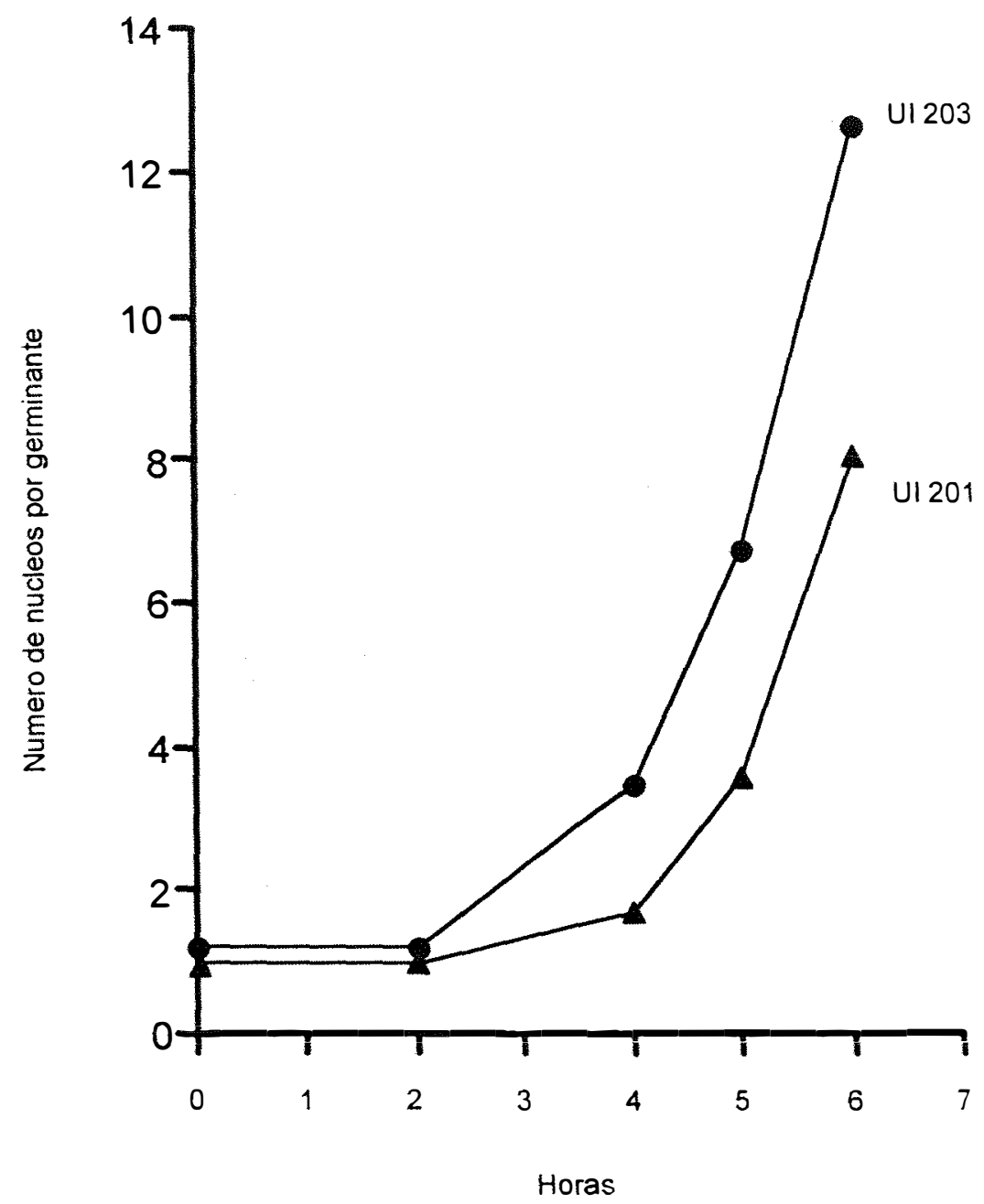

Figura 2: Cinética de divisão nuclear para a UI 201 (selvagem) e UI 203 (bncA1). Cada ponto do gráfico representa o número médio de núcleos por germinantes para um dado tempo, em cada linhagem. Foram analisados cerca de 200 germinantes para cada tempo. 
Talvez isso ocorra devido a diferenças na composição da parede celular do mutante, permitindo a absorção mais rápida de água e em função disso, a quebra mais rápida da dormência. É importante notar que o mutante possui uma variabilidade maior de germinantes, com relação ao número de núcleos. Geralmente para o selvagem, no tempo de 4 horas, a maioria dos germinantes possui 2 núcleos, mas mesmo assim foi possível observar uma porcetagem pequena de germinantes com 1 e 4 núcleos. Para o mesmo tempo, o mutante tem a maioria dos seus germinantes com 4 núcleos, bem como germinantes com 1, 2, 8, 14, 16 núcleos (Apêndice).

\subsubsection{Análise dos elementos internos da hifa}

Dando continuidade a caracterização da mutação bncA1, observou-se os compartimentos internos da hifa após cerca de 12 horas de crescimento. Este experimento foi realizado sobre lamínulas esterilizadas, com as linhagens $\mathrm{UI}$ 201 e UI 203, utilizando meio completo líquido YGMTV. Foi feita a coloração com DAPI/Calcofluor e observação em microscópio de fluorescência.

A Figura $3 \mathrm{C}$ mostra os compartimentos internos da hifa da linhagem selvagem (UI 201). Estes são delimitados por septos, os quais estão indicados pelas setas. Os compartimentos contém um número variável de 2 a 10 núcleos. Os núcleos do selvagem, estão em intérfase e apresentam-se bem distribuídos pela extensão da hifa. Estruturas análogas podem ser visualizadas para a linhagem UI 203 (Figura3A e 3B). A linhagem mutante possui um número superior de núcleos por compartimento. Estes posicionam-se de forma aleatória dentro da hifa; alguns parecem estar em mitose (seta dupla), outros em intérfase e muitos, parecem estar em processo de desintegração. A presença de núcleos em mitose, sugere que o bloqueio do ciclo celular imposto, normalmente, aos núcleos dos compartimentos mais velhos da hifa não está sendo respeitado. Normalmente, somente os núcleos presentes nos compartimentos que irão emitir ramificações da hifa ou desenvolver a haste do 


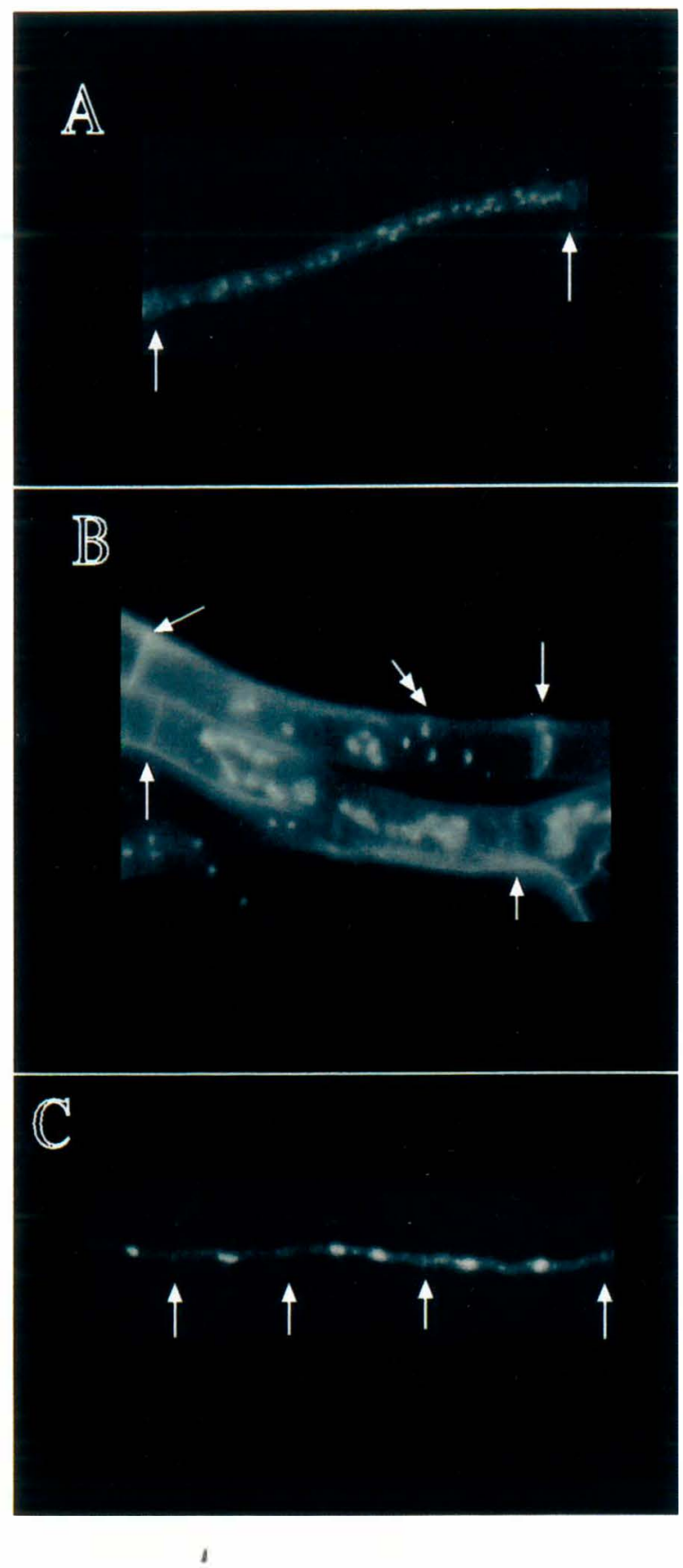

Figura 3: A e B são compartimentos da hifa, da linhagem mutante UI 203. A micrografia $C$ exemplifica elementos internos da linhagem selvagem UI 201. Aumentos de 400X para A e C e 630X para B. As setas apontam os septos e as setas duplas os núcleos fragmentados. 
conidióforo é que voltam a se dividir, caso contrário somente os núcleos na ponta da hifa se dividem (Rosemberg \& Kessel, 1967).

\subsubsection{Estudo da sensibilidade à drogas antimicrotúbulos}

A observação de que os núcleos dos elementos internos da hifa sofrem fragmentação, posicionamento irregular e morfologia anormal, sugere que esta mutação afeta a organização da rede microtubular. Para testar esta hipótese várias linhagens contendo a mutação bncA1 foram testadas quanto a sensibilidade frente a diferentes concentrações das drogas antimicrotúbulos Tiabendazol e Nocodazol. Estas duas drogas tem afinidade pela tubulina e conseqüentemente se ligam a ela, e não permitem que a as subunidades se associem formando o microtúbulo (Davidse, 1986). As linhagens escolhidas foram: UI 201 (selvagem) e UI 203 (bncA1); UI 204 (nimT23) e UI 205 (bncA1; nimT23 ${ }^{\text {TS }}$ ); as linhagens UI 212 e UI 211 são diplóides, heterozigota e homozigota para bncA1, respectivamente. $O$ experimento foi conduzido nas temperaturas de $33^{\circ} \mathrm{C}$ e $42^{\circ} \mathrm{C}$, pois os mutantes nimT23 tem crescimento permissivo e restritivo nestas duas temperaturas, respectivamente. Vale notar que a mutação bncA1 não altera o crescimento radial das colônias. As linhagens utilizadas neste experimento atingem crescimento radial médio de 30 $\mathrm{mm}$ em meio mínimo suplementado com os requisitos nutricionais adequados. A mutação nimT23 $3^{\mathrm{TS}}$ somente altera o crescimento radial à $42^{\circ} \mathrm{C}$.

Os resultados da Tabela 1 mostram que as linhagens que contém a mutação bncA1 apresentam redução média de $43 \%$ e 50\% no diâmetro das colônias na presença de Tiabendazol e Nocodazol, respectivamente. É interessante notar que existe uma variação entre as linhagens mutantes testadas. UI 203 tem redução de $44 \%$ e UI 205 apresenta diminuição de $60 \%$ no crescimento em relação à $U I 201$. Este resultado sugere que existe uma interação entre bncA e nimT. 
Tabela 1: Teste de resistência ao Tiabendazol (A) e Nocodazol (B), para as linhagens selvagens (UI 202, UI 204), mutantes bncA1 (UI 203, UI 205), e diploides, heterozigoto (UI 212) e homozigoto bncA1 (UI 211). As medidas representam a média de três repetições do diâmetro das colônias, dados em milímetros. (N/C, não cresce).

\section{(A)}

\begin{tabular}{ccccccc}
\hline \hline Linhagem & \multicolumn{2}{c}{$\begin{array}{c}\text { Tiabendazol } \\
4 \mathrm{ug} / \mathrm{ml}\end{array}$} & \multicolumn{2}{c}{$\begin{array}{c}\text { Tiabendazol } \\
\text { 5ug/ml }\end{array}$} & \multicolumn{2}{c}{$\begin{array}{c}\text { Tiabendazol } \\
6 \mathrm{ug} / \mathrm{ml}\end{array}$} \\
\cline { 2 - 7 } & $33^{\circ} \mathrm{C}$ & $42^{\circ} \mathrm{C}$ & $33^{\circ} \mathrm{C}$ & $42^{\circ} \mathrm{C}$ & $33^{\circ} \mathrm{C}$ & $42^{\circ} \mathrm{C}$ \\
UI 201 & $7,5 \pm 0,7$ & $30 \pm 7$ & $5 \pm 0,5$ & $28 \pm 1,5$ & $4 \pm 0,5$ & $18 \pm 1,7$ \\
UI 203 & $5,0 \pm 1,4$ & $23 \pm 1,4$ & $4 \pm 1,4$ & $18 \pm 0,7$ & $\mathrm{~N} / \mathrm{C}$ & $12 \pm 0,5$ \\
& & & & & & \\
UI 204 & $9,0 \pm 0$ & $\mathrm{~N} / \mathrm{C}$ & $8 \pm 0$ & $\mathrm{~N} / \mathrm{C}$ & $6 \pm 0,5$ & $\mathrm{~N} / \mathrm{C}$ \\
UI 205 & $3,0 \pm 0$ & $\mathrm{~N} / \mathrm{C}$ & $2,5 \pm 0,7$ & $\mathrm{~N} / \mathrm{C}$ & $\mathrm{N} / \mathrm{C}$ & $\mathrm{N} / \mathrm{C}$ \\
& & & & & & \\
UI 212 & $7,5 \pm 0,7$ & $16 \pm 0,7$ & $\mathrm{~N} / \mathrm{C}$ & $11 \pm 1,1$ & $\mathrm{~N} / \mathrm{C}$ & $6 \pm 0$ \\
UI 211 & $\mathrm{~N} / \mathrm{C}$ & $6,6 \pm 1,4$ & $\mathrm{~N} / \mathrm{C}$ & $7 \pm 2$ & $\mathrm{~N} / \mathrm{C}$ & $\mathrm{N} / \mathrm{C}$ \\
\hline
\end{tabular}

(B)

\begin{tabular}{ccc}
\hline \hline Linhagem & \multicolumn{2}{c}{ Nocodazol } \\
\cline { 2 - 3 } & \multicolumn{2}{c}{2 ug/ml } \\
UI 201 & $5,5 \pm 0,7$ & $6 \pm 0$ \\
UI 203 & $6 \pm 0$ & $4 \pm 0,5$ \\
& & \\
UI 204 & $10 \pm 0$ & N/C \\
UI 205 & $3 \pm 0$ & N/C \\
UI 212 & $6 \pm 0$ & $6 \pm 1$ \\
UI 211 & $4 \pm 0,7$ & N/C \\
\hline \hline
\end{tabular}


Com estes resultados foi possivel concluir que a mutação bncA1 confere sensibilidade às drogas que interferem com a polimerização dos microtúbulos.

\subsubsection{Análise dos efeitos da mutação bncA1 no conidióforo}

Com o intúito de reproduzir a análise do fenótipo de bncA1 no conidióforo (Pascon, 1994), fez-se observações desta estrutura em microscópio óptico de "contraste diferencial de interferência" (DIC) e foram feitas colorações com DAPI/Calcofluor e observações sob luz ultravioleta. As análises confirmaram que tanto as métulas quanto as fiálides são multinucleadas, apresentam crescimento alongado e assumem um formato mais parecido com a hifa verdadeira, do que o aspecto normal de pseudo-hifa (Figura 4). A Figura 10 mostra exemplos comparativos de conidióforos selvagens da linhagens FGSC26.

Uma vez que todas as estruturas, desde o conídio até as células reprodutivas foram analisadas sob o ponto de vista citológico, é interessante notar como as relações entre mitose, citocinese e crescimento celular nas linhagens bncA1 acompanham as tendências de cada tipo celular. Mirabito \& Osmani (1994), propõem que o comprometimento que existe entre crescimento celular, mitose e citocinese é muito rígido no conidióforo. Sempre que há mitose, há um crescimento celular especifico e obrigatoriamente há citocinese, garantindo desta forma o padrão uninuclear das células. Nos primeiros momentos da germinação este comprometimento é pouco rígido, o que garante o padrão filamentoso (Harris et al.,1994). Nos elementos internos da hifa, a obrigatoriedade entre estes 3 processos biológicos volta a ser um pouco mais rígido, porém ainda é permitido ter um número variável de 2 a 10 núcleos por compartimento (Harris, 1997). 


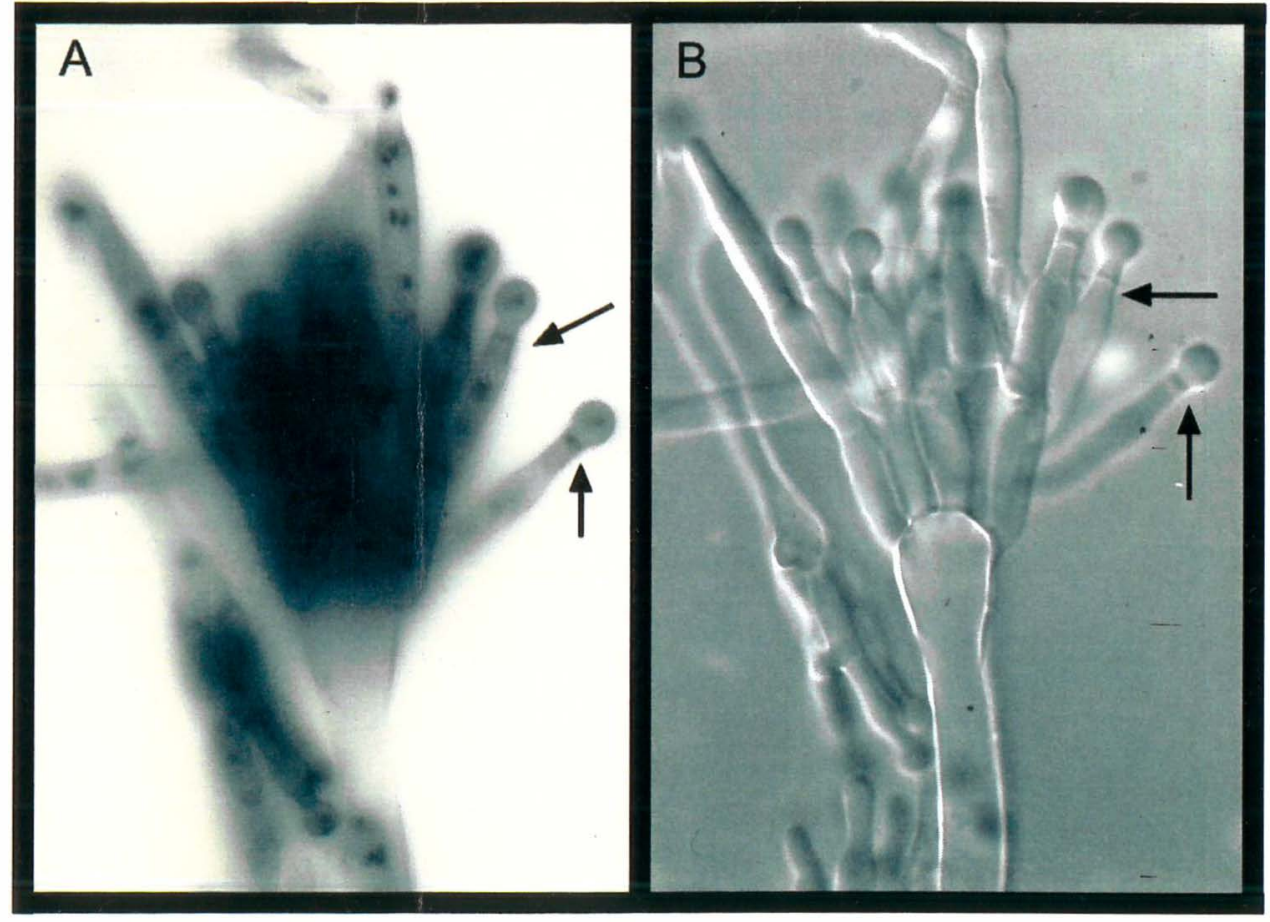

Figura 4: Micrografia A, conidióforo do mutante bncA1, linhagem UI 203. Coloração dupla com DAPI/Calcofluor. Micrografia B, DIC ("differential interference contrast"). As setas indicam os septos. Aumento de 630X. 
Nas linhagens bncA1, os germinantes tem 0 padrão de crescimento celular onde o tubo germinativo é mais curto, porém o número de núcleos não é menor. Além disso, o crescimento radial da colônia não é alterado (dados não apresentados). Isso mostra que a mutação afeta sutilmente 0 crescimento celular, mas como as relações entre mitose e crescimento celular não são estritamente coordenadas, a mitose não é afetada. Mais uma vez observa-se um certo grau de descomprometimento entre mitose, crescimento celular e citocinese. No caso dos compartimentos internos da hifa, é possivel observar que a obrigatoriedade dos três eventos é um pouco maior, uma vez que começa a haver descontrole no ciclo celular com proliferação da mitose e formação de compartimentos internos de tamanhos variáveis. Estas observações sugerem que a comunicação entre os 3 processos é mais ativa e que o decontrole em um deles gera resposta nos outros. Nos esterigmas, a relação núcleo/citoplasma precisa ser mais constante ainda, portanto, quando o ciclo celular fica desregulado, a célula responde imediatamente alterando o seu padrão morfogenético, isto é, as métulas e as fiálides assumem formato alongado e assumem características de hifa. Estas análises sugerem que bncA tem um papel fundamental no ciclo de vida de $A$. nidulans e a mutação neste gene afeta a mitose, crescimento celular e citocinese de forma diferencial, de acordo com o ambiente celular em que ela é analisada.

\subsubsection{Análise da freqüência de heterocários e de diplóides da linhagem bncA1}

A ocorrência de esterigmas multinucleados sugere 3 possibilidades. a) há migração de mais de um núcleo da vesícula para dentro da métula; b) que os núcleos continuam dividindo-se mais vezes que 0 programado nos esterígmas e no conídio ou, c) uma combinação dos dois eventos. PizziraniKleiner \& Azevedo (1986) já haviam relatado dados de heterocários que indicavam que mais de um núcleo migra para a métula. Com o objetivo de 
comparar os dados e de obter informações sobre a freqüência de diplóides no mutante bncA1, este experimento foi repetido para duas das linhagens usadas neste trabalho.

O experimento para calcular a freqüência de heterocários e diplóides foi feito utilizando-se uma linhagem amarela, com diversos marcadores auxotróficos, UI 206, e uma linhagem branca, UI 203, contendo a mutação bncA1 e marcadores auxotróficos contrastantes. Foi estabelecido um heterocário controle com as linhagens UI 206 e UI 204. Foram feitas diluições em série dos conidios coletados dos heterocários e inoculou-se $1 \times 10^{5}$ conídios em meio minimo livre de qualquer requisito nutricional. As colônias heterocarióticas foram identificadas pela capacidade de crescimento em mínimo e pela mistura de conídios com coloração dos dois parentais, isto é, amarelos e brancos. Identificou-se e quantificou-se também a formação de diplóides. A confirmação dos mesmos foi feita com base na coloração verde das colônias, e pelo tamanho superior dos conídios. Os resultados estão apresentados na Tabela 2.

Neste experimento as freqüências de heterocários e de diplóides foram de aproximadamente, 1 em $10^{3}$ e 1 em $10^{4}$, respectivamente. No cruzamento controle, não foi possivel encontrar nenhuma colônia heterocariótica, nem diplóide inoculando-se $1 \times 10^{5}$ conídios, porém os mesmos foram encontrados na freqüência de 1 em 107, de acordo com o descrito por Clutterbuck (1974). Isto prova que no cruzamento envolvendo o mutante bncA1, a alta freqüência de tais eventos é proveniente da formação de conídios binucleados. PizziraniKleiner \& Azevedo (1986) realizaram o mesmo experimento, e encontraram uma freqüência de heterocários de 1 em $10^{5}$. Esta diferença pode ser explicada considerando-se que a freqüência de conídios heterocarióticos é dependente do balanceamento do heterocário. Se houver uma proliferação maior de um dos parentais, devido a diferenças no inóculo ou na vantagem seletiva apresentada por algum tipo parental, haverá maior chance de dois núcleos iguais formarem um conídio binucleado, o qual não será capaz de crescer em meio seletivo. 
No entanto, nos dois casos os resultados mostram que há migração aleatória de mais de um núcleo para dentro da métula. Este resultado faz sentido considerando a microscopia do conidióforo, onde observa-se que as métulas e fiálides são multinucleadas (Figura $4 A$ e B). Porém este resultado não exclui a hipótese de que a caracterísitica multinucleada das estruturas componentes do conidióforo possa ser decorrente da divisão descontrolada dos núcleos.

Tabela 2: Número de colônias heterocarióticas e diplóides originárias do cruzamento entre uma linhagem selvagem, UI 206 e mutante bncA1, UI 203.

\begin{tabular}{cccc}
\hline Repetições & $\begin{array}{c}\text { Heterocários } \\
\text { (Colônias brancas } \\
\text { amarelas) }\end{array}$ & $\begin{array}{c}\text { Diplóides } \\
\text { (Colônias verdes) }\end{array}$ & Total \\
\hline 1 & 80 & 10 & 90 \\
2 & 53 & 9 & 62 \\
3 & 65 & 17 & 82 \\
Média & 66 & 12 & 234 \\
\hline
\end{tabular}

4.1.6. O gene bncA e a progressão do ciclo celular

O mutante bncA1 apresenta elevação no índice mitótico, o que sugere que a mutação afeta a fase $M$ do ciclo celular. Provavelmente, este alelo mutante causa um prolongamento da mitose, uma vez que não há bloqueio da progressão do ciclo. Além do alto índice mitótico, a desintegração dos núcleos dos compartimentos internos da hifa, a má distribuição nuclear, a migração de múltiplos núcleos para dentro dos esterígmas e a sensibilidade às drogas antimicrotúbulos, levam a crer que o gene bncA exerce funções relacionadas à motilidade nuclear. 
Morris (1976) nomeou as linhagens de $A$. nidulans, com alto indice mitótico, como "bim" ("blocked in mitosis"). O estudo destes mutantes desvendou vários componentes estruturais e regulatórios da mitose. Dentre eles pode-se citar: bimC (Enos \& Morris, 1990; Enos et al., 1991); bimG (Doonan et al.,1991), bimD (Denison et al.,1993; Denison \& May, 1994); bimA e bimE, os quais fazem parte do complexo promotor da anáfase ou ciclossomo (Lies et al.,1998).

A compilação das informações disponiveis não permitem ainda discernir exatamente se o gene $b n c A$ exerce sua função na composição do aparato mitótico ou no controle do ciclo celular. Porém, baseando-se nas análises de outros genes que tem fenótipos parecidos com este é possivel formular algumas hipóteses:

1. bncA poderia estar envolvido diretamente na montagem dos heterodimeros de tubulina e, conseqüentemente, afetar as fibras do fuso mitótico e os microtúbulos citoplasmáticos. Neste caso, o fenótipo de fragmentação nuclear, a sensibilidade ao Tiabendazol e Nocodazol, e a má distribuição nuclear, poderiam ser explicados pela conformação anormal dos microtúbulos. Um exemplo de um mutante que afeta a motilidade celular por meio da interação com os microtúbulos, é cdp1.1 de $S$. cerevisiae. Este apresenta super sensibilidade à Tiabendazol, resistência a Benomil, e produz até 100 vezes mais perdas cromossômicas do que o selvagem. Além disso, o mutante produz células binucleadas e multinucleadas em alta freqüência, causadas pela má orientação do fuso mitótico. Foi detectada a desorganização da rede microtubular citoplasmática, e por este motivo os núcleos não conseguem se posicionar corretamente dentro da célula (Foreman \& Davis, 1996). Os autores sugerem que este gene é essencial para divisão nuclear e segregação cromossômica. O mecanismo de ação da proteina CDP1 seria por interação direta ou indiretamente com a tubulina.

2. bncA poderia codificar uma proteina de associação aos microtúbulos (MAP: "microtubule-associated-protein"), ou uma proteina motora envolvida na 
segregação dos cromossomos. Em S. cerevisiae, duas proteinas do tipo MAP (Ase1p e Bik1p) são requeridas para a movimentação das fibras do fuso durante a anáfase e para a coordenação entre mitose e citocinese. Porém, precisam ser destruídas pelo APC/C (complexo promotor da anáfase/ciclossomo) para que haja saída da mitose e entrada em G1. Caso contrário, há atraso da mitose, com a persistência do fuso mitótico (Pellman et al.,1995; Juang et al.,1997). As proteinas do tipo MAP possuem um perfil no qual bncA1 poderia ser encaixado. $O$ atraso na mitose, a fragmentação nuclear e a sensibilidade às drogas antimucrotúbulos, são consistentes com as características da perda de função das proteínas MAP. A caracterização do arranjo do fuso mitótico no mutante bncA1 poderá a vir esclarecer esta hipótese. bncA poderia também ser uma proteína motora, como é o caso da quinesina mitótica codificada por bimC (Morris, 1976; Enos \& Morris, 1990). Mais uma vez os fenótipos causados pela mutação são consistentes com esta hipótese, principalmente a interação com Tiabendazol e Nocadazol. É provável que uma proteina motora, a qual se movimenta sobre os microtúbulos, seja afetada pelas drogas que causam a desestabilização dos mesmos. Isso explicaria também porque os núcleos são mal posicionados dentro da hifa. A clonagem e a dedução da seqüência de aminoácidos de bncA pode determinar se esta hipótese é verdadeira, uma vez que as proteinas motoras possuem o domínio correspondente ao motor celular conservado.

3. bncA poderia estar envolvido na organização do cinetocoro, como é o caso do bimD6 (Morris, 1976; Denison et al., 1993). Ou mesmo agir durante a condensação da cromatina. Como é o caso do mutante supressor de bimD6. A caracterização de sudA ("supressor de bimD") demonstrou que este gene é um modulador da condensação da cromatina. A mutação é capaz de alterar a cromatina, restaurando a ligação dos centrômeros às fibras do fuso mitótico. Tanto bimD6 quanto sudA1, causam fragmentação nuclear e sensibilidade aos compostos que perturbam o andamento do ciclo celular, como às drogas antimicrotúbulos (Holt \& May, 1996). 
4. Finalmente, o gene bncA poderia ser uma das subunidades do complexo promotor da anáfase, como é o caso de bimA e bimE (Morris, 1976; Engle et al.,1990; O'Donnell et al.,1991; Lies et al.,1998). Pelo que se sabe a partir do estudo de $A$. nidulans e de $S$. cerevisiae, o mal funcionamento dos componentes deste complexo pode alterar inúmeros aspectos da mitose, especialmente aqueles que são relevantes para a saída da mitose, como é caso da proteólise da ciclina-B e de Ase1p (Pellman et al.,1995; Zachariae et al.,1996; Juang et al.,1997; Irniger \& Nasmyth, 1997; Lies et al.,1998). Todos os fenótipos observados para o mutante bncA1 poderiam ser explicados pelo mal funcionamento de $A P C / C$, uma vez que a atividade deste complexo atinge os componentes estruturais e regulatórios da fase $M$ do ciclo celular, os quais são todos extremamente interligados.

Os dados apresentados mostram que o gene bncA desempenha uma função na progressão do ciclo celular em $A$. nidulans. Para determinar exatamente qual é esta função, são necessárias mais informações de natureza bioquimica sobre 0 produto deste gene. A seqüência de aminoácidos, pode desvendar alguns aspectos funcionais sobre bncA, a super expressão do gene, a localização da proteina e a interação desta com outros componentes conhecidos da progressão da mitose, podem vir a esclarecer exatamente onde, quando e como este gene funciona. Estas informações poderiam ser acessadas com a clonagem do gene bncA. No momento isto está em processo. Devido a sutileza do fenótipo, tem sido bastante difícil a clonagem por complementação direta da mutação bncA1. Na tentativa de contornar esta dificuldade duas estratégias estão sendo usadas. A primeira foi a clonagem da mutação hisA10. Esta mutação auxotrófica localiza-se no cromossomo IV à uma unidade de mapa da mutação bncA1. A clonagem foi feita usando-se o banco ordenado do cromossomo IV. Já é sabido que o cosmídio que complementa hisA10 não complementa bncA1. Porém a identificação e posicionamento deste marcador genético no mapa físico possibilitará a execução de um "chromosome walking" e desta forma espera-se encontrar o cosmídio que complementa a mutação 
bncA1 (dados não apresentados). A sensibilidade a droga Tiabendazol, além de ter sido muito útil para mostrar o envolvimento de bncA1 com a tubulina, também serve para enfatizar o fenótipo bncA1. Estão em progresso também experimentos para evidenciar a estrutura dos microtúbulos, bem como a localização da actina no mutante bncA1. Estes experimentos são fundamentais para o estabelecimento da função do gene bncA1. 


\subsection{Estudo do mutante aconidial aco586 ${ }^{T S}$}

\subsubsection{Clonagem e caracterização do gene aco586}

Yager et al. (1982) concluiu que o mutante $a c 0586^{T S}$, afeta o desenvolvimento assexual e sexual.

Tendo como objetivo estabelecer em qual aspecto do desenvolvimento do conidióforo este gene toma parte, delineou-se uma estratégia para clonagem de aco586. Para tanto, a linhagem UI 129, a qual possuia mutação aco586 ${ }^{T S}$, foi transformada com um banco genômico em cosmídio, o qual foi construído no Departamento de Microbiologia, Biologia Molecular e Bioquímica da Universidade de Idaho, por Karen Miller. A marca de seleção usada foi argB (Upshall, 1986).

Um total de 1.500 transformantes foram obtidose, dentre estes, 4 deixaram de apresentar o fenótipo aconidial na temperatura restritiva de $42^{\circ} \mathrm{C}$. Após a purificação de uma colônia transformante, o DNA genômico foi extraído e o cosmídio foi resgatado por meio do empacotamento do DNA do transformante. O extrato, resultante do empacotamento, foi usado para transfectar a linhagem $\mathrm{DH} 5 \alpha$ de $E$. coli. Vários clones resistente a ampicilina foram purificados e os DNAs cosmidiais de 4 deles foram extraidos em preparações de larga escala. Estes clones foram usados para transformar a linhagem UI 129 novamente. Dos 4 clones, apenas um voltou a complementar, em alta freqüência, o fenótipo acondial e a sensibilidada à temperatura. Este cosmídio foi denominado cos586.3.

Para localizar o gene aco586 na extensão do inserto do cosmídio cos568.3, o mesmo foi digerido com várias enzimas de restrição (BamHI, Hindlll, Xbal, Pstl, EcoRl, Sacl, Xhol, Kpnl, Sall). Estas digestões foram fracionadas em gel de agarose e transferidas para suporte sólido ("Southern Blot"). A sonda utilizada na hibridização foi obtida pela sintese da primeira fita de cDNA, a partir de "RNA poliAdenilado", isolado de cultura vegetativa da 
linhagem FGSC26. Após a síntese, o cDNA foi marcado com $\left[\alpha-{ }^{32} P\right.$ ]dCTP e usado como sonda no experimento de "Southern Blot" mencionado acima (dados não apresentados). Os resultados indicaram que a sonda hibridizou com uma banda de aproximadamente $13,5 \mathrm{~Kb}$, na digestão com BamHI, isto significa que este fragmento contém pelo menos uma ORF. As digestões com Hindlll e EcoRI, revelaram bandas de aproximadamente, $11 \mathrm{~Kb}$ e $6,7 \mathrm{~kb}$, respectivamente. As demais análises de restrição apresentaram múltiplas bandas que hibridizaram com o cDNA marcado radioativamente.

O próximo passo foi transformar a linhagem UI 129 com cos586.3 digerido com BamHI, Hindlll e EcoRI, separadamente. Apenas a digestão com BamHI foi capaz de complementar a mutação em alta freqüência, sugerindo que um dos fragmentos $\mathrm{BamHI}$ contém todas as seqüências necessárias, para a expressão do gene aco586 em trans. As demais digestões também complementaram a mutação, porém em baixa freqüência, indicando que os fragmentos Hindlll e EcoRI somente podem complementar a mutação por troca gênica. Esse resultado sugere que múltiplos sítios de restrição Hindlll e EcoRI clivam o gene internamente.

Os resultados provenientes da hibridização de cos586.3 com o cDNA marcado radioativamente e a análise da complementação da mutação com o cosmídio digerido com BamHI, indicaram que a banda de $13,5 \mathrm{~Kb}$ continha 0 gene aco586. Para confirmar esta hipótese, esta banda foi isolada do gel e foi usada para transformar a linhagem UI 129. A complementação aconteceu em alta freqüência, provando que o fragmento de $13,5 \mathrm{~Kb}$ continha todo $\circ$ gene (Figura 5). Esta banda não pode ser diretamente clonada em um vetor plasmidial, em vista das limitações impostas pelo tamanho do plasmídio. Geralmente, insertos grandes como este, causam uma queda drástica na freqüência de transformação. Para contornar este inconveniente, o fragmento BamHI de 13,5 Kb foi digerido com Xbal, produzindo 3 fragmentos, sendo o maior de $\sim 8 \mathrm{~Kb}$ (BamHIIXbal), um intermediário de $\sim 4 \mathrm{~Kb}$ (Xbal nas duas extremidades), e um menor de $1,675 \mathrm{~Kb}(X b a l / B a m H I)$. Os fragmentos de $8 \mathrm{~Kb}$ 
e 1,7 Kb foram clonados em pUC13, gerando os plasmídios pRCP1 e pRCP15, respectivamente. Ambos foram testados para complementação e apenas o fragmento maior complementou a mutação aco586. Foi feita a análise de restrição do plasmídio pRCP1, a qual possibilitou realizar deleções internas neste plasmídio, gerando $\mathrm{pRCP} 2$ e $\mathrm{pRCP} 3$, os quais também complementam a mutação aco586 (Figura 5A, painel 1).

Com esta análise de complementação foi possivel concluir que o menor fragmento genômico que complementa a mutação está contido em pRCP3, portanto, este contém a seqüência correspondente ao gene aco586 (Fig5A painel 1). Baseado neste fato, 0 fragmento de $\sim 2,4 \mathrm{~Kb}$ foi marcado radioativamente com $\left[\alpha-{ }^{32} \mathrm{P}\right] \mathrm{dCTP}$ e usado como sonda, na análise de um banco de cDNA, construído em bacteriófago $\lambda$ gt10. Neste experimento foram analisadas 560.000 placas de lise, das quais, 6 deram sinal positivo, após 1 hora de exposição em auto-radiografia (dados não apresentados).

Os clones positivos foram coletados e purificados até a obtenção de placas de lise isoladas. Os DNAs dos bacteriófagos foram isolados e digeridos com EcoRI. A clivagem com esta enzima liberou os braços, direito e esquerdo do bacteriófago $\lambda$ gt10 ( 23 e 9,5 Kb), e mais uma banda variável em tamanho, dependendo do clone. Dos 6 cDNAs positivos, 3 foram transferidos para vetor plasmidial de seqüenciamento "Bluescript $\mathrm{KS}^{+}$". A clonagem foi realizada no sítio de EcoRI, presente no sítio múltiplo de clonagem deste vetor plasmidial. A escolha destes 3 clones foi baseada no tamanho. Dois são de $1,414 \mathrm{~Kb}$ e outro de $4,004 \mathrm{~kb}$. A colinearidade entre os cDNAs isolados, o cosmídio $\cos 586.3$ e o fragmento genômico foi determinada por de análise de restrição (dados não apresentados).

Os fragmentos genômicos, usados na análise de complementação, serviram como molde para a preparação de sondas radioativas, marcadas com $\left[\alpha-{ }^{32} P\right.$ ]dCTP. Estas sondas foram utilizadas em experimentos de "Northern Blot", os quais foram preparados com "RNA poliAdenilado", provenientes de 
(A)

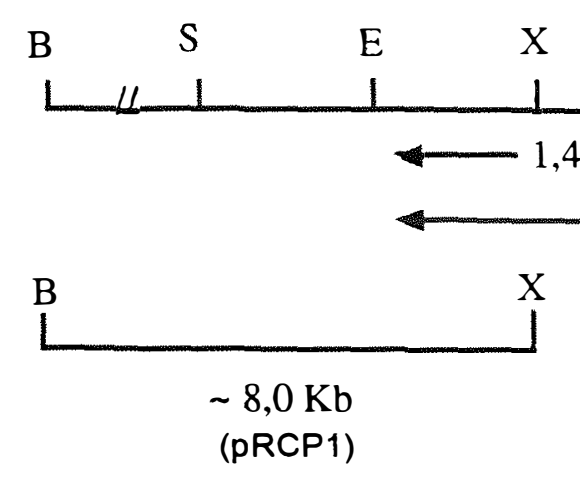
$4,004 \mathrm{~Kb}$ cDNA (pRCP14)

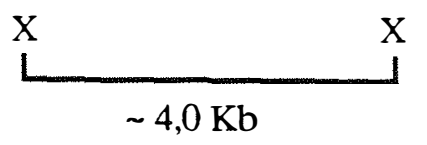

$+\quad+$ (pRCP1)
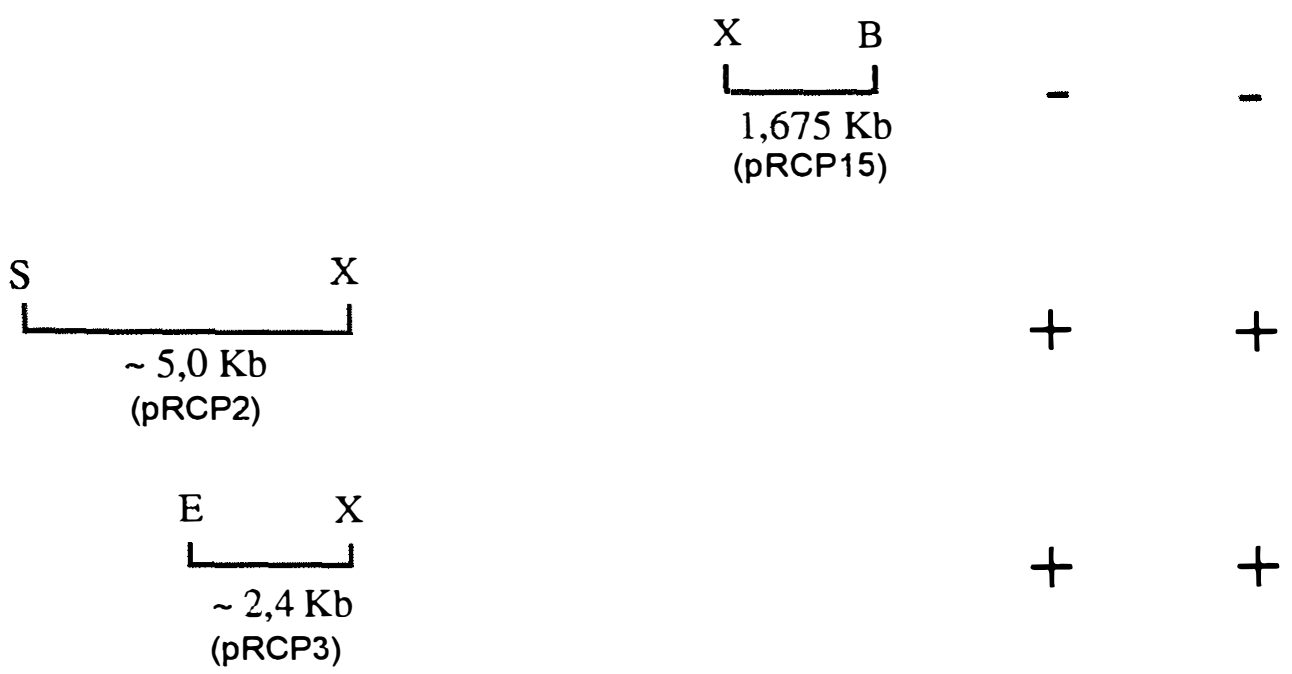

(C)

H $2,55,07,512,5$ hs.

(B)

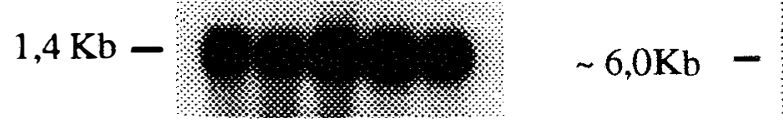

H $\quad 2.5 \quad 5.0 \quad 7.5 \quad 12.514 \mathrm{hs}$

Figura 5: (A) Mapa de restrição do cosmídio cos586.3. (1) fragmentos genômicos que complementam a mutação termossensivel aco586. (2) fragmentos usados como sonda em análise de "Northern Blot". + e - significa presença ou ausência de complementação da mutação no painel (1) e presença e ausência da banda de $\sim 6,0 \mathrm{~Kb}$ na análise de "Northern Blot" no painel (2). Análise da expressão do mRNA do gene aco586 (B) e argB (C) por "Northern Blot". B=BamHI; $E=E c o R I ; S=S a c l ; X=X b a l$. 
diferentes estágios de desenvolvimento de $A$. nidulans (Figura $5 \mathrm{~A}$, painel 2). Todos estes fragmentos, exceto pRCP15, evidenciaram um RNA mensageiro de tamanho aproximado de $6,0 \mathrm{~Kb}$, o qual é regulado diferencialmente durante o desenvolvimento (Figura $5 \mathrm{C}$ ). $O$ transcrito aco586 é mais abundante na hifa vegetativa, porém a abundância deste mRNA diminui a partir do momento em acontece a indução do desenvolvimento acontece, sendo praticamente inexistente com 12,5 e 14 horas. O "Northern Blot" da Figura 5B mostra o controle interno dos "RNAs poliAdenilados", usando como sonda o fragmento genômico argB (Upshall, 1986). A comparação entre os sinais apresentados pelos dois transcritos na Figura $5 \mathrm{~B}$ e $5 \mathrm{C}$, permite concluir que 0 transcrito correspondente ao gene aco586 tem baixa expressão.

A partir da complementação do mutante aco586, foi possivel realizar o isolamento e a caracterização do padrão de restrição do fragmento genômico e do cDNA parcial do gene aco586. A clonagem também tornou possivel estabelecer a abundância deste RNA mensageiro e identificar o padrão de transcrição do gene durante o desenvolvimento.

\subsubsection{Caracterização física do gene aco586}

Três clones distintos de cDNA, os quais hibridizam com pRCP1 e pRCP2, foram clonados em vetor plasmidial de seqüenciamento Bluescript/KS ${ }^{+}$, no sítio de EcoRI do sítios múltiplo de clonagem deste vetor. Estes plasmídios foram denominados pRCP5, pRCP6 e pRCP14.

A estratégia de escolha para o seqüenciamento foi "primer walking". Nesta metodologia, as primeiras seqüências foram obtidas com a utilização dos "primers" universais, "forward" e "reverse primer"". O conhecimento destas seqüências, possibilitou a sintese de "primers gene especifico", nas duas orientações ("forward" e "reverse"), o que possibilitou o seqüenciamento das duas fitas. 
A seqüência parcial de nucleotídeos do cDNA clonado em pRCP14, e a seqüência deduzida de aminoácidos, podem ser consultadas no Anexo $A$ e $B$.

O seqüenciamento e a comparação dos 3 clones, demonstraram que apenas pRCP5 possui uma cauda poliadenilada na extremindade 3', típica dos mRNAs de Eucariotos. Os outros dois clones não possuem esta estrutura, porém estes cDNAs tem início algumas bases após a cauda poliadenilada e daí para adiante tem identidade perfeita. É provável que a falta da cauda poliadenilada nos dois clones seja um artefato de clonagem. Nenhum dos cDNAs analisados quanto a seqüência representam o transcrito completo do gene aco586, em todos eles falta a extremidade 5'. A indicativa disto é o fato de que em toda a extensão destes cDNAs, o quadro de leitura mantém-se aberto. Este resultado é consistente com a análise de "Northern Blot", a qual sugere que 0 transcrito tem de cerca de 6,0 Kb. A falta de um cDNA completo, contendo o sítio de início da transcrição deste gene, impossibilita a caracterização da região 5 '.

Para contornar o problema da falta de um cDNA completo, foi feito o seqüenciamento do fragmento genômico contido no plasmídio pRCP15 e parte do fragmento genômico Xbal de 4,0 Kb (dados não apresentados). Estes dois fragmentos contém seqüências correspondentes a região promotora do gene aco586 e também o início da ORF. Porém, somente com o seqüenciamento do fragmento genômico é impossível determinar o início da transcrição, uma vez que é muito comum haver inserção de íntrons nesta região, o que dificulta a resolução da região 5'. Neste caso é necessário fazer o mapeamento por exonuclease S1 (obtenção de dados em andamento) e, desta forma determinar a presença de íntrons e o início correto da transcrição deste gene.

$O$ fato de que a mutação termossensivel pôde ser complementada com os cDNAs de 1,414 e 4,004 Kb, sugere que a extremidade 3' do gene codifica um domínio funcional da proteina. A seqüência de aminoácidos, deduzida a partir da seqüência de nucleotídeos do cDNA de $4.004 \mathrm{~Kb}$ (pRCP14), foi submetida a "Blast search 2.03" (www.ncbi.nih.gov/blast), com o objetivo de 
encontrar homologia com proteínas depositadas no banco de dados. $O$ acesso ao "Genbank" foi realizado via Internet por meio do NCBI ("National Center of Biotechnology Information"). Pesquisou-se todas as bases de dados não redundantes. A seqüência parcial de aminoácidos mostrou identidade de $57 \%$ a $72 \%$ com o domínio de transativação, presente em uma familia de fatores de transcrição do tipo "Zíper de Leucina" ("BZip"), denominada C/EBP ("ĆCAAT enhancer binding protein") (Umek et al., 1991). A Figura 6 mostra as identidades existentes nesta região, entre as espécies de $A$. nidulans, Rana catesbeiana e Homo sapiens. A proteina AC0586 possui também um possivel "Ziper de Leucina", porém este é atípico (ver Anexo B). Este tipo de estrutura é comum nas proteinas que precisam formar homodimeros ou heterodimeros para exercerem sua função, o que é típico dos fatores de transcrição (Ptashne, 1992; McKnight, 1995). Mais uma característica da proteina ACO586, é a presença de um domínio transmembrana, isto é, uma região da proteína que permite a sua associação com a membrana celular.

Além da semelhança de ACO586 com o domínio de transativação da familia de fatores de transcrição $C / E B P$, esta proteina também apresenta homologia com uma ORF de $S$. cerevisiae, a qual foi isolada dentro do projeto de seqüenciamento desta levedura. A comparação entre ACO586 e a ORF YDR141c (número de acesso pir//s51869) mostrou que estas possuem $51 \%$ de identidade. Os blocos de identidade aparecem ao longo de toda extensão das duas proteinas. É interessante notar aqui, que esta ORF também possui um domínio de transativação semelhante ao encontrado na família C/EBP's. Porém a identidade nesta região, entre $A$. nidulans e $S$. cerevisiae, é de $35 \%$, isto é bem menor do que a encontrada entre $A$. nidulans e $R$. catesbeiana (72\%) e $A$. nidulans e $H$. sapiens (57\%). A ORF YDR141c, também apresenta um "Ziper de Leucina" atípico, como a proteína $A C 0586$. Em ambas as proteínas esta região é extremamente rica nos aminoácidos Leucina, Isoleucina e Valina. Por último esta ORF codifica uma proteína que possui um "domínio transmembrana", assim como ACO586. 


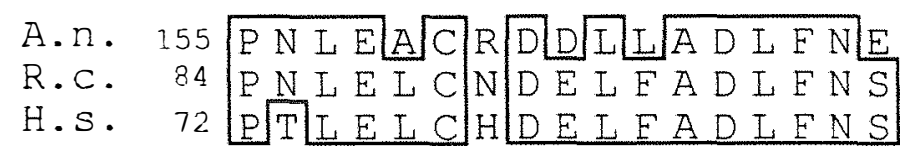

Figura 6: Identidade entre os resíduos de aminoácidos da região que define o domínio de transativação ("BBox"), da família de fatores de transcrição E/CBP. A.n.: Aspergillus nidulans; R.c.: Rana castebeiana; H.s.: Homo sapiens. Os números à esquerda representam a posição dos aminoácidos na seqüência.

A seqüência de aminoácidos codificada por aco586 possui uma série de motivos típicos de proteínas que sofrem fosforilação, como por exemplo: possui 2 sítios de fosforilação por proteína quinase dependente de CAMP e um sítio de fosforilação por proteína do tipo Tirosina quinase. Não é possível, neste momento, lançar nenhuma hipótese sobre a funcionalidade e nem sobre a real importância destes motivos. Modificações da proteína nesses domínios poderiam confirmar o papel que cada um deles pode desempenhar.

Finalmente, a análise da proteína permite levantar a hipótese de que o gene aco586 codifica um fator de transcrição. O que é bastante curioso na seqüência parcial de nucleotídeos aco586, é fato desta codificar uma proteína grande para um fator de transcrição. No entanto, fatores de transcrição de tamanhos maiores ocorrem, como é o caso de Notch, descrito em $D$. melanogaster e em mamíferos. Esta proteína, é na realidade, um receptor transmembrana que possui um domínio extracelular, mas que também é capaz de ativar a transcrição de genes no núcleo. Notch é ativado na sua porção extracelular por um "ligante", que neste caso é um fator de crescimento. Esta interação ativa a proteólise de uma região específica da proteína Notch, a qual tem o seu domínio intracelular libertado da associação com a membrana, podendo entrar no núcleo e ativar a transcrição de genes. A capacidade de atuar como fator de transcrição é dependente da ligação de Notch com outros fatores de transcrição (Kopan \& Turner, 1996; Weinmaster, 1997; Schroeter et 
al., 1998). É importante notar também que o gene Notch está envolvido com os processos de desenvolvimento e diferenciação e responde a estimulos gerados por fatores de crescimento.

A proteina ACO586 possui alguns fatores que se encaixam nesta hipótese, como o domínio transmembrana e a presença de uma região com caracterísiticas de fator de transcrição. Para provar esta hipótese seria necessário, em primeiro lugar realizar a imuno-localização da proteína pelo uso de anticorpos monoclonais. $E$, posteriormente, provar que ACO586 realmente é capaz de ativar a transcrição. Para tanto seria necessário realizar géis de retardo mostrando que ACO586 se liga a seqüências especificas de DNA e desta forma tem sua mobilidade retardada. Seria interessante também deletar 0 possivel domínio de transativação e observar o fenótipo produzido (obtenção de dados em andamento). Seria informativo também fusionar o gene aco586 com o promotor alcA e expressá-lo em levedura, contendo um elemento "CCAAT enhancer" fusionado a um gene repórter, como lacZ.

\subsubsection{A deleção do gene aco586}

É possivel que a mutação aco586 ${ }^{\mathrm{TS}}$ seja o resultado da troca de uma base na região codificadora do gene, alterando a conformação da proteina, o que impediria a estabilidade desta em temperaturas mais elevadas. Portanto, não se pode descartar a hipótese de que a mutação termossensivel possa produzir um fenótipo diferente daquele causado pela completa inativação do gene.

Em vista disso, foi delineado um experimento para interromper o gene aco586 e desta forma torná-lo inativo. Para isso o cDNA de $4,004 \mathrm{~Kb}$ foi clonado no vetor plC19R/EcoRI (pRCP16), eliminando completamente o sítio múltiplo de clonagem deste vetor. Este plasmídio foi digerido com EcoRV, o qual cliva dentro do inserto, linearizando pRCP16. Foram ligados "adaptadores/BamHI" às extremidades abruptas criadas pela digestão com 
EcoRV. À este sítio artificial de BamHI, criado dentro do inserto, foi ligado um fragmento de $1,8 \mathrm{~kb}$, contendo o gene $\arg B$ digerido com BamHI (Figura 7). $O$ plasmídio contendo a construção descrita, foi denominado pFSB.

Esta construção foi transformada na linhagem selvagem FGSC89. Duas classes de colônias foram isoladas desta transformação: aquelas que assemelhavam-se ao tipo selvagem e as que apresentavam baixa esporulação assexual. Foram selecionados 9 transformantes para análise de "Southem Blot", para comprovar o tipo e o local da integração ocorrida em cada caso. Os DNAs destas linhagens transformantes foram extraídos, digeridos com EcoRI, transferidos para suporte sólido e hibridizados apenas com o inserto contido no plasmídio pRCP6 (Figura 5A). As linhagens que mantiveram o gene aco586 íntegro, apresentaram uma única banda de $6,7 \mathrm{~Kb}$ que hibridizou com 0 fragmento de 1,414 kb usado como sonda. Esta banda foi idêntica àquela observada para a linhagem controle, FGSC26, a qual não foi transformada (Figura 7A). O evento de troca gênica, entre o gene aco586 e o inserto de pFSB, foi identificado pelo desaparecimento da banda de $6,7 \mathrm{~Kb}$ e o surgimento de uma nova banda de $8,5 \mathrm{~Kb}$ (Figura 7D). Finalmente, a integração do plasmídio pFSB no locus do gene aco586, foi identificado pelo surgimento de duas bandas (7,1 e 5,4 Kb), as quais hibridizaram com a sonda (Figura $7 \mathrm{C}$ ).

Foi possivel também correlacionar o padrão de bandas com o fenótipo. Os transformantes que mantiveram a banda de $6,7 \mathrm{~Kb}$ continuaram apresentando fenótipo selvagem. As linhagens com inserção do plasmídio todo e as linhagens que sofreram troca gênica, apresentaram fenótipo aconidial, semelhante ao mutante termossensivel.

A realização deste experimento de "Southern Blot" permitiu a escolha da linhagem $\Delta a c 0586.17$ para análise detalhada do fenótipo. Esta linhagem foi selecionada, pois teve o gene aco586 inativado por recombinação homóloga entre a seqüência genômica e o plasmídio pFSB. 
(A)

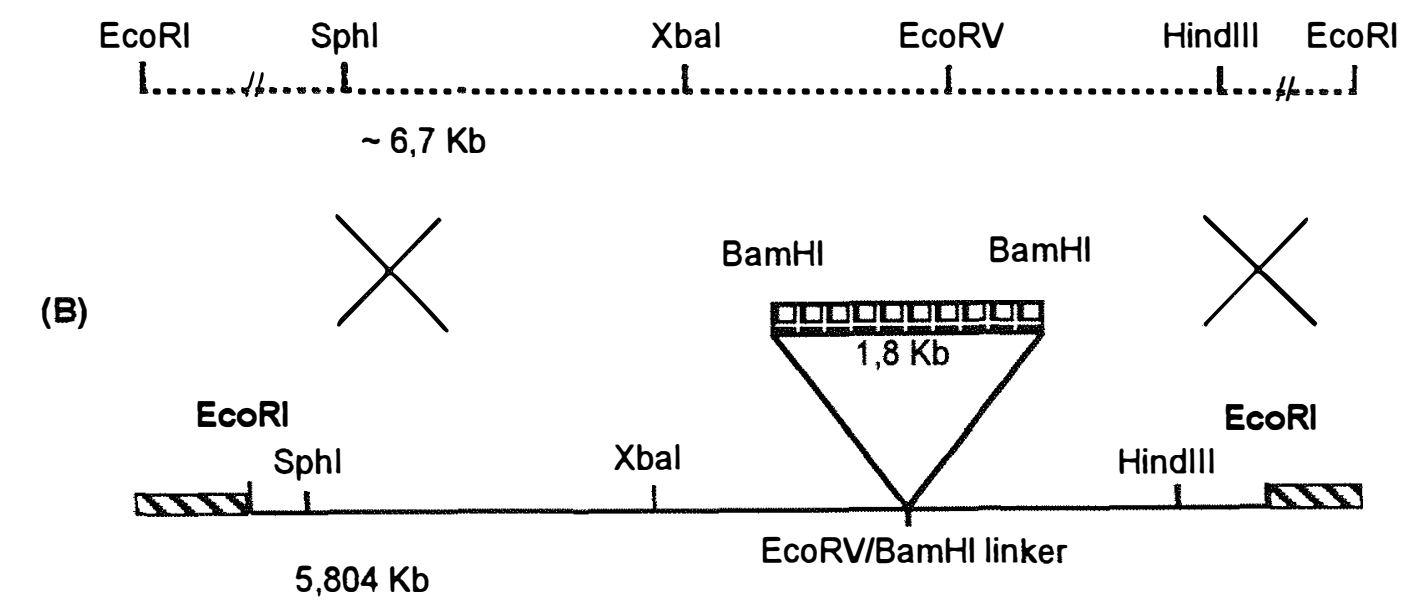

(C)

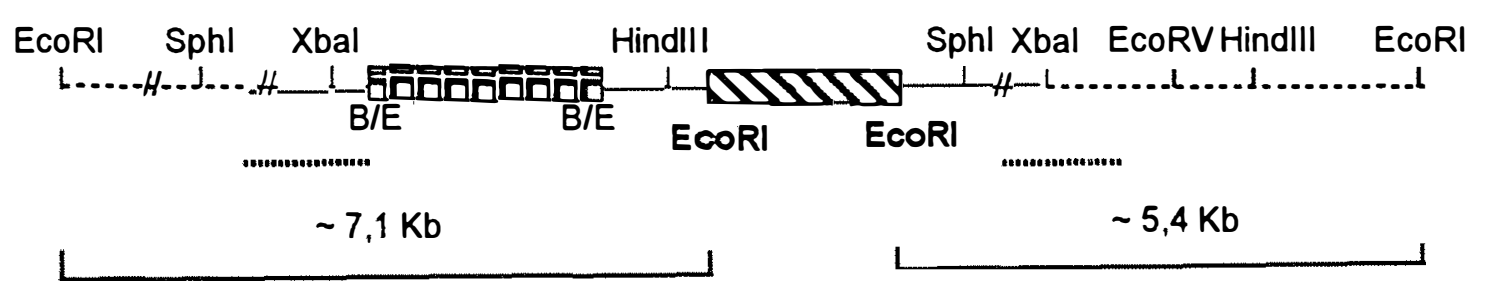

(D)

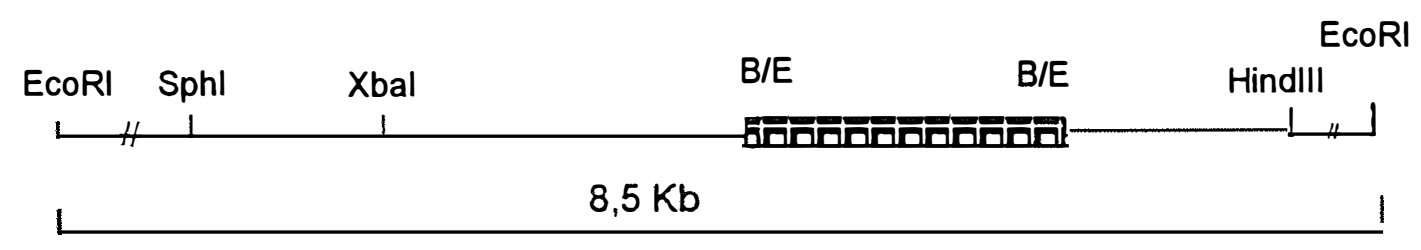

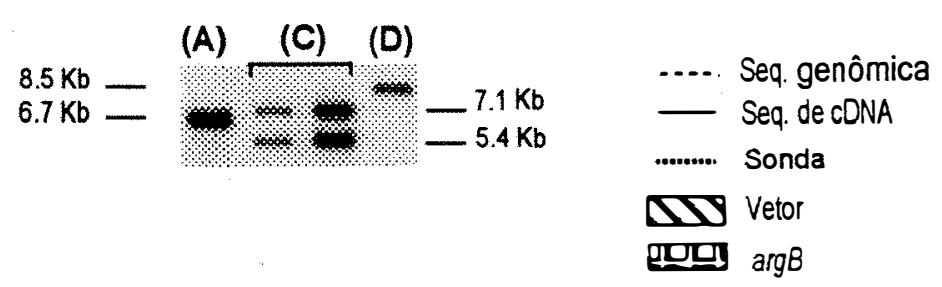

Figura 7: Representação esquemática da inativação do gene aco586. (A) fragmento genômico EcoRI de 6,7 Kb. (B) plasmídio pFSB conten do o CDNA interrompido por argB. (C) integração do plasmídio pFSB no genoma por simples crossing-over (duas repetições). (D) troca gênica por duplo crossing-over entre o plasmídio pFSB e o locus aco586. Os sítios de restrição EcoRI em negrito são artificiais. 
Foi realizado experimentos de "Northern Blot" para confirmar a inativação do gene aco586. Os RNAs totais da linhagem $\triangle a c 0586.17$ e FGSC26 foram extraidos e fracionados em gel de agarose-formaldeido, transferidos para suporte sólido, e hibridizados com com o inserto do plasmídio pRCP6. FGSC26 conservou a banda de aproximadamente $6,0 \mathrm{~Kb}$ correspondente ao transcrito do gene aco586. A linhagem inativada $\Delta a c 0586.17$ não apresentou esta banda, provando que o gene foi realmente inativado pela inserção de $\arg B$ (dados não apresentados).

4.2.4. Os efeitos da inativação do gene aco586 na conidiogênese

A observação da linhagem $4 a c 0586.17$ ao microscópio estereoscópico demonstrou que há uma redução drástica na quantidade de conidios produzidos, o que dá coloração marrom à colônia. Na linhagem FGSC26 os conídios tomam completamente a placa dando a colônia um aspecto aveludado de coloração verde.

A forma escolhida para quantificar a redução da capacidade de conidiogênese foi a contagem dos conídios. Para este experimento foram usadas as linhagens FGSC26 e a linhagem $\triangle a c 0586.17$, a incubação foi feita à $37^{\circ} \mathrm{C}$ por 5 dias. Foram feitas 3 repetições para meio completo (YGMTV) e para meio mínimo. Após este periodo os conídios foram coletados em Tween 80 , diluidos e contados em câmara de Neubauer. Os resultados podem ser vistos na Tabela 3.

Tanto a linhagem controle, quanto a linhagem $\Delta a c 0586$, produziram mais conídios no meio completo do que no meio mínimo. Porém, em ambos os meios de cultura a linhagem portadora do gene inativado produziu apenas $3,7 \%$ e $3,5 \%$ dos conidios produzidos pela linhagem selvagem FGSC26, respectivamente (Tabela 3 ). 
A baixa produção de esporos pode ocorrer porque a conidiogênese inicie-se tardiamente ou que ela ocorra em ritmo mais lento. Para responder a estas perguntas foi delineado um experimento, no qual, a produção de conídios da linhagem selvagem e da linhagem inativada foi monitorada durante o tempo. Foram avaliados 6 periodos de tempo, com 24 horas de intervalo entre cada um deles, totalizando 144 horas. Os conídios foram coletados das placas, diluídos e contados. Os resultados podem ser visualizados no gráfico da Figura 8 .

Pressupondo-se que apenas 0 início da conidiogênese seja afetada, as curvas deveriam começar em pontos diferentes, porém deveriam ter o mesmo padrão. A comparação das curvas desenhadas para a linhagem inativada e selvagem, indicam que a conidiogênese de $\Delta a c 0586$ inicia-se depois da conidiogênese da linhagem FGSC26, uma vez que com 24 horas foi possivel encontrar cerca de $4 \times 10^{4}$ conídios no selvagem e na linhagem inativada nenhum conídio pode ser contado. Além disso, as curvas possuem padrões muito diferentes. A curva da linhagem inativada não acompanha a curva da linhagem selvagem, o que sugere que a conidiogênese na linhagem $\Delta a c 0586$ é mais lenta do que no selvagem.

A viabilidade dos conídios também foi avaliada. Para isso, foram coletados conídios das linhagens $\triangle$ aco586 e FGSC26. Os mesmos foram filtrados, lavados, contados e diluidos o suficiente para germinarem 100 colônias por placa de meio mínimo. Este experimento foi conduzido com 3 repetições. Os resultados estão apresentados na Tabela 4. 
Tabela 3: Quantificação dos conídios produzidos pela linhagem FGSC26 e $\triangle$ aco586.17 em meio de cultura completo (YG) e em meio definido (MM).

\begin{tabular}{c|c|c}
\hline \hline & YG & MM \\
\hline FGSC26 & $4 \times 10^{8}$ & $1 \times 10^{8}$ \\
& $5 \times 10^{8}$ & $1 \times 10^{8}$ \\
& $4 \times 10^{8}$ & $2 \times 10^{8}$ \\
\hline Média & $4,3 \times 10^{8}$ & $1,3 \times 10^{8}$ \\
\hline aco586.17 & $2 \times 10^{7}$ & $2 \times 10^{6}$ \\
& $2 \times 10^{7}$ & $5 \times 10^{6}$ \\
& $1 \times 10^{7}$ & $7 \times 10^{6}$ \\
\hline Média & $1,6 \times 10^{7}$ & $4,6 \times 10^{6}$ \\
\hline \hline
\end{tabular}

Tabela 4: Viabilidade dos conídios da linhagem portadora da inativação do gene aco586 e da linhagem selvagem FGSC26

\begin{tabular}{c|c|c}
\hline \hline Repetições & FGSC26 & 4aco586 \\
\hline \hline 1 & 89 & 59 \\
2 & 83 & 62 \\
3 & 94 & 65 \\
\hline Total de conídios & 300 & 300 \\
semeados & & \\
\hline Total de conídios & 266 & 151 \\
germinados & & \\
\hline Viabilidade & $89 \%$ & $56,7 \%$ \\
\hline \hline
\end{tabular}




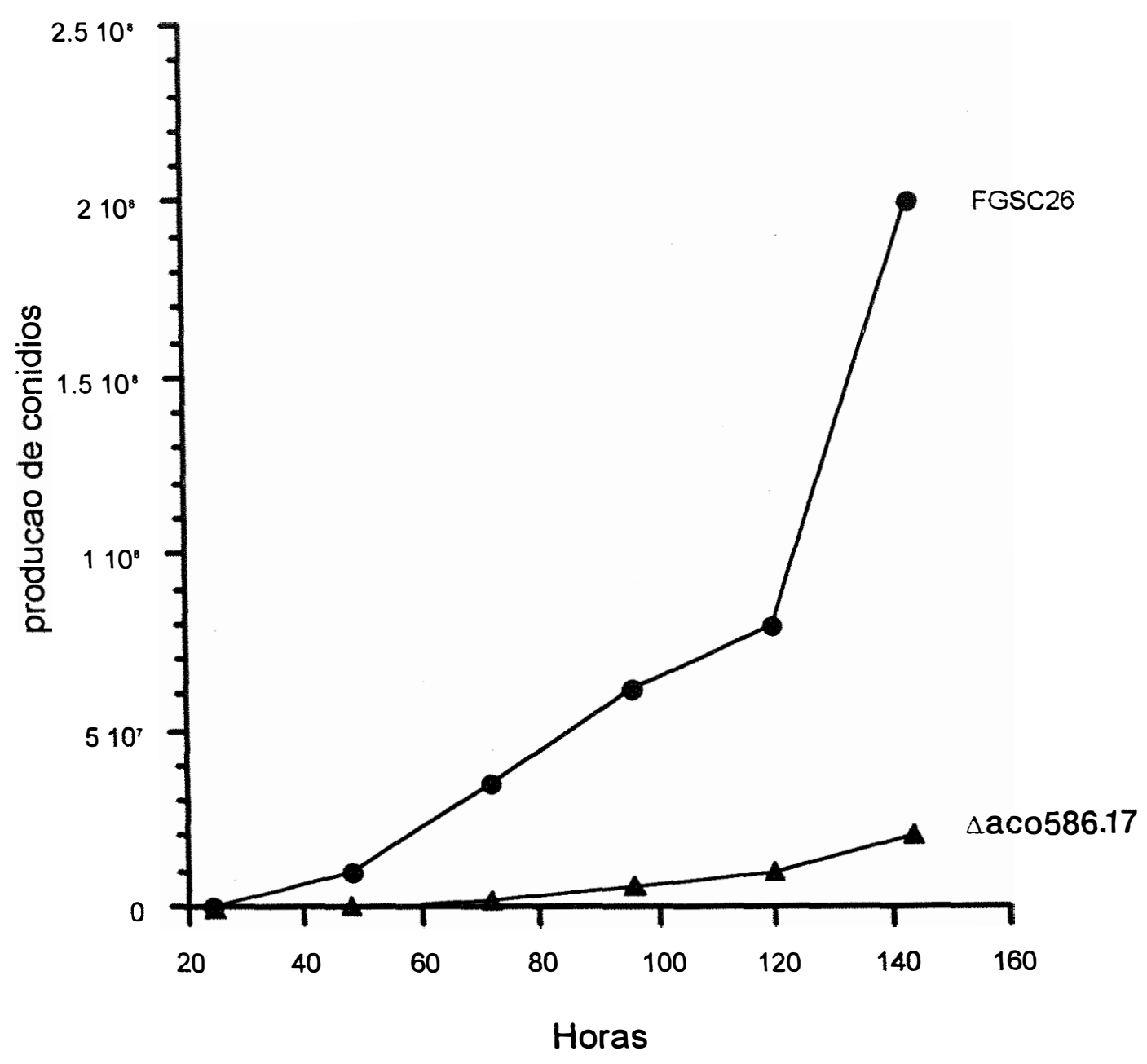

Figura 8: Gráfico mostrando a cinética de produção de conídios das linhagens FGSC26 e $\Delta a c 0586.17$. As amostras para contagem dos conídios foram coletadas com $0,24,48,72,96,120$ e 144 horas após a inoculação. Os dados originais do gráfico se encontram no Apêndice. 
Os dados da Tabela 4 comprovam que a inativação do gene aco586 causa inviabilidade de $43,3 \%$ dos conídios. A coloração destes conídios com o corante DAPI, mostrou que cerca de $20 \%$ destes são anucleados (dados não apresentados). Foi observado também que cerca de $50 \%$ destes conídios são de tamanhos muito variados e possuem morfologia anômala (Figura 9A e B). Esclarecendo a alta porcentagem de conídios inviáveis que nunca chegam a germinar e formar uma colônia.

4.2.5. Os efeitos da inativação gênica durante a germinação do conídio

O próximo passo na caracterização da inativação do gene aco586 foi o acompanhamento da germinação da linhagem $\Delta$ aco586 e FGSC26. Este experimento foi realizado como descrito no item 4.1.1., com a diferença que neste caso, usou-se meio mínimo, o que causa um atraso no início da germinação, isto é, com 5 horas de incubação $80 \%$ dos germinantes possuem 2 núcleos. Não foi possivel observar nenhuma diferença entre o padrão de germinação de FGSC26 e $\Delta a c 0586.17$ (dados não apresentados). Isto sugere que nestas condições de cultura este gene não desempenha nenhuma função nesta fase do ciclo de vida do fungo $A$. nidulans.

4.2.6. Os efeitos da inativação de aco586 na morfogênese da hifa vegetativa e no conidióforo

Foram realizadas colorações de núcleo e parede celular com DAPI/calcofluor e microscopia de fluorescência para observação das hifas e conidióforos. Não foi observado nenhum tipo de anomalia com relação a morfologia nuclear. $O$ índice mitótico da linhagem $\Delta a c 0586$ é igual ao da linhagem FGSC26, isto é, de $4 \%$. Não há fragmentação nuclear, e a distribuição nuclear é normal (dados não apresentados). 
As Figuras 9C, 9D, e 9E exemplificam a morfologia da hifa vegetativa predominante na linhagem $\Delta a c 0586.17$. A maior parte do tecido vegetativo é formado por este tipo de hifa, a qual lembra a pseudo-hifa, e possui padrão de septação anômalo, isto é, os elementos da hifa parecem brotamentos que formam uma constrição na ponta, ao invés de depor um septo. No transformante $\Delta a c 0586.17$, esta estrutura pode ser vista tanto na superfície do meio de cultura, quanto no interior do substrato. Esta estrutura vegetativa é observada no selvagem, porém raramente. Na linhagem FGSC26 esta hifa não cresce horizontalmente na superfície do meio de cultura, ela invade verticalmente o meio adentrando-o, e portando não é observada na superfície da colônia. Para observar este tipo de hifa no selvagem, é necessário retirar parte do substrato, esmagá-lo e então é possivel observá-la entremeada no ágar.

Não foi possivel encontrar na literatura nenhuma referência descrevendo este tipo celular no tecido vegetativo de $A$. nidulans. Em S.cerevisiae a diferenciação celular na forma de pseudo-hifa, a qual invade o substrato, pode ser induzida pela falta de nitrogênio (Gimeno et al., 1992). Em C. albicans este mesmo tipo celular também é comum e está relacionado com a forma invasiva e patogênica desta levedura. As condições de crescimento são determinantes para o modo de crescimento de $C$. albicans, sendo que, meios de composição pobre e baixas temperaturas contribuem para a forma de pseudo-hifa. Esta espécie á capaz de formar hifa verdadeira, induzida pela presença de soro em meio sólido ou líquido (Odds, 1988). Vários genes são conhecidos por serem responsáveis pela alternância ente crescimento leveduriforme e filamentoso em espécies dimórfica, como $S$. cerevisiae, ou polimórfica, como $C$. albicans.

Curiosamente, a proteina STUA faz parte de uma família de fatores de transcrição envolvidos na indução do crescimento em forma de pseudo-hifa (Miller et al., 1992; Gimeno et al., 1992; Gimeno \& Fink, 1994; Stoldt et al., 1997). É sabido que a homologia funcional de STUA com os outros membros desta família de fatores de transcrição, reside no fato de que esta proteína 
confere o caráter de pseudo-hifa, observado nos esterigmas primários e secundários de A. nidulans (Miller et al., 1992; Dutton et al., 1997).

Foi realizado o acompanhamento microscópico da conidiogênese das linhagens FGSC26 e $\Delta a c 0586.17$. As observações foram feitas a partir de amostras coletadas de indução sincronizada e de amostras retiradas de colônias crescidas diretamente sobre o ágar. No caso da indução sincronizada, as análises foram feitas com 5:00, 7:30, 10:00 e 12:30 horas de indução. $\mathrm{Na}$ quantificação dos fenótipos observados, foram consideradas 300 estruturas componentes do aparato reprodutivo assexual, para cada tempo analisado. Para a linhagem FGSC26, o desenvolvimento ocorre sincronicamente. Após 5 horas é possivel observar vesículas com os brotamentos das métulas. Com 7:30 horas observa-se métulas maduras, já com as fiálides formadas. E com 10 e $12: 30$ horas $80 \%$ dos conidióforos já estão completamente formados.

Para a linhagem inativada $\Delta a c 0586.17$, o desenvolvimento do aparato assexual é assincrônico. Com 5 horas de desenvolvimento há formação de um número de vesículas que é $50 \%$ inferior àquele observado no selvagem. A maior parte destas vesículas são muito pequenas, algumas possuem métulas, as quais brotam em número reduzido e de forma desorganizada no ápice da vesícula (Figura 9F a 9l). Há predominância deste tipo em todos os tempos após a indução, porém ocasionalmente é possivel encontrar alguns conidióforos selvagens, estes são em freqüência bastante reduzida (10\%). No decorrer dos próximos tempos os conidióforos continuam a se desenvolver, cerca de $30 \%$ deles formam as estruturas típicas encontradas no selvagem, porém há perda da sincronia do desenvolvimento, sendo que mesmo nos tempos mais avançados, como por exemplo, após 12:30 horas, ainda existe um número grande de vesículas e métulas sendo formadas, o que não acontece no selvagem, uma vez que o desenvolvimento foi sincronizado. Este resultado é consistente com $\circ$ gráfico da Figura 8 , ० qual sugere que o desenvolvimento ocorre em ritmo mais lento desde $o$ início. 
A falta de sincronia do desenvolvimento dos conidióforos da linhagem $\Delta a c 0586.17$, pode ser detectada também por meio do padrão assincrônico de brotamento das métulas. É muito comum nesta linhagem o aparecimento de esterígmas primários de vários tamanhos, como pode ser visto nas Figuras 9G, $9 \mathrm{H}$ e 91 .

Nestas preparações foi possivel observar que $60 \%$ dos conidióforos formados são anões (Figura 9J, 9K, 9L, 9M), assemelhando-se aos conidióforos do mutante stuA1 (Miller et al., 1992). O tamanho da haste é variável, podendo atingir cerca de 1/3 do tamanho do selvagem, ou menos (Figura 9J, 9K, 9L e 9M). Este fenótipo lembra muito aquele apresentado pela linhagem UI 91, a qual possui uma deleção de parte do promotor da gene stuA. UI 91 expressa somente o transcrito que é regulado de acordo com o desenvolvimento, astuA. Esta deleção remove cerca de $2 \mathrm{~kb}$ da seqüencia promotora do gene stuA, incluindo a parte do promotor que contém as seqüências UAS ("upstream activation sequences" ou "enhancers"). A linhagem UI 91, produz conidióforos anões, porém ao contrário de $\triangle$ stuA, UI 91 é capaz de diferenciar métulas e fiálides (Wu \& Miller, 1997).

A título de comparação, a Figura 10 mostra algumas fases do desenvolvimento do conidióforo selvagem (FGSC26) e do seu produto final, o conídio.

O fenótipo descrito acima, sugere que o gene aco586 poderia inflenciar a transcrição dos componentes regulatórios do desenvolvimento. Para comprovar esta hipótese, os RNAs da linhagem $\triangle a c 0586.17$ e FGSC26 foram transferidos para suporte sólido e hibridizados com uma sonda preparada com o DNA do gene brlA. Foram usados RNAs de cultura vegetativa, e de culturas induzidas com 5 horas, 7 horas e meia e 12 horas e meia de desenvolvimento. Os resultados mostraram claramente que brlA não produz o transcrito $\beta$, na ausência do gene aco586, às 12 horas e meia do desenvolvimento. Para o 

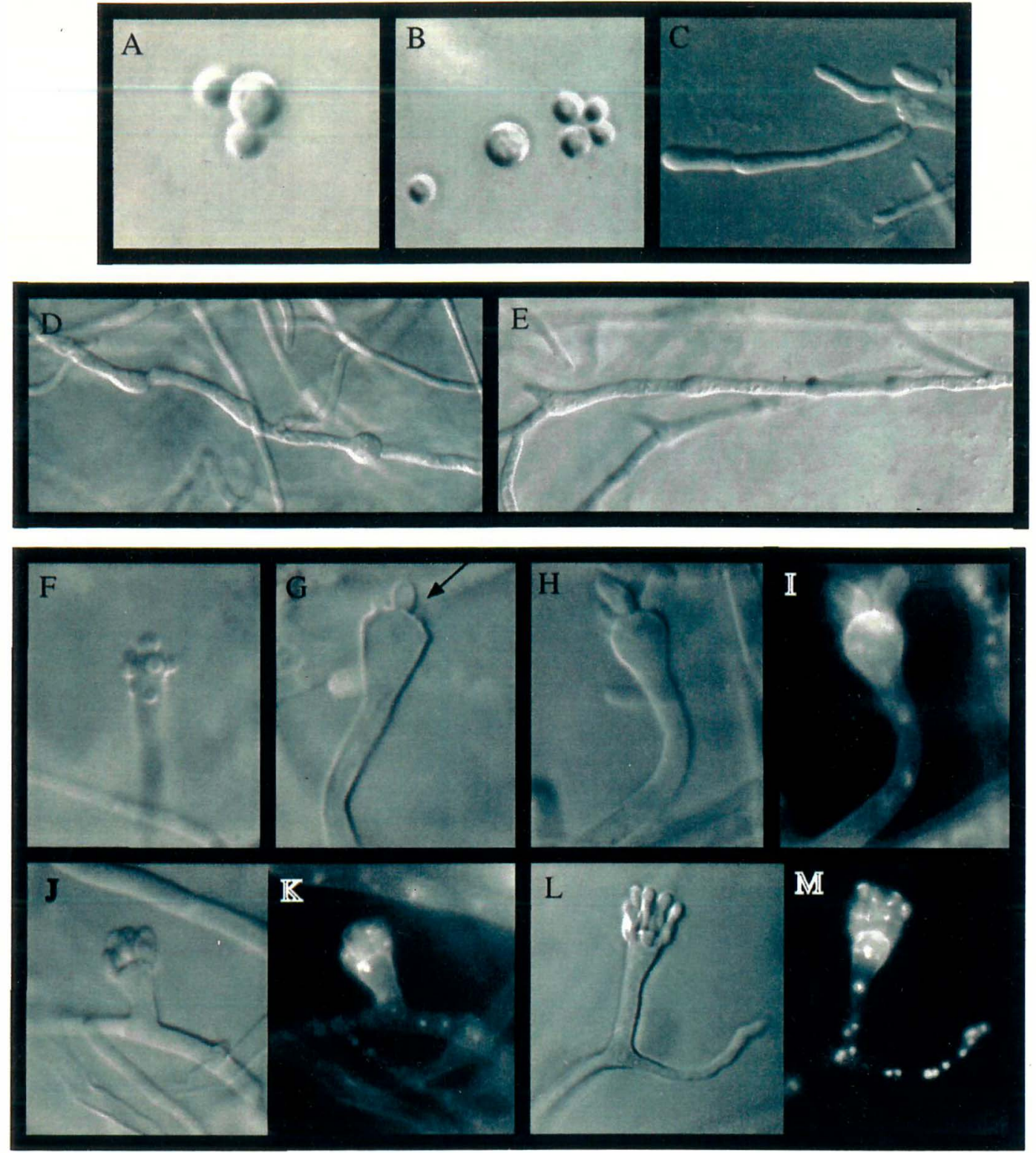

Figura 9: Micrografias da linhagem $\Delta a c 0586$. (A) e (B) conídios de tamanhos variados, DIC, aumento de $800 X$. (C), (D) e (E) representação da hifa vegetativa, DIC, aumento de 400X. (F) a (M) exemplos representativos da morfologia dos conidióforos da linhagem inativada, DIC e DAPI/Calcofluor. Aumentos de $400 \mathrm{X}$ e $630 \mathrm{X}$. A seta chama a atenção para a assincronia de brotamento da métula. 

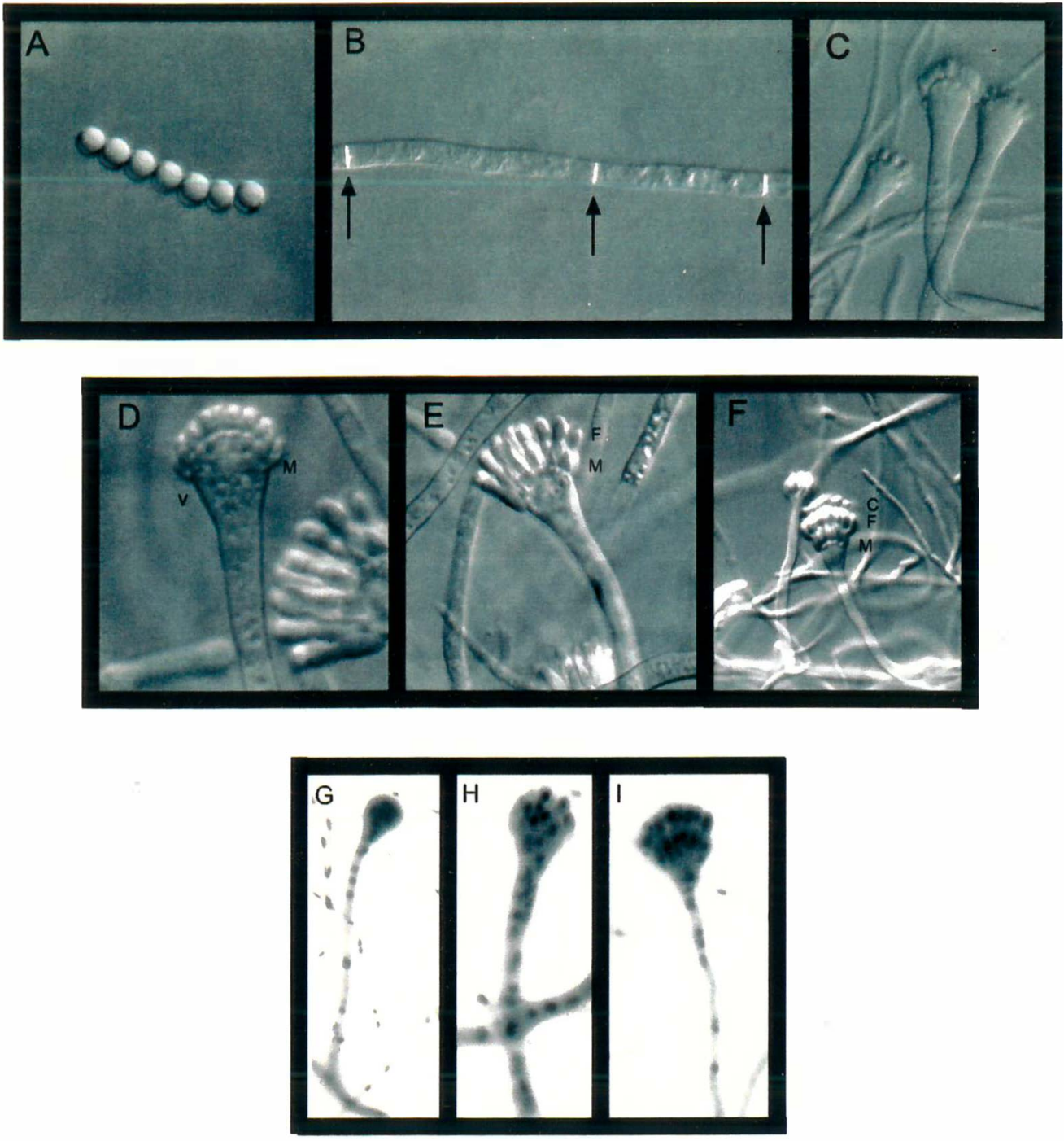

Figura 10: Micrografias da linhagem selvagem FGSC26. (A) cadeia de conidios, DIC, aument de $800 X$. (B) hifa vegetativa com septos indicados por setas, DIC, aumento de 630X. (C), (D), (E) e (F), vários estágios de desenvolvimento do conidióforo, DIC, aumento de 400X, 630X e 800X. (G), (H), (I), principais estágios de desenvolvimento do conidióforo, coloração com DAPI/Calcofluor, microscopia de fluorescência, aumentos de 400X e 630X. 
restante dos tempo, estes mRNAs aparecem em quantidades inferiores ao do selvagem (dados não apresentados).

A linhagem inativada é incapaz de diferenciar as estruturas relacionadas ao ciclo sexual em $A$. nidulans. A linhagem controle, FGSC26 produz cleistotécios após 7 dias de incubação à $37^{\circ} \mathrm{C}$ sob baixa tensão de oxigênio, porém a linhagem $\Delta a c 0586.17$ forma apenas algumas células Hülle e nunca chega a formar cleistotécios, mesmo após 14 dias de incubação.

\subsubsection{O gene aco586 e o seu papel na morfogênese de $A$. nidulans}

A caracterização física do gene aco586 foi o primeiro passo e o mais importante para elucidar sua função. Os resultados apresentados neste trabalho, indicam que este gene codifica uma proteina que possui homologia com a familia de fatores de transcrição, E/CBP, os quais possuem afinidade por seqüências do tipo UAS, ativando a transcrição de genes sob o controle de "enhancers". Pelo menos 7 genes, membros desta familia são conhecidos. Em todos os casos a transcrição só pode ser ativada se houver homo ou heterodimerização. Isto é possivel, uma vez que os fatores de transcrição E/CBP são proteinas do tipo "BZip", isto é, possuem um "Ziper de Leucina", o qual permite a dimerização (Wedel \& Ziegler-Heitbrock, 1995).

Muito tem sido especulado sobre o papel biológico dos E/CBP's. Sabe-se que em mamíferos são expressos em vários tecidos, e tem papel relevante na diferenciação do adipócito (Wedel \& Ziegler-Heitbrock, 1995; Constance et al., 1996). A atividade deste fator de transcrição causa o bloqueio da proliferação mitótica e desencadeia a expressão de genes específicos do adipócito, causando a diferenciação terminal deste tipo celular. Portanto, esta familia de ativadores da transcrição tem sido envolvida no balanço entre crescimento celular e diferenciação em animais superiores (Umek et al., 1991).

CHOP, é um membro dos E/CBP's que responde ao estresse celular, causando o bloqueio do crescimento e indução da diferenciação. Este fator de 
transcrição torna-se ativo por meio da fosforilação de dois resíduos de Serina (Ser78 e Ser81). A proteína p38, a qual faz parte de uma cascata de transdução de sinal do tipo MAP/Quinase, é a responsável pela fosforilação de CHOP. A inibição de p38 causa a incapacidade de resposta ao estresse, mediado por CHOP. Portanto este fator de transcrição é o elo de ligação entre a cascata de transdução de sinal MAP/Quinase, que é ativada pelo estresse, o crescimento celular e a diferenciação (Wang \& Ron, 1996).

O fenótipo causado pela inativação de aco586 mostrou que este gene está envolvido na restrição do crecimento vegetativo e na indução da diferenciação celular, assim como os fatores de transcrição E/CBP's. As observações que levaram a esta conclusão são:

1) Proliferação anormal do tecido vegetativo, como mostram as observações microscópicas;

2) Retardo e assincronia do desenvolvimento do aparato reprodutivo assexual e alta taxa de inviabilidade dos conídios.

3) Alteração no padrão de expressão do fator iniciador do desenvolvimento, 0 gene brlA.

4) A incapacidade de realizar o ciclo sexual.

A compilação destes dados, permite a formulação de uma hipótese para o funcionamento do gene aco586, como um fator de transcrição. A proteína AC0586 poderia modular a transcrição dos genes que determinam a redução da proliferação vegetativa e a diferenciação do conidióforo, como é o caso do gene flbA (Yu et al., 1996; Lee \& Adams, 1994b). Supondo que flbA não está sendo transcrito em níveis adequados, a proliferação vegetativa pode se prolongar inapropriadamente. A expressão insuficiente de flbA poderia causar a baixa expressão de brlA e consequente redução no desenvolvimento assexual.

Para confirmação desta hipótese será necessário fazer o monitoramento da expressão de flbA, o qual deverá ter baixos níveis de expressão na ausência de aco586, caso esta hipótese esteja correta. A atividade de GTPase, que regula a proteína FADA, também deve ser diminuída na ausência de aco586, 
uma vez que esta é a forma como flbA atua para regular negativamente a proliferação vegetativa comandada por fadA (Adams et al., 1998). Pode-se considerar também a possibilidade de que aco586 regule brlA diretamente, ligando-se aos elementos regulatórios deste gene e modulando a sua transcrição.

É importante mencionar também, que a falta da proteina aco586, provavelmente, afeta a expressão do gene stuA. A informação que sugere esta interação, é proveniente das observações microscópicas da linhagem inativada $\Delta a c 0586.17$. Um grande número de conidióforos, apresentam fenótipo idêntico a linhagem UI 91, a qual possui a maior parte do promotor do gene stuA deletado (Wu \& Miller, 1997). UI 91, assim como $\Delta$ aco586.17, diferem da linhagem $\triangle s t u A$ por desenvolverem métulas, fiálides e uma cadeia curta de conídios, o que não é observado na linhagem $\triangle$ stuA. É possivel que aco586, se ligue a elementos regulatórios no promotor de stuA, de forma a elevar a expressão do mesmo. Assim, é possível que a falta de aco586 cause fenótipo semelhante a deleção dos elementos aos quais ele se liga, normalmente.

Pode-se considerar também a possibilidade de que stuA e aco586 realizem um círculo regulatório. O seqüenciamento da região promotora de aco586, sugeriu esta interação. Foram encontrados 3 elementos responsivos a stuA nesta região (dados não apresentados).

É sabido que stuA é responsável por conferir complexidade ao conidióforo, por meio da moderação da expressão dos genes que dirigem a diferenciação terminal dos conídios uninucleados, a partir da hifa vegetativa multinucleada (Dutton et al, 1997). Para isso, regula negativamente brlA e possivelmente aco586, adequando seus niveis de expressão. Dois argumentos contam a favor deste modelo de regulação. O primeiro deles é a presença de "Elementos responsivos a stuA" no promotor de aco586 (dados não apresentados); e a segunda é a queda nos niveis do transcrito aco586 após a indução do desenvolvimento, que coincide com a elevação nos niveis de expressão de stuA. Porém esta hipótese ainda está por ser testada. 
A caracterização física, genética e citológica de aco586 mostrou que este gene afeta vários aspectos da morfogênese em $A$. nidulans e influencia várias fases do ciclo de vida deste fungo filamentoso. Desde o estabelecimento do padrão de crescimento vegetativo até o desenvolvimento do ciclo assexual e sexual.

A continuidade deste trabalho deverá ser direcionada para a obtenção de evidências diretas de que aco586 age como fator de transcrição sendo capaz de se ligar a "enhancers" ou seqüências especificas da região promotora e, desta forma dirigir a expressão de genes. Neste trabalho, foram fornecidas evidências circunstanciais de que aco586 codifica um fator de transcrição, relacionado à inibição do crescimento celular e indução da diferenciação.

A super expressão da proteína ACO586 também deve ser feita, e pode vir a fornecer informações valiosas. Se a hipótese lançada aqui for correta espera-se que a indução ectópica do gene aco586 sob o controle do promotor alcA provoque o desenvolvimento precoce em condições de cultura submersa.

A inativação da ORF YDR141c em S. cerevisiae, é uma estratégia bastante atraente para estudar a função do gene aco586. É possivel que a mutação neste gene torne a levedura incapaz de responder aos estímulos que levam a diferenciação sexual. Uma vez que esta espécie de levedura é um modelo biológico mais simples e portanto os resultados são mais facilmente interpretados, a condução dos experimentos neste organismo pode proporcionar um grande avanço no estudo da função do gene aco586.

Finalmente, este trabalho mostra que aco586 está envolvido na morfogênese. A caracterização da expressão de outros genes envolvidos na diferenciação assexual, como flbA, stuA, e abaA, na ausência de aco586, poderá contribuir para o entendimento da diferenciação do conidióforo em $A$. nidulans. 


\section{CONCLUSÕES}

Com os estudos de caráter genético e citológico sobre o mutante bncA1, conclui-se que este gene está envolvido na progressão do ciclo celular em $A$. nidulans. Foi possivel concluir que o gene bncA atua especificamente durante a mitose e exerce funções relacionadas à motilidade nuclear. Portanto, as anomalias causadas pela mutação bncA1 durante 0 desenvolvimento são decorrentes da incapacidade de movimentação correta dos núcleos.

O estudo realizado com o gene aco586 permitiu a conclusão de três pontos principais:

1) aco586 é um regulador da morfogênese do conidóforo.

2) a seqüência de aminoácidos codificada por este gene tem homologia com proteínas que compõe uma família de fatores de transcrição do tipo "Bzip", as quais se ligam à "enhancers" do tipo "CCAAT" ativando a transcrição de genes relacionados com a diferenciação celular.

3) aco586 é um membro da principal via regulatória do desenvolvimento e modifica a expressão de brlA, que é um componente essencial da morfogênese em $A$. nidulans. 


\begin{abstract}
ANEXO A
Sequência de nucleotídeos do cDNA de 4004 kilobases, correspondente ao gene aco586.
\end{abstract}

\begin{tabular}{|c|c|c|c|c|c|}
\hline & GG & GA & $A A$ & CTA & \\
\hline GTGGTG & ACTTTGTTGA & CAGGGTTATT & GATTGATCGC & GстTTTCTCC & STCTGA \\
\hline GAAC & TCAGTAAATG & CCGTCGAT & CTGCTTGAC & CGTCCAGGTT & CTGCGATCTT \\
\hline AAATA & CATCAGTTCT & GATCGAAG & AGAAACAGT & TGC & СТСС \\
\hline & GG & ГTTGAT & $\mathrm{AT}$ & $A A C$ & $\mathrm{TC}$ \\
\hline & GCGTGCAATG & CGCTAAATC & ATACCAGAG & GACTCAATC & ATCGT \\
\hline$A A$ & AAGCTTCCTA & ATCGCGCAT & ГTGCGGGAC & AAAGGCTCT & CAT \\
\hline $\mathrm{AT}$ & ATTCAAGCGT & SACAGTCGA & $\triangle A A C A$ & СTTCATTCT & SAC \\
\hline GTCG & ACAACGATAA & СТСТА & TGTATCCAC & ATTGGGCT & ACTATATCAC \\
\hline & $\mathrm{CT}$ & $\mathrm{CC}$ & GA & GC & $\mathrm{CTC}$ \\
\hline & $\Gamma \mathrm{C}$ & $\mathrm{AGC}$ & GT & GGAATC & TCAGT \\
\hline G & GACCAC & CGAC & ATCACGTCC & AATGTTTA & $\mathrm{CTCC}$ \\
\hline $\mathrm{CA}$ & TACCA & AGGA & GGAGGCTGGT & & TTC \\
\hline $\mathrm{AC}$ & CATGGTACAT & $\mathrm{ACC}$ & $A A G A A C$ & $\mathrm{CT}$ & CGGC \\
\hline CTCT & TATCATTCTT & TTGA & ACGGCCGCTT & CACTGTCT & $\mathrm{ATT}$ \\
\hline AGGG & $\mathrm{TC}$ & GGT & TG & GG & STC \\
\hline & GTT & TC & $A G$ & $5 \mathrm{C}$ & $A A A$ \\
\hline & ACTTTTG & TGG & TGTATCCCCA & GACT & GG \\
\hline TTTC & GAGACGA? & TTCT & GGGGGCACTT & CG & GAT \\
\hline TTACG & CAAACGATGG & ACAG & CAGGCGGCAC & ACGCTI & CTTC \\
\hline ATGCCGAA & GCCCCAAGCC & AGT & TTTCAG & :TTCGC & AGATTGTGAG \\
\hline CAAG & TCTGGTA & GAA & CGCAGAGGAG & CAAA & $\mathrm{AGCA}$ \\
\hline $\mathrm{C}$ & ATG & $\mathrm{TT}$ & $\mathrm{TC}$ & $A G$ & CGG \\
\hline $\mathrm{CA}$ & CTTCTTGTCG & TTTA & TTCTATGCTT & CGAGGGTG & GC \\
\hline TCCAAGCG & GCATTGATCG & $\triangle \mathrm{CTCCT}$ & CGCTGTGCTA & AAGGCTC & TTTCCCAAGC \\
\hline ACCG & CCGCCTCCTA & ССТAA & GCACCAAAGA & GGGGGCTCTC & GCGAGAAATT \\
\hline $\mathrm{CC}$ & тстстTстст & AAG & CGACAAGCCA & $\mathrm{AT}$ & CCGTGCTGCT \\
\hline & GAGCCTC & $\mathrm{STT}$ & GCCTG & ГСАAА & TCAGCTCTCC \\
\hline & GCGATAATCG & CGGAT & CATGCTGCTT & GTGAA & TCССAATCTA \\
\hline CTACGTGC & ATCTTCCAAA & TTCTGCTGAC & TTTGGTGGAT & GCCTGC & GGGAGATTAG \\
\hline ACAGTCATAC & ACGAATCTCC & AGTCCGCAT T & CGAAAAGACA & SAAGGTTGGC & CCAAAGATCG \\
\hline CCGAGCAG & ACCACTATAT & CССТCCTGAC & TGGTTTTGAG & ACGTGTATTG & CAGCTGCTCA \\
\hline AGCGCLI & CTCATGG & AGTAAATGC & GCCGGCAGCC & AGAGTCCGG & ATCAAACCCA \\
\hline & & ГTCGGGTGT & ITCGCGTCT & $\mathrm{CC}$ & $\mathrm{AT}$ \\
\hline ר & התם & $\mathrm{T}$ & $\mathrm{T}$ & $A G A C$ & \\
\hline
\end{tabular}




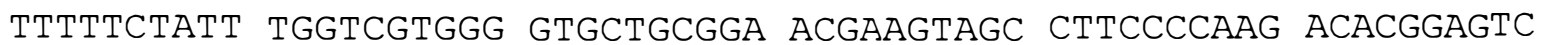
AAtAgCGTCG TTCCAATATA CATCACTGCG AATGCGgAAC AGATCTCGCC GGATtCTCGA

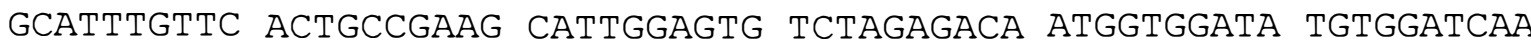
GTCTGACAGg GATACATCGC CTCTGATCTT TAATCTCCTT CACACTTTGG ACGGGTCTCG TCCAAGATTG CCATTCCAGC TATCTTCAAT GCTATCTATA CACGAACAAA TCCTGCCGCG CTTGACCCCA GCCGCAAGTC GACGATCAAC GGCCTTTAAC AGAGATTGAG TTAGCGGATT CCTGGTAACT TACGCTAGGT CTCTTGACGA TGATGTCCTG GATAAGATAT GGATAGACTG CACGACTTTC CTGCGAGATG TACTAAGCAA CCCTTTCCCT CACAGGCAGA TCCTCCCGCG GCTAGTTGA TTTGCTGCCA TCTTGgGCGT AAAACTTGA AACACGAACT TTGgCGAAGA TCGTCGGATG AgAAAgGAgT TGgGgGATGT GATACTGCGC CTCCTCACCG CCATCTTTAC AAgTAAACCC ATGGGCTTTA CGCAgGAACA AgGgCTTCTA GgTCGTGCCT CATtAgACTA TGATAGTTCA TCGATCCAGC GCATAGgGCC AGATGAtATg TTAAgTATCC TTGTTGCGTC

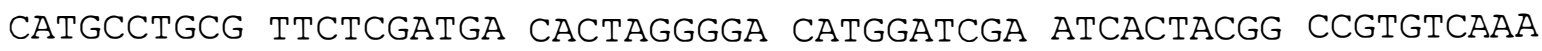
TATTTCTACC AATATTATCG GGCCGTTCAT ACGTGCCCGA CTCTTTCCTA ATAATCTTAA CACCAGCTTT ATGgCTTTGA TGCAACATAT CTCGAAAATC CCCCAAGTGg CAAAgGTTTG GAAGAAGGAT GTGGCTGATG CTTTCAATGA TCCCCGGTTT TTCGGGTCGC AACTCGACCT GgTAAAGGGC GGCTGGATGA CTCTTTTGCG GCAATGGGCC TTGGTTGACA AAgACCGACT GTCTGAGATA ATGACTCGCC TAACCCCGCC GGCCACAGCT GGCATAATGT TCGGCGTTGG TGCATCCGCA GCTCGTTTGg ATGCTGATCG TAAAgCCCAA CTAAATCTTC GTCGGATAAG TCTTTTGgTG TTATCTACAg CTGAgGACTA TTTTATCGCA GAGATGCCGg CGCTACTGCA GAAGCTGGAG GATCTTCTTG GAGCTACCGC TTCATCATCT CCATCTTCCG CTACAAGAGC GGAAATCTTC ATGGTCCTCC GAGCACTCAT ACTGAAGAGC ACAACAACCA CGCTGAGCCC ATTCTGGCCG TTAATAAACA GTGAgCTTCA AgAAgCTATT TCAGCTATCT CATCTGGAAA CCAGCAGGAG TTGTACAATC CATATTCTTT GCTCCAGGCC TGCAAGCTTC TGGACACATT GCTTGTTCTT GCGCCTGACG ATTTCCAATT ACTTGAATGG CTCTATGTTA CTGATACTGT CGACGCTATA TACCCCCCAG AgCAATTCGA ACCCACGgCG CTCGCAGATG AgGtATCTCA CAACTTAGgG GTCCGTTGgT CCACGTCATC TGATCCAACC CGAGAATCGA CCAATCTCCA CCATGgCGTA AgGTATCCAg GTCTGGCGgC GgACTGGATA CGTGAAACCG CCAAAGATGA GATTGTCGAT CGAGTTCTCC GGCCATTCTT TGACCAACTC AGCATCCATG CGTTTGAGAG CACCTACAGC ATCAGCAATC CGAACTTGGA AGCATGCCGT GATGATCTGC TGGCAGATTt GTTCAACGAA AGTACCATGG CAAACTAGCC TTCTTCGGCA TATCTTATTT ACGCTAtATG TACTATACGC TAGGAATAAA CACTATACAT TCTTCAAAAA AAAAA 


\section{ANEXO B}

Sequência de aminoácidos deduzida da sequência de nucleotídeos do cDNA correspondente ao gene aco586. Os residuos em negrito e assinalados, representam:

1. linha dupla: sítio de fosforilação por proteina Tirosina Quinase.

2. linha pontilhada: domínio transmembrana.

3. linha contínua: "Ziper de Leucina" hipotético. Residuos grifados com linha dupla são a Serina e as Leucinas que compõe o Zíper.

4. linha ondulada: domínio de transativação.

$S$ E A T T S V A H D Q L $Q$ Q A V S

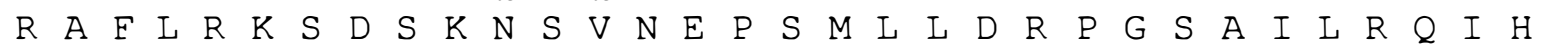

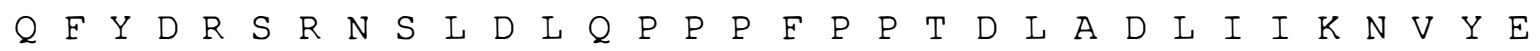

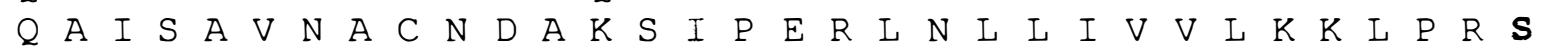

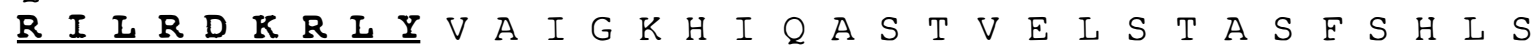
$S$ M S T T I T S L

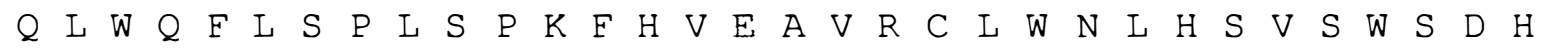

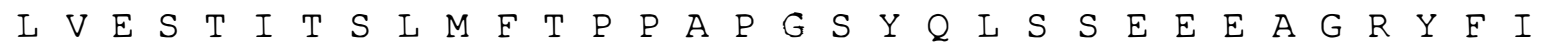

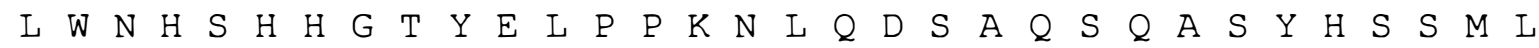

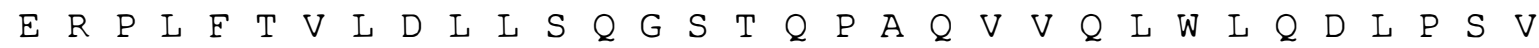

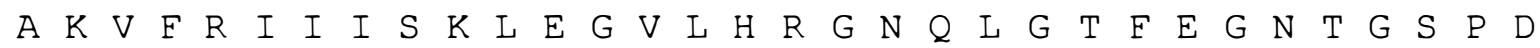

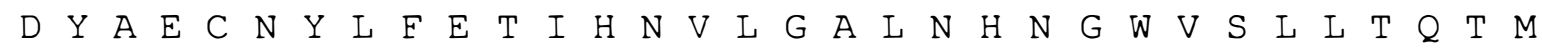
A H

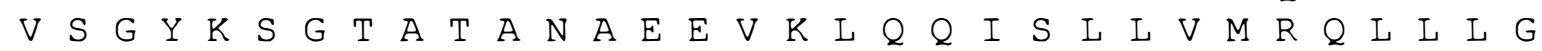

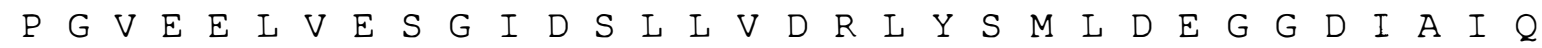
$\begin{array}{llllllllllllllllllllllllllllllll}A & A & L & I & D & T & L & L & A & V & L & K & A & R & F & S & Q & A & Y & L & P & P & P & P & T & K & P & K & H & Q & R & G\end{array}$

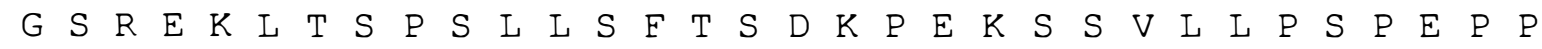
Q R L L L D C L L K K G L S S P R S R A I I D K W I I

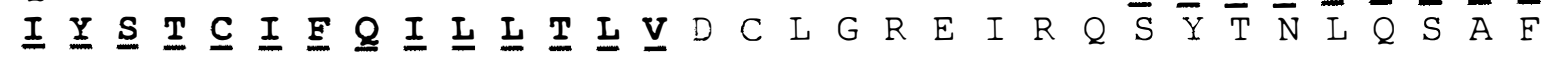

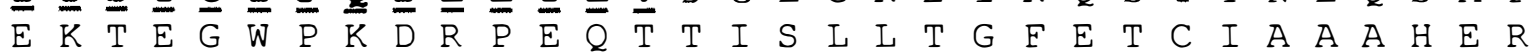

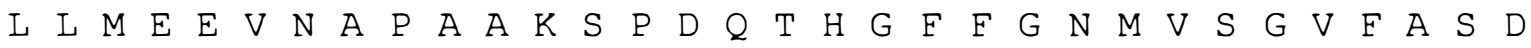
$\begin{array}{llllllllllllllllllllllllllllllll}S & N & H & P & R & S & A & A & M & N & N & R & L & T & V & L & L & S & F & Q & D & A & V & R & L & C & F & S & I & W & S & W\end{array}$

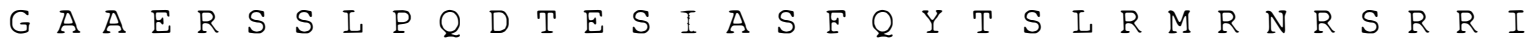

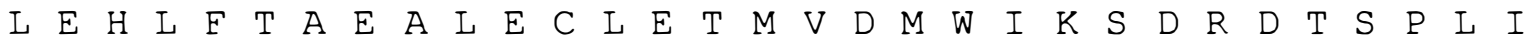


F $N$ L L L

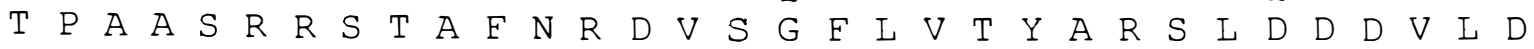

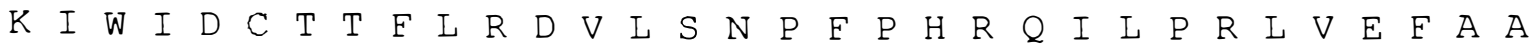

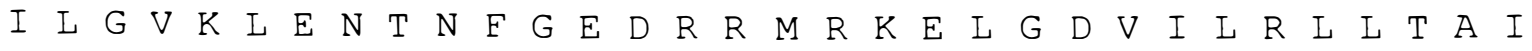

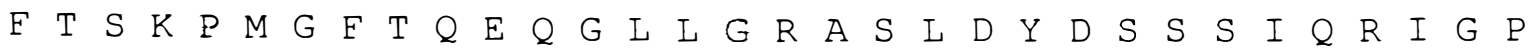
$D$ D M L S I L V A S M P A $F$ S M T L G D M D R I T T A V S $N$

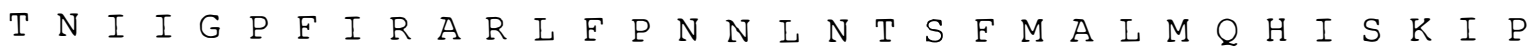
Q $V$ V A K K V V W

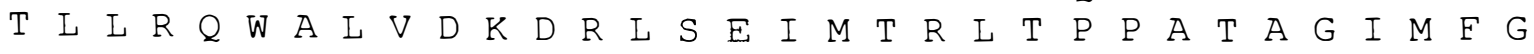
$V$ G A S A A $R$ L $L$

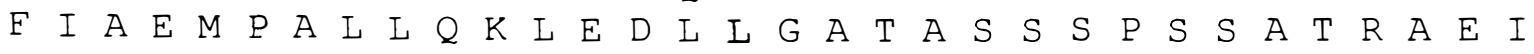

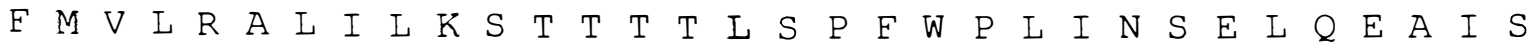

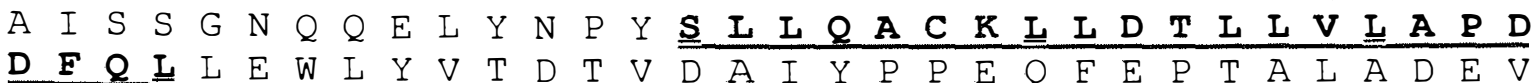
\begin{tabular}{llllllllllllllllllllllllllllllll}
$D$ & $\mathbf{E}$ & $\mathcal{Q}$ & L & $L$ & $E$ & $W$ & $L$ & $Y$ & $V$ & $T$ & $D$ & $T$ & $V$ & $D$ & $A$ & $I$ & $Y$ & $P$ & $P$ & $E$ & $Q$ & $F$ & $E$ & $P$ & $T$ & $A$ & $L$ & $A$ & $D$ & $E$ & $V$ \\
\hline$S$ & $H$ & $N$ & $L$ & $G$ & $V$ & $R$ & $W$ & $S$ & $T$ & $S$ & $S$ & $D$ & $P$ & $T$ & $R$ & $E$ & $S$ & $T$ & $N$ & $L$ & $H$ & $H$ & $G$ & $V$ & $R$ & $Y$ & $P$ & $G$ & $L$ & $A$ & $A$
\end{tabular}

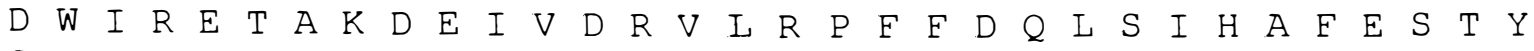
$S$ I S N P N L E A C R D D L L A D L F N E S T M A N 


\section{REFERÊNCIAS BIBLIOGRÁFICAS}

ADAMS, T. H.; TIMBERLAKE, W. E. Developmental repression of growth and gene expression in Aspergillus. Proceedings of the National Academy of Sciences USA, v.87, p.5405-9, 1990a.

ADAMS, T. H.; TIMBERLAKE, W. E. Upstream elements repress premature expression of an Aspergillus developmental regulatory gene. Molecular and Cellular Biology, v.10, p.4912-9, 1990b.

ADAMS, T. H.; DEISING, H.; TIMBERLAKE, W. E. briA requires both zinc fingers to induce development. Molecular and Cellular Biology, v.10, p.1815-7, 1990.

ADAMS, T. H.; HIDE, W. A.; YAGER, L. N.; LEE, B. N. Isolation of a gene required for programmed initiation of development by Aspergillus nidulans. Molecular and Cellular Biology, v.12, p.3827-33, 1992.

ADAMS, T. H.; WIESER, J. K.; YU, J. H. Asexual sporulation in Aspergillus nidulans. Microbiology and Molecular Biology Reviews, v.62, p.35-54, 1998.

ANDRIANOPOULOS, A.; TIMBERLAKE, W. E. The Aspergillus nidulans abaA gene encodes a transcriptional activator that acts as a genetic switch to control development. Molecular and Cellular Biology, v.14, p.2503-15, 1994.

ARAMAYO, R.; PELEG, Y.; ADDISON, R.; METZENBERG, R. Asm-1, a Neurospora crassa gene reealted to transcriptional regulators of fungal development. Genetics, v.144, p.991-1003, 1996.

ARST, H. N., JR.; MACDONALD, D. W. A mutant of Asperigillus nidulans lacking NADP-linked glutamate dehydrogenase. Molecular and General Genetics, v.122, p.261-5, 1973.

AXELROD, D. E. Kinetics of differentiation of conidiophores and conidia by colonies of Aspergillus nidulans. Journal of General Microbiology, v.73, p.181-4, 1972.

AXELROD, D. E.; GEALT, M.; PASTUSHOK, M. Gene control of developmental competence in Aspergillus nidulans. Developmental Biology, v.34, p.9-15, 1973.

BECKWITH, S. M.; ROGHI, C. H.; MORRIS, N. R. The genetics of nuclear migration in fungi. Genetical Engineering, v.17, p.165-80, 1995.

BENJAMIN, C.R. Ascocarps of Aspergillus and Penicillium. Mycologia, v.47, p.669$87,1955$.

BERGEN, L. G.; MORRIS, N. R. Kinetics of the nuclear division cycle of Aspergillus nidulans. Journal of Bacteriology, v.156, p.155-60, 1983. 
BOYLAN, M. T.; MIRABITO, P. M.; WILLETT, C. E.; ZIMMERMAN, C. R.; TIMBERLAKE, W. E. Isolation and physical characterization of three essential conidiation genes from Aspergillus nidulans. Molecular and Cellular Biology, v.7, p.3113-8, 1987.

BRODY, H.; CARBON, J. Eletrophoretic karyotype of Aspergillus nidulans. Proceedings of the National Academy of Science USA, v.86, p.6260-3, 1989.

BUSBY, T. M.; MILLER, K. Y.; MILLER, B. L. Suppression and enhancement of the Aspergillus nidulans medusa mutation by altered dosage of the bristle and stunted genes. Genetics, v.143, p.155-63, 1996.

BUTNICK, N. Z.; YAGER, L. N.; HERMANN, T. E.; KURTZ, M. B.; CHAMPE, S. P. Mutants of Aspergillus nidulans blocked at an early stage of sporulation secrete an unusual metabolite. Journal of Bacteriology, v.160, p.533-40, 1984a.

BUTNICK, N. Z.; YAGER, L. N.; KURTZ, M. B.; CHAMPE, S. P. Genetic analysis of mutants of Aspergillus nidulans blocked at an early stage of sporulation. Journal of Bacteriology, v.160, p.541-5, 1984b.

CHAMPE, S. P.; SIMON, L. D. Cellular differentiation and tissue formation in the fungus Aspergillus nidulans. In: ROSSOMANDO, E.F.; ALEXANDER, S. (Ed.) Morphogenesis, New York: Marcel deker, 1992. Cap.3, p.63-91.

CHAMPE, S. P.; NAGLE, D. L.; YAGER, L. N. Sexual sporulation. Progress in Industrial Microbiology, v.29, p.429-54, 1994.

CHANG, Y. C.; TIMBERLAKE, W. E. Identification of Aspergillus brA response elements (BREs) by genetic selection in yeast. Genetics, v.133, p.29-38, 1993.

CHIU, Y. H.; XIANG, X.; DAWE, A. L.; MORRIS, N. R. Deletion of nudC, a nuclear migration gene of Aspergillus nidulans, causes morphological and cell wall abnormalities and is lethal. Molecular Biology of the Cell, v.8, p.1735-49, 1997.

CLUTTERBUCK, A. J. A mutational a nalysis of conidial development in Aspergillus nidulans. Genetics, v.63, p.317-27, 1969.

CLUTTERBUCK, A. J. Synchronous nuclear division and septation in Aspergillus nidulans. Journal of General Microbiology, v.60, p.133-5, 1970.

CLUTTERBUCK, A.J. Aspergillus nidulans. In: KING, R.C. (Ed.) Handbook of Genetics I. New York, Plenum Press, 1974. cap 7, p. 447-510.

CLUTTERBUCK, A.J. The genetics of conidiation in Aspergillus nidulans. In: SMITH, J.E. \& PATEMAN, J.A. (Eds.) Genetics and Physiology of Aspergillus. London, Academic Press, 1977. cap.12, p. 305-17.

CLUTTERBUCK, A. J. Mutants of Aspergillus nidulans deficient in nuclear migration during hyphal growth and conidiation. Microbiology, v.140, p.1169-74, 1994. 
CONSTANCE, C. M.; MORGAN, J. I. T.; UMEK, R. M. C/EBPalpha regulation of the growth-arrest-associated gene gadd45. Molecular and Cellular Biology, v.16, p.3878-83, 1996.

DAVIDSE, L.C. Benzimidazole fungicides: machanism of action and biological impact. Annual Review of Phytopathology, v.24, p. 43-65, 1986.

DEKKER, J. ; DAVIDSE, L. C. Acquired resistance to benzimidazole derivatives. Environmental Quality and Safe Supplement, v.3, p.410-3, 1975.

DE SOUZA, C. C.; PELLIZZON, C. H.; HIRAISHI, M.; GOLDMAN, M. H.; GOLDMAN, $\mathrm{G}$. $\mathrm{H}$. Isolation and characterisation of cycloheximide-sensitive mutants of Aspergillus nidulans. Current Genetics, v.33, p.60-9, 1998.

DENISON, S. H.; KÄFER, E.; MAY, G. S. Mutation in the bimD gene of Aspergillus nidulans confers a conditional mitotic block and sensitivity to DNA damaging agents. Genetics, v.134, p.1085-96, 1993

DENISON, S. H.; MAY, G. S. Mitotic catastrophe is the mechanism of lethality for mutations that confer mutagen sensitivity in Aspergillus nidulans. Mutation Research, v.304, p.193-202, 1994.

De VRIES, L.; MOUSLI, M.; WURMSER, A.; FARQUHAR, M.G. GAIP, a protein that specifically interacts with the trimeric $G$ protein $G \alpha i 3$, is a member of a protein family with a highly conserved core domain. Proceedings of the National Academy of Science USA, v.92, p.11916-11920, 1995.

DIETZEL, C.; KURJAN, J. Pheromonal regulation and sequence of the Saccharomyces cerevisiae SST2 gene: a model for desensitization to pheromone. Molecular and Cellular Biology, v.7, p.4169-77, 1987.

DOHLMAN, H. G.; APANIESK, D.; CHEN, Y.; SONG, J.; NUSSKERN, D. Inhibition of G-protein signaling by dominant gain-of-function mutations in $S s t 2 p$, a pheromone desensitization factor in Saccharomyces cerevisiae. Molecular and Cellular Biology, v.15, p.3635-43, 1995.

DOONAN, J.H. Cell division in Aspergillus. Journal of Cell Science, v.103, p.599$611,1992$.

DOONAN, J. H.; MORRIS, N. R. The bimG gene of Aspergillus nidulans, required for completion of anaphase, encodes a homolog of mammalian phosphoprotein phosphatase 1. Cell, v.57, p.987-96, 1989.

DOONAN, J. H.; MACKINTOSH, C.; OSMANI, S.; COHEN, P.; BAI, G. A cDNA encoding rabbit muscle protein phosphatase 1 alpha complements the Aspergillus cell cycle mutation, bimG11. Journal of Biological Chemistry, v.266, p.1888994, 1991. 
DORN, G. L. Genetic and morphological properties of undifferentiated and invasive variants of Aspergillus nidulans. Genetics, v.66, p.267-79, 1970.

DOSHI, P.; BOSSIE, C. A.; DOONAN, J. H.; MAY, G. S.; MORRIS, N. R. Two alphatubulin genes of Aspergillus nidulans encode divergent proteins. Molecular and General Genetics, v.225, p.129-41, 1991.

DUTTON, J. R.; JOHNS, S.; MILLER, B. L. StuAp is a sequence-specific transcription factor that regulates developmental complexity in Aspergillus nidulans. EMBO Journal, v.16, p.5710-21, 1997.

EFIMOV, V. P.; MORRIS, N. R. A screen for dynein synthetic lethals in Aspergillus nidulans identifies spindle assembly checkpoint genes and other genes involved in mitosis. Genetics, v.149, p.101-16, 1998.

ENGLE, D. B.; OSMANI, S. A.; OSMANI, A. H.; ROSBOROUGH, S.; XIN, X. N. A negative regulator of mitosis in Aspergillus is a putative membrane- spanning protein. Journal of Biological Chemistry, v.265, p.16132-7, 1990.

ENOS, A. P.; MORRIS, N. R. Mutation of a gene that encodes a kinesin-like protein blocks nuclear division in A. nidulans. Cell, v.60, p.1019-27, 1990.

ENOS, A. P.; O'CONNELL, M.; MORRIS, N. R. Kinesin-like proteins of Aspergillus nidulans. Cold Spring Harbor Symposium in Quantitative Biology, v.56, p.6438, 1991.

EVANS, R.M.; HOLLENBERG, S.M. Zinc finger: gilt by association. Cell, v.52, p.1-3, 1988.

FIDDY, C.; TRINCI, A. P. Mitosis, septation, branching and the duplication cycle in Aspergillus nidulans. Journal of General Microbiology, v.97, p.169-84, 1976.

FISCHER, R.; TIMBERLAKE, W. E. Aspergillus nidulans apsA (anucleate primary sterigmata) encodes a coiled-coil protein required for nuclear positioning and completion of asexual development. Journal of Cell Biology, v.128, p.485-98, 1995.

FOLLetTe, P. J.; O'FARRELL, P. H. Cdks and the Drosophila cell cycle. Current Opinion in Genetics and Development, v.7, p.17-22, 1997 a.

FOLLETTE, P. J.; O'FARRELL, P. H. Connecting cell behavior to patterning: lessons from the cell cycle. Cell, v.88, p.309-14, 1997b.

FOREMAN, P. K.; DAVIS, R. W. CDP1, a novel Saccharomyces cerevisiae gene required for proper nuclear division and chromosome segregation. Genetics, v.144, p.1387-97, 1996. 
FORSBURG, S. L.; NURSE, P. Cell cycle regulation in the yeasts Saccharomyces cerevisiae and Scchizossacharomyces pombe. Annual Review in Cell Biology, v.7, p.227-56, 1991.

GIMENO, C. J.; FINK, G. R. Induction of pseudohyphal growth by overexpression of PHD1, a Saccharomyces cerevisiae gene related to transcriptional regulators of fungal development. Molecular and Cellular Biology, v.14, p.2100-12, 1994.

GIMENO, C. J.; LJUNGDAHL, P. O.;STYLES, C. A.; FINK, G. R. Unipolar cell divisions in the yeast $S$. cerevisiae lead to filamentous growth: regulation by starvation and RAS. Cell, v.68, p.1077-90, 1992.

GOLDMAN, G. H.; MORRIS, N. R. Extragenic suppressors of a dynein mutation that blocks nuclear migration in Aspergillus nidulans. Genetics, v.139, p.1223-32, 1995.

GOODAY, G.W. The hyphal tip. In: Smith, J.E. Fungal Differentiation. A Contemporary Synthesis. New York, Dekker, 1983. p. 315-56.

HAIR, A.; PRIOLEAU, M. N.; VASSETZKY, Y.; MECHALI, M. Control of gene expression in Xenopus early development. Developmental Genetics, v.22, p.12231, 1998.

HAMER, L. From genes to genomes: Sequencing of filamentous fungal genomes. Fungal Genetics and Biology, v. 21, p. 8-10, 1997.

HAN, S.; NAVARRO, J.; GREVE, R. A.; ADAMS, T. H. Translational repression of brlA expression prevents premature development in Aspergillus. EMBO Journal, v.12, p.2449-57, 1993.

HARRIS, S. D. The duplication cycle in Aspergillus nidulans. Fungal Genetics and Biology, v.22, p.1-12, 1997.

HARRIS, S. D.; MORRELL, J. L.; HAMER, J. E. Identification and characterization of Aspergillus nidulans mutants defective in cytokinesis. Genetics, v.136, p.517-32, 1994.

HARRIS, S. D.; HAMER, J. E. sepB: an Aspergillus nidulans gene involved in chromosome segregation and the initiation of cytokinesis. EMBO Journal, v.14, p.5244-57, 1995.

HARRIS, S. D.; HAMER, L.; SHARPLESS, K. E.; HAMER, J. E. The Aspergillus nidulans sepA gene encodes an $\mathrm{FH} 1 / 2$ protein involved in cytokinesis and the maintenance of cellular polarity. EMBO Journal, v.16, p.3474-83, 1997.

HARRIS, S. D.; KRAUS, P. R. Regulation of septum formation in Aspergillus nidulans by a DNA damage checkpoint pathway. Genetics, v.148, p.1055-67, 1998. 
HARTWELL, L. H. Saccharomyces cerevisiae cell cycle. Bacteriology Reviews, v.38, p.164-98, 1974.

HARTWELL, L. H.; KASTAN, M. B. Cell cycle control and cancer. Science, v.266, p.1821-8, 1994.

HASSON, M. S.; BLINDER, D.; THORNER, J.; JENNESS, D. D. Mutational activation of the STE5 gene product bypasses the requirement for $G$ protein beta and gamma subunits in the yeast pheromone response pathway. Molecular and Cellular Biology, v.14, p.1054-65, 1994.

HICKS, J. K.; YU, J. H.; KELLER, N. P.; ADAMS, T. H. Aspergillus sporulation and mycotoxin production both require inactivation of the FadA $G$ alpha proteindependent signaling pathway. EMBO Journal, v.16, p.4916-23, 1997.

HIROKAWA, $N$. Kinesin and dynein superfamily proteins and the mechanism of organelle transport. Science, v.279, p.519-26, 1998.

HOLT, C. L.; MAY, G. S. An extragenic suppressor of the mitosis-defective bimD6 mutation of Aspergillus nidulans codes for a chromosome scaffold protein. Genetics, v.142, p.777-87, 1996.

IRNIGER, S.; NASMYTH, K. The anaphase-promoting complex is required in G1 arrested yeast cells to inhibit B-type cyclin accumulation and to prevent uncontrolled entry into S-phase. Journal of Cell Science, v.110, p.1523-31, 1997.

JACOBS, T. Control of the cell cycle. Developmental Biology, v.153, p.1-15, 1992.

JOHNSTONE, I. L.; HUGHES, S. G.; CLUTTERBUCK, A. J. Cloning an Aspergillus nidulans developmental gene by transformation. EMBO Journal, v.4, p.1307-11, 1985.

JUANG, Y. L.; HUANG, J.; PETERS, J. M.; MCLAUGHLIN, M. E.; TAI, C. Y. APCmediated proteolysis of Ase1 and the morphogenesis of the mitotic spindle. Science, v.275, p.1311-4, 1997.

KAFER, E. Origens of translocations in Aspergillus nidulans. Genetics, v52, p. 217-32, 1965.

KÄFER, E. Meiotic and mitotic recombination in Aspergillus and its chromosomal aberrations. Advances in Genetics, v.19, p.33-131, 1977.

KAMINSKYJ, S. G.; HAMER, J. E. hyp loci control cell pattern formation in the vegetative mycelium of Aspergillus nidulans. Genetics, v.148, p.669-80, 1998.

KIRK, K. E.; MORRIS, N. R. The tubB alpha-tubulin gene is essential for sexual development in Aspergillus nidulans. Genes and Development, v.5, p.2014-23, 1991. 
$\mathrm{KOCH}, \mathrm{C}$.; NASMYTH, K. Cell cycle regulated transcription in yeast. Current Opinion in Cell Biology, v.6, p.451-9, 1994.

KOPAN, R.; TURNER, D. L. The Notch pathway: democracy and aristocracy in the selection of cell fate. Current Opinion in Neurobiology, v.6, p.594-601, 1996.

KRON, S. J.; GOW, N. A. Budding yeast morphogenesis: signalling, cytoskeleton and cell cycle. Current Opinion in Cell Biology, v.7, p.845-55, 1995.

KRUGER, M.; FISCHER, R. Integrity of a Zn finger-like domain in SamB is crucial for morphogenesis in ascomycetous fungi. EMBO Journal, v.17, p.204-14, 1998.

LEE, B. N.; ADAMS, T. H. The Aspergillus nidulans fluG gene is required for production of an extracellular developmental signal and is related to prokaryotic glutamine synthetase I. Genes and Development, v.8, p.641-51, 1994a.

LEE, B. N.; ADAMS, T. H. Overexpression of flbA, an early regulator of Aspergillus asexual sporulation, leads to activation of brlA and premature initiation of development. Molecular Microbiology, v.14, p.323-34, 1994b.

LEW, D. J.; KORNBLUTH, S. Regulatory roles of cyclin dependent kinase phosphorylation in cell cycle control. Current Opinion in Cell Biology, v.8, p.795804, 1996.

LIES, C. M.; CHENG, J.; JAMES, S. W.; MORRIS, N. R.; O'CONNELL, M. J. BIMAAPC3, a component of the Aspergillus anaphase promoting complex/cyclosome, is required for a G2 checkpoint blocking entry into mitosis in the absence of NIMA function. Journal of Cell Science, v.111, p.1453-65, 1998.

LUSCHER, B.; EISENMAN, R. N. New light on Myc and Myb. Part I. Myc. Genes and Development, v.4, p.2025-35, 1990.

MAGEE, P. T. Which came first, the hypha or the yeast? Science, v.277, p.52-3, 1997.

MAJELLO, B.; KENYON, L. C.; DALLA-FAVERA, R. Human c-myb protooncogene: nucleotide sequence of CDNA and organization of the genomic locus. Proceedings of the National Academy of Sciences, USA, v.83, p.9636-40, 1986.

MARHOUL, J.; ADAMS, T. H. Isolation of Aspergillus nidulans mutants that overcome $b r A$-induced growth arrest. Fungal Genetics and Biology, v.21, p.109-17, 1996

MATA, J.; NURSE, P. tea1 and the microtubular cytoskeleton are important for generating global spatial order within the fission yeast cell. Cell, v.89, p.939-49, 1997. 
MARTINELLI, S.D. \& CLUTTERBUCK, A.J. A quantitative survey of conidiation mutants in Aspergillus nidulans. Journal of General Microbiology, v. 69, p.2618, 1971.

MARTINELLI, S.D. Phenotypes of double conidiation mutants of Aspergillus nidulans. Journal of General Microbiology, v.144, p.277-87, 1979.

MAY, G. S.; GAMBINO, J.; WEATHERBEE, J. A.; MORRIS, N. R. Identification and functional analysis of beta-tubulin genes by site specific integrative transformation in Aspergillus nidulans. Journal of Cell Biology, v.101, p.712-9, 1985.

MAY, G. S.; MORRIS, N. R. Developmental regulation of a conidiation specific betatubulin in Aspergillus nidulans. Developmental Biology, v.128, p.406-14, 1988.

MAY, G. S.; TSANG, M. L.; SMITH, H.; FIDEL, S.; MORRIS, N. R. Aspergillus nidulans beta-tubulin genes are unusually divergent. Gene, v.55, p.231-43, 1987.

MCGOLDRICK, C. A.; GRUVER, C.; MAY, G. S. myoA of Aspergillus nidulans encodes an essential myosin I required for secretion and polarized growth. Journal of Cell Biology, v.128, p.577-87, 1995.

MCKNIGHT, S.L. Transcription revisited: A commentary on the 1995 Cold Spring Harbor Laboratory meeting, "Mechanisms of Eukaryotic transcription". Genes and Development, v.10, p.367-381, 1995.

MEYEROWITZ, E. M. Genetic control of cell division patterns in developing plants. Cell, v.88, p.299-308, 1997.

MILLER, B.L. The developmental genetics of asexual reproduction in Aspergillus nidulans. Seminars in Developmental Biology, v.1, p.207-19, 1990.

MILLER, K. Y.; TOENNIS, T. M.; ADAMS, T. H.; MILLER, B. L. Isolation and transcriptional characterization of a morphological modifier: the Aspergillus nidulans stunted (stuA) gene. Molecular and General Genetics, v.227, p.285-92, 1991.

MILLER, K. Y.; WU, J.; MILLER, B. L. StuA is required for cell pattern formation in Aspergillus. Genes and Development, v.6, p.1770-82, 1992.

MILLER, B. L. Brushing up on bristles: complex genes and morphogenesis in molds. Trends in Genetics, v.9, p.293-5, 1993.

MIRABITO, P. M.; ADAMS, T. H.; TIMBERLAKE, W. E. Interactions of three sequentially expressed genes control temporal and spatial specificity in Aspergillus development. Cell, v.57, p.859-68, 1989.

MIRABITO, P. M.; OSMANI, S.A. Interactions between the developmental program and cell cycle regulation of Aspergillus nidulans. Seminars in Developmental Biology, v.5, p. 139-45, 1994. 
MOONEY, J. L.; HASSETT, D. E.; YAGER, L. N. Genetic analysis of suppressors of the veA1 mutation in Aspergillus nidulans. Genetics, v.126, p.869-74, 1990.

MOONEY, J. L.; YAGER, L. N. Light is required for conidiation in Aspergillus nidulans. Genes and Development, v.4, p.1473-82, 1990.

MORRIS, N.R. Mitotic mutants of Aspergillus nidulans. Genetical Research, v.26, p.237-57, 1976.

MORRIS, R. N.; ENOS, A. P. Mitotic gold in a mold: Aspergillus genetics and biology of mitosis. Trends in Genetics, v. 8, p. 32-7, 1992.

MORRIS, N. R.; OSMANI, S. A.; ENGLE, D. B.; DOONAN, J. H. The genetic analysis of mitosis in Aspergillus nidulans. Bioessays, v.10, p.196-201, 1989.

MORRIS, S. M.; ANAYA, P.; XIANG, X.; MORRIS, N. R.; MAY, G. S. A prolactininducible $T$ cell gene product is structurally similar to the Aspergillus nidulans nuclear movement protein NUDC. Molecular Endocrinology, v.11, p.229-36, 1997.

NASMYTH, K. Evolution of the cell cycle. Philosophical Transaction of the Royal Society of London Series B- Biological Sciences, v.349, p.271-81, 1995.

NASMYTH, K. At the heart of the budding yeast cell cycle. Trends in Genetics, v.12, p.405-12, 1996.

NURSE, P. Genetic control of cell size at cell division in yeast. Nature, v.256, p.457$51,1975$.

OAKLEY, B. R.; OAKLEY, C. E.; YOON, Y.; JUNG, M. K. Gamma-tubulin is a component of the spindle pole body that is essential for microtubule function in Aspergillus nidulans. Cell, v.61, p.1289-301, 1990.

OAKLEY, C. E.; OAKLEY, B. R. Identification of gamma-tubulin, a new member of the tubulin superfamily encoded by mip $A$ gene of Aspergillus nidulans. Nature, v.338, p.662-4, 1989.

O'CONNELL, M. J.; OSMANI, A. H.; MORRIS, N. R.; OSMANI, S. A. An extra copy of nimEcyclinB elevates pre-MPF levels and partially suppresses mutation of nimTcdc25 in Aspergillus nidulans. EMBO Journal, v.11, p.2139-49, 1992.

ODDS, F. C. Activity of cilofungin (LY121019) against Candida species in vitro. Journal of Antimicrobial Chemotherapy, v.22, p.891-7, 1988.

O'DONNELL, K. L.; OSMANI, A. H.; OSMANI, S. A.; MORRIS, N. R. bimA encodes a member of the tetratricopeptide repeat family of proteins and is required for the completion of mitosis in Aspergillus nidulans. Journal of Cell Science, v.99, p.711-9, 1991. 
OSMANI, S. A.; MAY, G. S.; MORRIS, N. R. Regulation of the mRNA levels of nimA, a gene required for the G2-M transition in Aspergillus nidulans. Journal of Cell Biology, v.104, p.1495-504, 1987.

OSMANI, A. H.; OSMANI, S. A.; MORRIS, N. R. The molecular cloning and identification of a gene product specifically required for nuclear movement in Aspergillus nidulans. Journal of Cell Biology, v.111, p.543-51, 1990.

OSMANI, A. H.; MCGUIRE, S. L.; OSMANI, S. A. Parallel activation of the NIMA and p34cdc2 cell cycle-regulated protein kinases is required to initiate mitosis in $A$. nidulans. Cell, v.67, p.283-91, 1991.

OSMANI, A. H.; VAN PEIJ, N.; MISCHKE, M.; O'CONNELL, M. J.; OSMANI, S. A. A single $p 34 c d c 2$ protein kinase (encoded by nimXcdc2) is required at $\mathrm{G} 1$ and $\mathrm{G} 2$ in Aspergillus nidulans. Journal of Cell Science, v.107, p.1519-28, 1994.

OSMANI, S. A.; YE, X. S. Cell cycle regulation in Aspergillus by two protein kinases. Biochemistry Journal, v.317, p.633-41, 1996.

PASCON, R. C. Isolamento e caracterização de setores deteriorados da linhagem AbncA1 de Aspergillus nidulans. Piracicaba, 1994. 123p. Dissertação (Ms) Escola Superior de Agriculatura "Luiz de Queiróz", Universidade de São Paulo.

PASTUSHOK, M.; AXELROD, D. E. Effect of glucose, ammonium and media maintenance on the time of conidiophore initiation by surface colonies of Aspergillus nidulans. Journal of General Microbiology, v.94, p.221-4, 1976.

PELLMAN, D.; BAGGET, M.; TU, Y. H.; FINK, G. R.; TU, H. Two microtubuleassociated proteins required for anaphase spindle movement in Saccharomyces cerevisiae. Journal of Cell Biology, v.130, p.1373-85, 1995.

PENNISI, E. Cell division gatekeepers identified. Science, v.279, p.477-8, 1998.

PIZZIRANI-KLEINER, A.A.; AZEVEDO, J.L. Characterization and genetical analysis of an Aspergillus nidulans strain that produces multinucleate conidia. Transaction of the British Mycological Society, v.86, p.123-30, 1986.

PRADE, R. A.; TIMBERLAKE, W. E. The Aspergillus nidulans briA regulatory locus consists of overlapping transcription units that are individually required for conidiophore development. EMBO Journal, v.12, p.2439-47, 1993.

PONTECORVO, G.; ROPER, J.A.; HEMMONS, L.M.; MCDONALD, K.D.; BUFTON, A.W.J. The genetics of Aspergillus nidulans. Advances in Genetics, v.5, p.141238, 1953.

PONTECORVO, G.; TARR-GLOOR, E.; FORBES, E. Analysis of mitotic recombination in Aspergillus nidulans. Journal of Genetics, v.52, p.226-37, 1954. 
PTASHNE, M. A genetic switch. Cambridge: Blackwell Scientific Publications \& Cell Press, 1992. 192p.

PU, R. T.; OSMANI, S. A. Mitotic destruction of the cell cycle regulated NIMA protein kinase of Aspergillus nidulans is required for mitotic exit. EMBO Journal, v.14, p.995-1003, 1995.

RAEDER, U.; BRODA, P., Comparison of the lignin-degrading white rot fungi Phanerochaete chrysosporium and Sporotrichum pulverulentum at the DNA level. Current Genetics, v.8,p.499-506, 1985.

RASMUSSEN, C. D.; MEANS, R. L.; LU, K. P.; MAY, G. S.; MEANS, A. R. Characterization and expression of the unique calmodulin gene of Aspergillus nidulans. Journal of Biological Chemistry, v.265, p.13767-75, 1990.

ROBERTS, C.F. A replica plating technique for the isolation of nutritionally exacting mutants of a filamentous fungus (Aspergillus nidulans). Journal of General Microbiology, v.20, p.540-8, 1959.

ROPER, J.A. Production of heterozygous diploids in filamentous fungi. Experientia, v.8, p.14-5, 1952.

ROSENBERGER, R. F.; KESSEL, M. Synchrony of nuclear replication in individual hyphae of Aspergillus nidulans. Journal of Bacteriology, v.94, p.1464-9, 1967.

SAMBROOK, J.;FRITSCH, E.F.; MANIATIS, T. Molecular cloning: a laboratory manual. 2ed. New York: Cold Spring Harbor Laboratory Press, 1989. v.3.

SCHROETER, E. H.; KISSLINGER, J. A.; KOPAN, R. Notch-1 signalling requires ligand-induced proteolytic release of intracellular domain. Nature, v.393, p.382-6, 1998.

SPRINGER, M. L. Genetic control of fungal differentiation: the three sporulation pathways of Neurospora crassa. Bioessays, v.15, p.365-74, 1993.

STOLDT, V. R.; SONNEBORN, A.; LEUKER, C. E.; ERNST, J. F. Efg1p, an essential regulator of morphogenesis of the human pathogen Candida albicans, is a member of a conserved class of bHLH proteins regulating morphogenetic processes in fungi. EMBO Journal, v.16, p.1982-91, 1997.

TAMAME, M.; ANTEQUERA, F.; VILLANUEVA, J. R.; SANTOS, T. High-frequency conversion to a "fluffy" developmental phenotype in Aspergillus spp. by 5azacytidine treatment: evidence for involvement of a single nuclear gene. Molecular and Cellular Biology, v.3, p.2287-97, 1983.

TIMBERLAKE, W. E. Developmental gene regulation in Aspergillus nidulans. Developmental Biology, v.78, p.497-510, 1980. 
TIMBERLAKE, W. E. Molecular genetics of Aspergillus development. Annual Review in Genetics, v.24, p.5-36, 1990.

TIMBERLAKE, W. E.; CLUTTERBUCK, A. J. Genetic regulation of conidiation. Progress in industrial Microbiology, v.29, p.383-427, 1994.

TIMBERLAKE, W. E.; MARSHALL, M. A. Genetic regulation of development in Aspergillus nidulans. Trends in Genetics, v.4, p.162-9, 1988.

UMEK, R. M.; FRIEDMAN, A. D.; MCKNIGHT, S. L. CCAAT-enhancer binding protein: a component of a differentiation switch. Science, v.251, p.288-92, 1991.

UPSHALL, A. Genetic and molecular characterization of $\arg ^{+}$transformants of Aspergillus nidulans. Current Genetics, v. 10, p.593-9, 1986.

WANG, X. Z.; RON, D. Stress-induced phosphorylation and activation of the transcription factor CHOP (GADD153) by p38 MAP Kinase. Science, v.272, p.1347-9, 1996.

WEDEL, A.; ZIEGLER-HEITBROCK, H. W. The C/EBP family of transcription factors. Immunobiology, v.193, p.171-85, 1995.

WEIL, C. F.; OAKLEY, C. E.; OAKLEY, B. R. Isolation of mip (microtubule-interacting protein) mutations of Aspergillus nidulans. Molecular and Cellular Biology, v.6, p.2963-8, 1986.

WEINMASTER, G. The ins and outs of notch signaling. Molecular and Cellular Neuroscience, v.9, p.91-102, 1997.

WIESER, J.; ADAMS, T. H. flbD encodes a Myb-like DNA-binding protein that coordinates initiation of Aspergillus nidulans conidiophore development. Genes and Development, v.9, p.491-502, 1995.

WIESER, J.; LEE, B. N.; FONDON, J.; ADAMS, T. H. Genetic requirements for initiating asexual development in Aspergillus nidulans. Current Genetics, v.27, p.62-9, 1994.

WOLKOW, T. D.; HARRIS, S. D.; HAMER, J. E. Cytokinesis in Aspergillus nidulans is controlled by cell size, nuclear positioning and mitosis. Journal of Cell Science, v.109, p.2179-88, 1996.

WU, J.; MILLER, B. L. Aspergillus asexual reproduction and sexual reproduction are differentially affected by transcriptional and translational mechanisms regulating stunted gene expression. Molecular and Cellular Biology, v.17, p.6191-201, 1997.

XIANG, X.; BECKWITH, S. M.; MORRIS, N. R. Cytoplasmic dynein is involved in nuclear migration in Aspergillus nidulans. Proceedings of the National Academy of Sciences, USA, v.91, p.2100-4, 1994. 
XIANG, X.; OSMANI, A. H.; OSMANI, S. A.; ROGHI, C. H.; WILLINS, D. A. Analysis of nuclear migration in Aspergillus nidulans. Cold Spring Harbor Symposium in Quantitative Biology, v.60, p.813-9, 1995a.

XIANG, X.; OSMANI, A. H.; OSMANI, S. A.; XIN, M.; MORRIS, N. R. NudF, a nuclear migration gene in Aspergillus nidulans, is similar to the human LIS-1 gene required for neuronal migration. Molecular Biology of the Cell, v.6, p.297-310, 1995b.

XIONG, M.; CHEN, H. J.; PRADE, R. A.; WANG, Y.; GRIFFITH, J. On the consistency of a physical mapping method to reconstruct a chromosome in vitro. Genetics, v.142, p.267-84, 1996.

YAGER, L. N.; KURTZ, M. B.; CHAMPE, S. P. Temperature-shift analysis of conidial development in Aspergillus nidulans. Developmental Biology, v.93, p.92-103, 1982.

YE, X. S.; XU, G.; PU, R. T.; FINCHER, R. R.; MCGUIRE, S. L. The NIMA protein kinase is hyperphosphorylated and activated downstream of $p 34 c d c 2 / c y c l i n ~ B$ : coordination of two mitosis promoting kinases. EMBO Journal, v.14, p.986-94, 1995.

YU, J. H.; WIESER, J.; ADAMS, T. H. The Aspergillus RGS domain protein antagonizes $G$ protein signaling to block proliferation and allow development. EMBO Journal, v.15, p.5184-90, 1996.

YUILL, E. Two new Aspergillus mutants. Journal of Botany, v.77, p.174-5, 1939.

ZACHARIAE, W.; NASMYTH, K. TPR proteins required for anaphase progression mediate ubiquitination of mitotic B-type cyclins in yeast. Molecular Biology of the Cell, v.7, p.791-801, 1996. 


\section{APÊNDICE}

A tabela mostra os dados usados na construção do gráfico da Figura 2.

\begin{tabular}{|c|c|c|c|c|c|c|c|c|c|c|c|c|}
\hline \multirow[t]{2}{*}{ Tempos } & \multirow[t]{2}{*}{ Linhagens } & \multicolumn{11}{|c|}{ Número de núcleos por germi nante } \\
\hline & & 1 & 2 & 3 & 4 & 6 & 8 & 10 & 12 & 14 & 16 & Total \\
\hline \multirow{5}{*}{ O horas } & UI 201 & 143 & - & - & - & - & - & - & - & - & - & 143 \\
\hline & & 100 & - & - & - & - & - & - & - & - & - & - \\
\hline & & $\%$ & & & & & & & & & & \\
\hline & UI 203 & 106 & 27 & 4 & - & - & - & - & - & - & - & 137 \\
\hline & & $77 \%$ & $20 \%$ & $3 \%$ & - & - & - & - & - & - & - & - \\
\hline \multirow{5}{*}{2 horas } & UI 201 & 113 & - & - & - & - & - & - & - & - & - & 113 \\
\hline & & 100 & - & - & - & - & - & - & - & - & - & - \\
\hline & & $\%$ & & & & & & & & & & \\
\hline & UI 203 & 109 & 24 & 4 & - & - & - & - & - & - & - & 137 \\
\hline & & $80 \%$ & $17 \%$ & $3 \%$ & - & - & - & - & - & - & - & - \\
\hline \multirow{4}{*}{4 horas } & UI 201 & 48 & 111 & - & - & - & - & - & - & - & - & 159 \\
\hline & & $30 \%$ & $70 \%$ & - & - & - & - & - & - & - & - & - \\
\hline & UI $20 \overline{3}$ & 10 & 67 & 9 & 77 & 5 & 20 & - & - & - & - & 188 \\
\hline & & $5 \%$ & $35 \%$ & $5 \%$ & $41 \%$ & $3 \%$ & $11 \%$ & - & - & - & - & - \\
\hline \multirow{4}{*}{5 horas } & UI 201 & - & 35 & - & 84 & - & 5 & - & - & - & - & 124 \\
\hline & & - & $28 \%$ & - & $68 \%$ & - & $4 \%$ & - & - & - & - & - \\
\hline & UI 203 & - & 4 & - & 43 & 13 & 67 & - & 5 & - & 4 & 136 \\
\hline & & - & $3 \%$ & - & $31 \%$ & $9 \%$ & $50 \%$ & - & $4 \%$ & - & $3 \%$ & - \\
\hline \multirow{4}{*}{6 horas } & UI 201 & - & - & - & 12 & - & 129 & - & - & - & 7 & 148 \\
\hline & & - & - & - & $8 \%$ & - & $87 \%$ & - & - & - & $5 \%$ & - \\
\hline & UI 203 & - & - & - & 2 & - & 56 & 5 & 12 & 8 & $\overline{87}$ & 170 \\
\hline & & - & - & - & $1 \%$ & - & $33 \%$ & $3 \%$ & $7 \%$ & $5 \%$ & $51 \%$ & - \\
\hline
\end{tabular}


A tabela abaixo contém os dados utilizados para construir o gráfico da Figura 8.

\begin{tabular}{|c|c|c|}
\hline Horas & $\Delta a c 0586.17$ & FGSC26 \\
\hline & $\overline{0}$ & $4 \times 10^{4}$ \\
\hline \multirow[t]{2}{*}{24} & 0 & $5 \times 10^{4}$ \\
\hline & 0 & $3 \times 10^{4}$ \\
\hline \multirow[t]{2}{*}{ Média } & 0 & $4 \times 10^{4}$ \\
\hline & $5 \times 10^{5}$ & $1,4 \times 10^{-}$ \\
\hline \multirow[t]{2}{*}{48} & $3 \times 10^{5}$ & $0,7 \times 10^{7}$ \\
\hline & $2,5 \times 10^{5}$ & $0,9 \times 10^{7}$ \\
\hline \multirow[t]{2}{*}{ Média } & $3,5 \times 10^{5}$ & $1 \times 107$ \\
\hline & $1 \times 10^{6}$ & $4,4 \times 10^{-}$ \\
\hline \multirow[t]{2}{*}{72} & $1,3 \times 10^{6}$ & $3,6 \times 10^{7}$ \\
\hline & $2,2 \times 10^{6}$ & $2,5 \times 10^{7}$ \\
\hline \multirow[t]{2}{*}{ Média } & $1,5 \times 10^{6}$ & $3,5 \times 10^{7}$ \\
\hline & $2,8 \times 10^{6}$ & $6,7 \times 10^{7}$ \\
\hline \multirow[t]{2}{*}{96} & $5 \times 10^{6}$ & $5,4 \times 10^{7}$ \\
\hline & $7,2 \times 10^{6}$ & $6,5 \times 10^{7}$ \\
\hline \multirow[t]{2}{*}{ Média } & $5 \times 10^{6}$ & $6,2 \times 10^{7}$ \\
\hline & $1 \times 10^{7}$ & $7,3 \times 10^{7}$ \\
\hline \multirow[t]{2}{*}{120} & $1,3 \times 10^{7}$ & $6,2 \times 10^{7}$ \\
\hline & $0,7 \times 10^{7}$ & $10,5 \times 10^{7}$ \\
\hline \multirow[t]{2}{*}{ Média } & $1 \times 10^{7}$ & $8 \times 10^{7}$ \\
\hline & $0,98 \times 10^{7}$ & $1,07 \times 10^{8}$ \\
\hline \multirow[t]{2}{*}{144} & $1,03 \times 10^{7}$ & $1,28 \times 10^{8}$ \\
\hline & $1,59 \times 10^{7}$ & $1,28 \times 10^{8}$ \\
\hline Média & $1,2 \times 10^{-}$ & $1,21 \times 10^{8}$ \\
\hline
\end{tabular}

